NBER WORKING PAPER SERIES

\title{
HOW DO BUDGET DEFICITS AND ECONOMIC \\ GROWTH AFFECT REELECTION PROSPECTS? \\ EVIDENCE FROM A LARGE CROSS-SECTION OF COUNTRIES
}

\author{
Adi Brender \\ Allan Drazen \\ Working Paper 11862 \\ http://www.nber.org/papers/w11862 \\ NATIONAL BUREAU OF ECONOMIC RESEARCH \\ 1050 Massachusetts Avenue \\ Cambridge, MA 02138 \\ December 2005
}

We wish to thank Mark Duggan for useful comments and Amir Marchak, Lior Gallo and Sagie Dagan for superb research assistance. Drazen wishes to thank the Israel Science Foundation, the National Science Foundation, grant 418412, and the Yael Chair in Comparative Economics, Tel Aviv University for financial support, as well as the Research Department of the Bank of Israel for its hospitality. The views expressed in the paper do not necessarily reflect those of the Bank of Israel. The views expressed herein are those of the author(s) and do not necessarily reflect the views of the National Bureau of Economic Research.

(C)2005 by Adi Brender and Allan Drazen. All rights reserved. Short sections of text, not to exceed two paragraphs, may be quoted without explicit permission provided that full credit, including $\odot$ notice, is given to the source. 
How Do Budget Defecits and Economic Growth Affect Reelection Prospects? Evidence from a Large Cross-Section of Countries

Adi Brender and Allan Drazen

NBER Working Paper No. 11862

December 2005

JEL No. D72, E62, H62

\begin{abstract}
$\underline{\text { ABSTRACT }}$
Conventional wisdom is that good economic conditions or expansionary fiscal policy help incumbents get re-elected, but this has not been tested in a large cross-section of countries. We test these arguments in a sample of 74 countries over the period 1960-2003. We find no evidence that deficits help reelection in any group of countries -developed and less developed, new and old democracies, countries with different government or electoral systems, and countries with different levels of democracy. In developed countries, especially old democracies, election-year deficits actually reduce the probability that a leader is reelected, with similar negative electoral effects of deficits in the earlier years of an incumbent's term in office. Higher growth rates of real GDP percapita raise the probability of reelection only in the less developed countries and in new democracies, but voters are affected by growth over the leader's term in office rather than in the election year itself. Low inflation is rewarded by voters only in the developed countries. The effects we find are not only statistically significant, but also quite substantial quantitatively. We also suggest how the absence of a positive electoral effect of deficits can be consistent with the political deficit cycle found in new democracies.

Adi Brender adib@bankisrael.gov.il
\end{abstract}

Allan Drazen

Department of Economics

University of Maryland

College Park, MD 20742

and NBER

drazen@econ.umd.edu 


\section{Introduction}

Manipulation of economic policy in election years has been widely studied. Following Nordhaus's (1975) influential model of how expansionary policy before an election can help incumbents to get reelected, there has been a search for empirical evidence linking economic policy and economic performance before elections to the votes that an incumbent receives.

Most research on pre-electoral manipulation did not however examine directly whether expansionary policies or good economic outcomes succeed in attracting votes. Instead, the focus has been on the existence of political business cycles (increases in economic activity in election years relative to non-election years) or political budget cycles (election-year increases in deficits or expenditures or cuts in taxes). The evidence for the former in developed countries is not strong. Alt and Chrystal (1983) summarize early empirical studies for the United States as showing a little evidence of a political business cycle, a point reinforced by results summarized in Alesina, Roubini, and Cohen (1997). Faust and Irons (1999) come to a similar conclusion. Similarly, there is no strong evidence of a significant political business cycle in unemployment or economic growth in other developed economies (Paldam [1979], Lewis-Beck [1988], Alesina, Roubini, and Cohen [1997]).

There is also a literature examining the effects of economic growth on the probability of reelection directly, mostly in developed countries. Generally, the effect of growth on reelection was found to be insignificant in most cross-section studies in developed countries (Powell and Whitten (1993), Paldam (1991), Strøm and Lipset (1984) and Lewis-Beck (1988)). The U.S. seems to be an exception to these findings, where Fair (1978) found a significant effect of growth on voting in presidential elections, as did Alesina and Rosenthal (1995). No similar analysis was done for less developed countries.

The lack of convincing evidence for a political business cycle led researchers to focus on political cycles in economic policy. Though Nordhaus considered expansionary monetary policy (inducing a movement along the Phillips curve), current research focuses on the effect of expansionary fiscal policy, especially higher deficits, on an incumbent's reelection prospects. Many empirical studies find evidence of a political budget cycle, with the common view that political budget cycles are a phenomenon more of less-developed countries than of developed ones. ${ }^{1}$

${ }^{1}$ For a summary see Drazen (2001) or Brender and Drazen (2005a). 
Two recent studies find evidence that the political budget cycle is present in both developed and less-developed countries. Shi and Svensson (2002) in a panel data set of 91 countries over 1975-95, both democracies and non-democracies, find that, in an election year, the government surplus falls significantly in both less-developed and developed countries (though the effect is far stronger in less-developed countries). Persson and Tabellini (2003, chapter 8) argue that there is a strong political budget cycle in both developed and less-developed democracies over the period from 1960 to 1998 . They find a political revenue cycle (government revenues as a percent of GDP decrease before elections), but no political cycle in expenditures, transfers, or the overall budget balance.

In contrast, Brender and Drazen (2005a) argue that political budget cycles found in such large cross-section studies are driven by the experience of "new democracies", that is, by the experience of newly democratic countries in up to the first four elections after the transition to democracy. It is the strong fiscal cycle in these countries that accounts for the finding of a fiscal cycle in larger samples including these countries, which disappears once the new democracies are removed from the larger sample. The political budget cycle in new democracies accounts for any significant cycle in both developed and less developed economies; for the finding that the cycle is stronger in weaker democracies; and for differences in the political cycle across government or electoral systems.

In contrast to the fairly extensive direct tests of overall macroeconomic performance on election outcomes, there are few tests of fiscal performance on election outcomes, and none on the national level of which we are aware. ${ }^{2}$ Peltzman (1992), Brender (2003), and Drazen and Eslava (2005a) examine the direct effect of fiscal performance on reelection at the state and local level in a single country (the United States, Israel, and Colombia respectively), and find that voters punish - rather than reward - loose fiscal policies in general, as well as in election years. None of these country studies examines directly whether fiscal expansions during election years at the national level help incumbents to get reelected. Moreover, any empirical conclusions one might draw should, strictly speaking, be limited to these countries, rather than applicable to a broad cross-section of countries analogous to the studies of the political budget cycle itself.

To summarize, existing studies do not provide a direct answer to the question whether

2 Alesina, Perotti and Tavares (1998) analyze the effects of fiscal adjustments in a cross section of OECD countries, but focus on cabinet changes, rather than on election results. 
election year deficits are a useful instrument for gaining reelection in those countries for which a political deficit cycle has been found, nor in the broader cross-section of countries for which political budget cycles have been studied. That is, the key question which forms the basis of large cross-country studies of the political budget cycle has not been tested on a data set covering the same countries!

In the current study we look directly at the effects of fiscal performance and growth on reelection in various groups of countries. Using information on 350 election campaigns in 74 democracies we examine whether: 1) increased deficits during an election year raise the probability of reelection; 2) loose fiscal policies during the term in office help reelection; 3) GDP growth during the term in office, and specifically in the election year, helps incumbents to get reelected; and, 4) these forces work differently in countries at different levels of economic development, strength of democracy, or with different electoral or government systems.

The plan of the paper is as follows. In the next section we summarize some of the conceptual arguments on how fiscal or economic performance may affect voting behavior. In section 3, we describe the dataset and variable definitions. Section 4 sets out the basic empirical results on the effect of deficits and growth on the probability of a leader's reelection. We find no evidence that larger deficits during an election year or over the term increase the probability of reelection, with rising deficits having a clear negative effect in developed and old democracies. Economic growth over the leader's term has a positive effect on the probability of reelection only in less developed countries and new democracies. In section 5 we examine the robustness of these findings to various different specifications. In section 6 we consider differences in the effects of deficits and growth on reelection in old and new democracies, while in section 7 we investigate the importance of different government or electoral systems, or the level of democracy for these effects. The lack of support for the electoral value of deficit spending characterizes all these different country groupings. In section 8 , we consider some alternative explanations of our results, as well as addressing the question of why expansionary fiscal policy doesn't appear to gain votes for the incumbent even in new democracies where our earlier work found a clear political budget cycle. Section 9 contains conclusions.

\section{Performance and Reelection}

In this section we review both the conceptual arguments on why election-year expansions in general or fiscal expansions in particular might help an incumbent's reelection prospects, as 
well as some of the arguments why in fact we may not observe such effects and may even observe punishment for election-year deficits.

\section{A. Economic growth and reelection}

There are a number of basic, intuitive arguments on why growth could help reelection. Most obviously, since economic policies affect economic performance, it would not be surprising that good macroeconomic results would be taken as indicating that a leader has good skills to run the country.

This may reflect simple retrospective voting rules. As Nordhaus (1989, p. 39) puts it:

In light of their rudimentary understanding of the intricacies of legal, political, and economic structures, voters might be generally unable to distinguish policy shocks from external shocks and simply hold the incumbent government responsible for whatever events transpired. In short, ... retrospective evaluation of the performance of incumbents on the bases of simple and easily understood indexes (such as unemployment, GNP growth, or inflation) might be a reasonable way for many voters to make political decisions.

The use of such retrospective voting rules by rational, forward-looking voters could be motivated by assuming that good performance may be a sign of competence, which is valued by voters but cannot be directly observed, as for example, in Persson and Tabellini (1990). (Rogoff [1990] and Rogoff and Sibert [1989] were the first to formalize this for fiscal policy, as discussed below. ${ }^{3}$

On the other hand, voters may perceive that in a global economy governments may matter only a little for certain types of economic performance, including sustained economic growth. Their voting behavior might then be relatively unaffected by some measures of good economic performance, especially in small open economies. (The significant effect of economic growth on election results found for the United States may be due in part to its being a dominant and relatively closed economy.) A growth spurt in the election year itself might be especially suspicious and hence would be less likely to affect voters.

Which of the general views set out in the previous two paragraphs better describes voters in a given country may depend on its characteristics, specifically the newness of the democracy and whether it is a developed or less developed economy. The first distinction follows our results discussed above on the presence of a fiscal cycle in new democracies versus its absence in

\footnotetext{
3 Another argument is simply that high GDP implies higher government revenues and thus improved government services. To the extent that voters tie these improvements to the current incumbent, his reelection chances may be improved.
} 
established democracies. Based on this difference, it would not be surprising if voting patterns responded in fact to economic outcomes more in new than in old democracies. A further piece of evidence suggesting different voter response is based on responses reported in the World Values Survey (Inglehart et al. [2004]). In new democracies used in our study that were covered by the World Values Survey, respondents care more about good economic performance than in old democracies. A statistically significant larger fraction of respondents in new democracies responded that a high level of economic growth or (separately) a stable economy is the most important target for their country among several policy targets. This effect is significant even when one controls for the level of income and the demographic structure of the country. The same analysis also showed a statistically significant negative correlation between the proportion of respondents who thought that these two targets were the most important and the level of GDP per-capita in a country. ${ }^{4}$ Hence, the empirical question arises as to whether the effect of economic growth on voter behavior is in fact different in new versus old democracies and in developed versus less developed countries, questions that we address here.

The possible difference in voter response to economic growth in developed versus less developed countries is suggested by the difference in the existence of a political business cycle in the two types of economies - that is, the clear absence of a cycle in developed economies versus the seeming less clear rejection in less developed economies. Here too, there is no empirical study of a large cross-section of developed and less developed countries that addresses whether there is a difference in the effect of economic growth on an incumbent's reelection chances. We address this question as well.

\section{B. Deficits and reelection:}

Analogous to our discussion in the previous subsection, we begin by reviewing the arguments on why an incumbent's reelection chances may be helped (or harmed) by expansionary fiscal policy in general, and in election years in particular. We begin with the arguments of why fiscal expansions and deficit spending may help incumbents gain votes so that politicians may be expected to engage in it and that empirically it is widespread. Such a view underlies much of the literature on the political budget cycle.

The simplest argument follows from the argument above that good economic performance

4 For more details see Brender and Drazen (2005b). 
helps an incumbent's reelection chances. To the extent that expansionary fiscal policy can be successfully used to manipulate macroeconomic outcomes and provide higher growth, which in turn, it is argued, gains votes for the incumbent, loose fiscal policy will help an incumbent's reelection prospects. As already noted, there is also theoretical work, such as Rogoff (1990), arguing how fiscal expansions during election years could lead rational voters to vote for incumbents who produce them because it signals high competence when there is uncertainty about the incumbent's ability.

Another argument concerns the effectiveness of "pork barrel" spending - that is, spending targeted to specific groups - in gaining votes for the incumbent. There is a large literature investigating the use of such spending projects to gain votes, (as well as a large folk wisdom about its extensive use), though much of it not in the context of political budget cycles per se.

A third, general sort of argument on the effectiveness of fiscal policy in gaining votes is that voters simply prefer low taxes and high spending and reward politicians who deliver these. Of course, there is the question of why such voters would "ignore" the government's intertemporal budget constraint in rewarding deficit-producing politicians. One set of responses focus on various sorts of fiscal illusion. The Rogoff argument mentioned above relies on imperfectly informed, rational voters, who observe higher expenditures (or lower taxes) but believe that more competent policymakers can provide these without necessarily incurring higher deficits. ${ }^{5}$ More generally, the type of Nordhaus (1989) argument set out above on voter response to good economic performance might justify similar response to low taxes or high expenditure.

As with the effect of good economic performance, there are a number of reasons to believe that loose fiscal policy need not help an incumbent's reelection chances and may actually harm them. Rational voters may well be "fiscal conservatives" who punish rather than reward deficit spending and fiscal manipulation, even more so if it is perceived as electorally motivated. The competence models of Rogoff and others rely on imperfect information about fiscal policy; were information perfect, rational voters would not be swayed by electoral manipulation. Peltzman (1992), for example, shows that voters in the U.S. are less likely to support a state or local official who has increased overall spending before the election.

\footnotetext{
${ }^{5}$ A key innovation of Shi and Svensson (2002) is that the policymaker chooses fiscal policy before he knows his competence level, so that all "types" choose the same level of expansion. An implication is an aggregate deficit cycle.
} 
Furthermore, even if good economic conditions help an incumbent's chances of reelection, it is not clear that fiscal manipulation will be effective. Though a "strong economy" may help incumbents' re-election prospects, politicians may have very limited ability to successfully manipulate the economy to help their re-election chances. In addition to a policymaker's lack of technical ability to time the expansion accurately enough to happen just before the elections, it is argued that manipulating economic activity is considered harmful in terms of "unsmoothing" consumption, inducing investment cycles, etc. Here too, rational, wellinformed voters should not support such policies, so that pre-electoral manipulation would be punished rather than rewarded at the polls. Similarly, targeted spending may lose votes if it is perceived as electoral manipulation. ${ }^{6}$

To summarize, as in the case of the effects of economic growth on an incumbent's reelection, there are conceptual arguments on both sides. We believe that there are good arguments why fiscal manipulation will not work in most countries, while the arguments why it might work are reasonable only in some groups of countries. As with economic conditions and voting patterns, there is no empirical work testing the connection between aggregate fiscal policies and an incumbent's budget deficits for a large cross-section of countries. The absence of political budget cycles in fiscal aggregates in all countries other than new democracies gives reason to doubt whether deficit spending has significant effects on voting patterns in established democracies, even though this is the implicit assumption of papers that find such a cycle. Hence, there is a need to confront the different views with the data.

\section{Data and Variable Definitions}

The dataset used in this study is based on information from several sources (see Table A1). Fiscal data are taken mostly from the IFS, national accounts data from the World Bank's World Development Indicators and the IFS, information on the political structure of countries, their electoral system and additional political variables is constructed using the World Bank's database of Political Institutions (DPI) and data on the level of democracy are taken from the Polity IV dataset at the University of Maryland. A detailed description of the data sources and the construction of the variables appears in Appendix I. The combination of sources allows us to use

6 Drazen and Eslava (2005b), however, present a model of political cycles in pork barrel spending in which an expenditure cycle may exists even if a targeted group of voters know it is being targeted. 
data for 74 countries over the period 1960-2003. Overall we have useable information on 347 election campaigns that took place in periods where these countries were democratic. The countries and election campaigns are listed in Tables A-2 and A-3, respectively.

The key political variable REELECT is a binary variable with a value of 1 if the incumbent was reelected and 0 if he or she was not. Its construction was based on information from the "World Political Leaders 1945-2005" database of Zárate's Political Collections (ZPC) and from the "World Statesmen" encyclopedia. These data allowed us to follow the terms of individual leaders in office from appointment to termination, and to associate them with election dates. The decision whether the prime minister or the president is the leader is based on the DPI dataset classification, as described in Persson and Tabellini (2003). Information on election dates and results (presidential elections in presidential systems and parliamentary elections in parliamentary ones) is taken from the International Institute for Democracy and Electoral Assistance (IDEA) dataset "Voter Turnout Since 1945", from the International Foundation for Election Systems ELECTION GUIDE dataset and is supplemented by Binghamton University's Election Results archive.

We use two definitions of REELECT throughout the analysis. In the narrow definition we include only observations where the leader is running for reelection herself (either as the leader of her party in parliamentary elections or personally in presidential ones). We constrain the sample to observations of leaders who were in office for at least two fiscal years prior to the elections and were candidates in the elections or retired within the month before the elections (in which case we classify the leader as losing reelection). In the expanded definition we add cases in which a leader was substituted by another candidate from his party under the following specific circumstances: 1) the leader died in the year before the elections; 2) the leader could not run for reelection due to legal term limits. In these cases the substitute leader (in the first case) or the candidate from the leader's party (in the second case) is treated as the incumbent. Additionally, in the expanded sample, we treat leaders who quit their job within a year before the elections as having lost reelection (that is, the binary variable REELECT has a value of 0), while in the narrow sample it is defined as a missing value as long as the leader quits more than a month before the elections. This latter classification is in line with the methodology of Alesina, Perotti, and Tavares (1998) and Brender (2003).

In Table 1 we show the distribution of election campaigns according to the two definitions. There are 255 campaigns in the narrow sample which are evenly split between 
successful and unsuccessful reelection attempts. About two thirds of the observations are in developed countries (23 OECD countries, see Table A-2) and the probability of reelection among them is somewhat higher than in the undeveloped countries. A breakdown of the sample between established and new democracies reveals that three quarters of the sample come from established democracies. The use of the expanded definition adds 92 observations to the data, mostly undeveloped countries. It also increases substantially the number of elections in new democracies. However, the change in definitions also increases substantially the proportion of campaigns where the incumbent (or his substitute) are not reelected. This is a reflection of both the lower success rates of substitute candidates, and the inclusion of those observations where the candidate has quit his job within the year before the elections.

The use of the narrow sample has the advantage of focusing only on the cases where the same person who led the government before the elections is the one seeking reelection. The homogeneity of this sample may reflect a clearer relationship between performance and reelection and avoids questions of the extent to which voters associate the new candidate with the policies of his predecessor. On the other hand, using the narrow definition means a substantial loss of information. We therefore present in the remainder of this paper results using both samples.

We examine fiscal performance using two variables BALCH_term and BALCH_ey. The first variable reflects the change in the central government's balance (that is, budget surplus) to GDP ratio over the term in office by comparing the average balance/GDP ratio in the two years before the election year with that in the previous two years. The second variable is the change in the balance/GDP ratio in the election year relative to the previous year, which is an indicator for election year fiscal expansions. Both variables are calculated on the basis of IFS data, supplemented with GFS data, as described in Brender and Drazen (2005a). All our data are adjusted to fiscal years. (In 12 of the countries the fiscal year does not overlap the calendar year.) While in some cases it is not clear which fiscal year should correspond to the election year, especially when the elections take place in the early part of the year, Brender and Drazen (2005a) and others (for example, Alesina, Perotti and Tavares [1998]) find that the relationship between fiscal policy and the timing of elections is not very sensitive to the definition used. Nevertheless, we also present below some sensitivity indicators to show that our results are not qualitatively affected by the definition. 
Our indicator for macroeconomic performance is GDPPC_gr, which is the average annual growth rate of real GDP per capita between the current and the previous election year. In cases where the leader assumed power after the previous elections, we calculate GDPPC_gr only over the period since his appointment. We also include, separately, in some of our equations, the real growth rate of GDP in the election year. Finally, we calculated the deviation of GDP from its long term trend (using a country-specific Hodrick-Prescott filter) for each country in each year, and used this variable in some of our equations as a control for the business cycle.

\section{The Effect of Deficits and Growth on Reelection}

We begin with the basic results. In Table 2 we examine the effect of deficits and growth on the probability of reelection using Probit estimation. ${ }^{7}$ In columns 1 and 4 we show the unconditional effects in the narrow and expanded samples, respectively. The equations show that voters are likely to punish persistent budget deficits over the term in office (a negative value of BALCH_term implies a loss of votes) rather than reward leaders who create them. The coefficient of the change in the deficit to GDP ratio over the term in office, excluding the election year, is positive and statistically significant, indicating that the probability of reelection is increasing when the fiscal balance improves during the leader's term in office. Moreover, we find no indication that larger deficits during an election year (a negative value of BALCH_ey) increase the probability of reelection. In fact, in the narrow sample we find a statistically significant positive effect of improved fiscal balances during the election year on reelection. That is, leaders that reduce the deficit during an election year, relative to the previous year, have a higher probability to be reelected. The coefficient in the expanded sample is also positive but not statistically significant $(\mathrm{p}=0.12)$.

Economic growth over the leader's term also has a positive effect on the probability of reelection, in both samples. It appears that voters attribute better macroeconomic performance, at least to some extent, to the functioning of their government, or that stronger macroeconomic performance allows governments to expand their services or cut taxes in a sustainable way, and by that gain electoral support. These findings contrast with those of Powell and Whitten (1993), Paldam (1991), Strom and Lipset (1984) and Lewis-Beck (1988) mentioned in the introduction, who found no significant effect. We argue below that this difference in results is explained by

Logit equations yielded very similar results. 
distinguishing developed from less developed countries.

In addition to the fiscal and macroeconomic variables, we find that the probability of reelection is higher in the developed countries ${ }^{8}$ and in countries with a majoritarian electoral system. In the narrow sample we also find that the probability of reelection is higher in new democracies, as compared to established democracies, but this latter relationship loses its significance in the expanded sample where the number of campaigns in new democracies is much larger on the one hand, but it includes many campaigns where the leader is not seeking reelection personally.

The differences in the probability of reelection between the various groups of countries, along with the findings in the Political Budget Cycle literature that PBCs differ across categories of countries, suggest that the effect of deficits and growth on reelection may also vary across these country categories, so that in some categories of countries election year deficits, or expansionary fiscal policy in general, may be rewarded at the polls, even if they are not in the entire sample. The large share of developed and established democracies in the sample (Table 1) emphasizes the need for such an examination.

In Columns 2 and 5 of Table 2 we therefore look separately at the developed countries that constitute about two thirds of the narrow sample and one half of the expanded sample. In column 2 we find that rising deficits over the term are associated with a lower probability of reelection. In column 5 we find that this effect is still in the same direction in the expanded sample, but that it loses its statistical significance $(p=0.108)$. These results suggest that there is no indication that expansionary fiscal policy helps a leader to get reelected and in fact is likely to reduce his chances of reelection. The loss of significance of this coefficient in the expanded sample may reflect the fact that in the campaigns that are added to the narrow sample, the deficits over the term were generated by the predecessors of politician running as the "incumbent" and were therefore rendered as less relevant by the voters.

The effect on reelection of the change in the fiscal balance in the election year itself is positive and statistically significant in both samples. These results show that not only that expanding the deficit in an election year is unlikely to increase the probability of reelection, in developed countries it is likely to lower this probability.

\footnotetext{
8 Using the level of GDP per capita, instead of a binary variable for developed and undeveloped countries yielded insignificant results and did not affect qualitatively the coefficients of the other variables.
} 
The effect of macroeconomic performance on reelection, as reflected in the real growth rate of GDP over the term, is not significant in the developed countries, neither in the narrow nor in the expanded samples. This finding is consistent with the studies mentioned above, which focused on developed countries. It appears that, as found in those studies, voters in developed economies do not attribute the economic success of their country to the performance of their government, or at least their voting behavior is not significantly affected.

The findings with respect to the less developed countries (columns 3 and 6) are different in some aspects from those for the developed countries. Nevertheless, loose fiscal policies over the term are not rewarded in the less developed countries either. The coefficient of the change in the budget balance to GDP ratio over the term is positive, and in the expanded sample it is also statistically significant. The size of the coefficient is identical in both samples but the additional power in the expanded sample (the number of less developed countries' observations almost doubles in the expanded sample) overtakes the potential moderating effect of including candidates that were not personally in office for the full term before the elections.

The findings are notably different than those in developed countries for the change in the ratio of the fiscal balance to GDP in the election year. The coefficients on this variable are close to zero and are far from being statistically significant. On the one hand, these findings suggest that voters in less developed countries may be more tolerant towards expanding budget deficits in election years, but on the other hand they show that even in these countries, voters do not reward election year deficits.

Finally, economic growth over the term in office is strongly rewarded by voters in the less developed countries. Higher growth has a positive and statistically significant effect on the probability of reelection in both samples. These findings suggest that in the less developed countries voters attribute more of the economic success of their country to their leaders. It is beyond the scope of this paper to explore why this is the case ${ }^{9}$, but we note that it is consistent with the findings of the World Values Survey.

Thus, we find out that the relationship between fiscal and macroeconomic performance and the probability of reelection, found in the broad sample of countries reflect two distinct influences in developed and less developed countries. While loose fiscal policies have a negative

\footnotetext{
${ }^{9}$ We can speculate that it may reflect the more important role of leaders in less developed countries in determining the direction of their country or in securing order and stability which are pre-conditions for growth, while these are taken for granted in developed countries.
} 
effect on the probability of reelection in both sets of countries, deficit expansions in the election year are punished only in the developed countries, while in the undeveloped ones they have no significant effect. On the other hand, macroeconomic expansion has a positive significant effect on reelection in undeveloped countries and no effect in developed ones.

\section{Robustness}

In Table 3 we examine the robustness of these findings to various different specifications. Beginning with this table we allow for different effects of the economic variables by multiplying each one of them by a binary variable that receives a value of 1 for the respective group of countries and a different binary variable for the remaining countries. ${ }^{10}$ In columns 1 and 5 we verify our results by estimating the equations for the full sample (narrow and expanded one, respectively) but allowing different effects of the variables in developed and less developed countries; the results match those of Table 2. In column 2 we examine the effect of including separately the growth rate of GDP during the election year for two purposes. First, we want to test whether including the growth rate in the election year would affect the coefficient of the change in the deficit in the election year. Second, we want to find out if growth in the election year has a stronger impact on voters than growth in the other years of the leader's term. We find that neither of these effects is supported by the data. ${ }^{11}$ In column 3 we check the first effect in an alternative method by controlling for the deviation of real GDP in the election year from its country specific long time trend, which is calculated using the Hodrick-Prescott filter. Again, none of the other coefficients is affected qualitatively by this addition, nor does the variable's own coefficient has a significant positive sign.

In columns 4 and 6 we test whether the effect of deficits in election years is distinct of that of deficits in earlier years. For that purpose we substitute our variable of the deficit over the term, which excluded the election year, with a variable that includes the deficit in the election year. We then check whether the change in the deficit in the election year has an additional effect. We find

\footnotetext{
${ }^{10}$ For example, the entry BALCH term*developed in a table refers to the change in the fiscal balance during the term in office in developed countries and the entry BALCH_term*less_developed refers to the same variable in less developed countries.

11 It should be noted that the overall effect of growth in the election year in undeveloped countries remains positive even if the negative effect of the coefficient of growth in the election year is taken into account because its overall effect also includes the influence of growth over the term, which includes the election year.
} 
that such an effect exists and that it is positive. That is, not only that improving the fiscal balance in general helps reelection, doing so in an election year is even more effective, but only in the developed countries. Moreover, we find no evidence for a positive effect of increased election year deficits in the undeveloped countries.

In Table 4 we examine whether various country characteristics that were identified by Persson and Tabellini (2003) and Brender and Drazen (2005a) as affecting PBCs also influence the effects of fiscal performance and growth on reelection. In columns 1 and 4 we find that controlling for the type of political system - parliamentary vs. presidential - has no qualitative effect on the coefficients of the election year deficit and growth. In equations 2 and 5 we introduce a control for whether the elections took place in their predetermined date or sooner. We find that having the elections in their predetermined data does not change the probability of reelection, nor does it affect the impact of the other variables on reelection. Finally, in columns 3 and 6 we test whether the level of democracy (as characterized in Appendix I) has an effect on reelection or the signs of the other coefficients, and find no significant effect. Thus, the positive effects of improved fiscal balances in the election year and during the term in developed economies, and that of higher GDP growth in the undeveloped countries do not seem to reflect these other country characteristics.

The effects of fiscal policy and macroeconomic performance that we find are not only statistically significant, but also quite substantial quantitatively. In Table 5 we report the effect of each of our three key variables on the probability of reelection. ${ }^{12}$ We find that an increase of 1 percentage point in the central government surplus ratio to GDP can increase the probability of reelection by 3-4.5 percentage points in the developed/established democracies and that an increase of 1 percentage point in the surplus during an election year increases the probability of reelection by 7-9 percentage points. These magnitudes are broadly in line with those reported in Brender (2003) for similar variables in the local elections in Israel. In the less developed countries/new democracies raising the average growth rate during the term by 1 percentage point is associated with a 7-9 percentage points increase in the probability of reelection.

\footnotetext{
12 The probit coefficients cannot be used directly as elasticities or semi-elasticities. The effect of the variables is calculated at the averages point for the developed and less developed countries separately.
} 


\section{Old and New Democracies}

Brender and Drazen (2005a) show that the existence of a statistically significant political cycle in fiscal aggregates critically depends on the "newness" of its democratic regime; political budget cycles are much more common in the first four elections after the country becomes a democracy, than in later elections. In Table 6 we test whether the prevalence of PBCs in new democracies is associated with a positive payoff to deficit spending at the polls. We estimate the previously specified probit equations on the full samples allowing for different effect of the fullterm and election year budget balance, and of growth in new and old democracies.

In the old democracies we find that both the full term and the election year increase in the ratio of the fiscal surplus to GDP increase the probability of reelection, while the effect of GDP growth on reelection is only significant when the expanded sample is used. In equations 3 and 6 we find that the positive effect of an improvement in the fiscal balance is similar in election and non-election years in the old democracies, and equations 2 and 5 show that the relationship between changes in the fiscal balances and reelection is not affected qualitatively by controlling for growth in the election year.

In the new democracies - the group of countries for which we found a significant political budget cycle in our earlier paper - we find no significant effect of the fiscal balance on the probability of reelection. This is an unexpected finding given the results in Brender and Drazen (2005a), if one believes that the rationale for the existence of political budget cycle is that opportunistic leaders run deficits because it helps (or is believed to help) their reelection prospects. The joint findings that PBCs exist in new democracies and that fiscal expansions in election years do not raise the probability of reelection suggest that one must find an alternative explanation for the observed fiscal expansions in election years in new democracies. We discuss this in more detail in section 8.

We find a significant effect of GDP growth over the term on the probability of reelection in new democracies, which is consistent with the importance put on economic growth by respondents to the World Values Survey in new democracies. In equations 2 and 5 we find that this effect is not stronger if growth takes place during the election year, as compared to earlier years in the incumbent's term. This finding contradicts much of the logic behind the PBC literature that argues that fiscal expansions during election years are used to accelerate growth just before the elections. To summarize, not only are election-year fiscal expansions not rewarded 
by voters, even in the group of countries where they are most common, but even growth in the election year itself does not affect voters when growth over the entire term is controlled for.

In Table 7 we allow for a more detailed breakdown of the effects of deficits and growth by allowing for different effects in developed and less developed old democracies ${ }^{13}$. Deficits are punished in old democracies that are developed, while in old democracies which are less developed, they are not punished. However, as with all other classifications, we find no indication that deficits - either over the term or in the election year - increase the probability of reelection. We also find that the positive effect of growth on reelection in the established democracies is entirely due to the less developed ones. Equations 2 and 4 show that these effects are robust to the inclusion of a countries' position in the business cycle, as reflected in the deviation of GDP from its trend. ${ }^{14}$

\section{Political Characteristics and Electoral Systems}

Persson and Tabellini (2003) among others argue that the structure of the political system and the electoral system have a substantial effect on the possibility and desire of leaders to engage in political manipulation, which would be reflected in PBCs. There are also differences between countries in the level (or strength) of their democratic system which may affect the degree to which leaders may find it useful to engage in fiscal manipulation and that voters would reward it. We therefore test below whether the effects of fiscal balances and growth on reelection differ across these categories of countries, and whether there may be a group of countries where fiscal expansions during election years are rewarded. In Table 8 we provide the breakdown of the samples into the various country categories, and separately for the developed and undeveloped countries and for the old and new democracies. We find out that there are very few developed countries that use a presidential system and very few elections that took place in developed countries at times that democracy was not at the highest level as measured by POLITY IV. We also find that there are relatively few new democracies with the highest level of democracy or with a majoritarian electoral system.

In Table 9 we examine whether the effects of deficits and growth on the probability of

13 There are only 11 elections in developed new democracies so we do not present the results with a breakdown of the new democracies to developed and undeveloped countries. Estimating the equations with this additional breakdown did not change any of the results qualitatively.

14 The results are similar when we control for the growth rate of real GDP instead of the deviation from the trend. 
reelection differ across political and electoral system ${ }^{15}$. We find that the positive effect of improved budget balances during election years remains significant in parliamentary systems in developed countries (column 1). The coefficient for the elections conducted in developed countries employing the presidential system is of the same magnitude but is not statistically significant, perhaps due to the small sample. We also find the same effects in proportional election systems while the positive effect in majoritarian elections is not statistically significant (column 2). There is no statistically significant effect of the election year fiscal balance in any direction in the less developed countries, regardless of the political and electoral system. Improved fiscal balances over the term help reelection in parliamentary and majoritarian elections in the less developed countries. Finally, growth has a significant positive effect on reelection in the less developed countries, regardless of the political and electoral system. Overall, these findings suggest that while the political and electoral systems may influence the relationship between fiscal performance and reelection, in no case is there evidence that loose fiscal policies, or fiscal expansions during an election year, help an incumbent to win.

In columns 1 and 3 of Table 10 we examine whether the level of democracy (as measured by POLITY IV) influences the impact of fiscal performance and growth on reelection. We find the same positive relationship between the change in the government budget balance in the election year and reelection, although the small number of elections in developed countries with a low level of democracy keeps the effect in that group not statistically significant. Among the less developed countries we find some indications for a positive effect of reduced deficits over the term on reelection in countries with a low level of democracy, and no statistically significant effect of the election year deficit. Finally, growth has a positive effect on reelection in the less developed countries, regardless of their level of democracy.

In columns 2 and 4 of the table we check whether there is a difference in these relationships between elections that take place on their predetermined date and elections that take place "early". 16 Early elections may reflect an attempt of the incumbent to hold an election when he is popular (and presumably the economy is strong), but it may also result from a weakened leader being pushed to elections when the economic situation is bad. Hence the timing may be

15 We present only the results for the narrow sample, but the results in the expanded sample (available upon request) are qualitatively the same.

16 If the election was held in the expected year we classified it as "predetermined"; otherwise it was classified as "early". 
endogenous to the growth rate (or some other economic variable), though the sign of the relation is not clear ex ante. This endogeneity may in turn affect the relationship between economic conditions and the probability that the incumbent is reelected. We find that the directions of the relationships are the same regardless of whether the elections are on the their original, predetermined date or are held early, although the positive effect of improved fiscal balances during the election year on reelection is significantly larger when elections are early. ${ }^{17}$

In Table 11 we examine the effects of the political and electoral system on the effects of changes in the fiscal balance and growth on reelection in old versus new democracies. We find a positive effect of improvements in the fiscal balance on reelection in old democracies with parliamentary systems (column 1) and with proportional electoral systems (column 2). The positive coefficient in presidential systems is even larger than in parliamentary ones, but the small sample may account for its lack of significance. We find no effect of deficits on reelection in new democracies, regardless of the political or electoral system, while the effect of growth in these countries is significant in both political systems and both electoral systems, while it is not significant in any category of old democracies.

In Table 12 we find the same results with respect to the division of the old and new democracies into those with a high level of democracy and those with a low level (columns 1 and 3). We find again that rising deficits hurt the probability of reelection in old democracies with a high level of democracy and do not help it in those with a low level of democracy or in new democracies. We also find a positive effect of growth on reelection in the old democracies, at both levels of democracy.

In columns 2 and 4 of the table we show the results with respect to the division of elections in old and new democracies into those that were held on the scheduled ("predetermined") date and those that were held early. We find that when there are early elections, an improved fiscal balance in new democracies helps reelection, while when the elections were held on the originally scheduled date the effect is not statistically significant. ${ }^{18}$

Since we use annual data in our sample, the effects of budget deficits on reelection could

17 The coefficient on election year fiscal balance is 36.8 for early elections versus 16.5 for elections held on the scheduled date in the narrow sample and 33.2 for early versus 13.9 for elections on the scheduled date in the expanded sample. Note, However, as shown in Section 5, early elections are not associated with a higher probability of reelection (Table 5).

18 One possibility is that the leaders who succeed in lowering the deficit may be the ones who call early elections, while those who do not are more likely to postpone elections as long as possible. 
be "clouded" by campaigns that take place in the early parts of the year, if the government expanded the deficit in the previous year or took corrective measure in the later part of the year, after the elections. While Brender and Drazen (2005a) find no evidence that larger fiscal expansions take place in election years in which the elections are in the later part of the year, we allowed for varying effects of the deficit if the elections are in the first half of the year, or in the second half. We find that there is no statistically significant positive effect of the deficit in the election year on reelection, even among the new democracies, either when the elections are in the first half of the year or in the second half.

In Table 13 we show that the positive effects of improved fiscal balances on reelection in old democracies reflect the behavior of the old developed democracies, while the effects in the less developed old democracies are not statistically significant. We also find that the positive effect of growth in established democracies is entirely due to the experience of the less developed established democracies, while in the established developed democracies the effect is far from being significant. These results are repeated in Table 14 with respect to the different levels of democracy and the type of elections: predetermined or early. Again, there is no group of countries in which there is a statistically significant positive effect of budget deficits - either in the election year or over the term - on the probability of reelection.

\section{Alternative Explanations}

To characterize our main finding in a sentence: voters, especially in developed countries and established democracies, do not like deficits, particularly in election-years. The negative electoral effect of deficits in some groups of countries and the lack of a significant positive effect in any group of countries seems quite clear. Are there alternative interpretations of our findings?

One of the questions that may arise with respect to these findings is that of causality. It may be argued that strong leaders have the political power to conduct conservative fiscal policies (see, for example, Roubini and Sachs (1989)) and at the same time have a better chance to be reelected. In order to control, at least to some extent, for this possibility we collected data on the share of the votes received by each leader in the previous election and his party's strength in the legislature, taking into account various aspects of the nature of the electoral system. When the leader is elected directly, the vote share he received in the previous election gives some indication 
of his popularity and thus his political strength. ${ }^{19}$ In a parliamentary system, the percent of seats in the parliament held by the leader's party may, in a similar way, represent his popularity and indicate his ability to carry out his program. In Table 15 we show that none of the relationships we identified above is affected by the inclusion of these variables, although the additional variables have the expected, statistically significant, effect on the probability of reelection ${ }^{20}$. These findings suggest that the effect of improved fiscal positions on reelection is not merely a reflection of the use of the leader's political power to better control fiscal developments.

Another explanation of our findings is that voters are not bothered so much by deficits per se, but by inflation which itself is often caused by deficit spending. Shiller (1996), Lewis-Beck (1988) and Alesina, Perotti, and Tavares (1998), among others, find evidence that voters dislike inflation and punish governments that create it. To control for this possibility we added in Table 16 the inflation rate in the election year, the change in the inflation rate during the election year and the average inflation rate during the leader's term in office. We find that all these variables have a statistically significant negative effect on the probability of reelection in the developed countries, and no effect in the less-developed ones. However, the inclusion of these variables does not affect the relationship between the fiscal and growth variables and the probability of reelection. That is, our finding of dislike of deficits reflects more than dislike of inflation.

An alternative explanation for our finding that growth has no effect on the probability of reelection in developed countries may be that it is due to the significant impact of global economic developments on the growth performance of these countries. If this is the case, it may still be that voters reward policy induced growth, but this component would not be observable in the data due to the dominant effect of global factors.

To test this possibility we try to separate the effects of global economic developments by running a regression of the real growth rate of per-capita GDP during the leader's term on the product of the real growth rate of world GDP and the share of exports of goods and services in the country's GDP (both variables taken from the WDI). We estimated these regressions

19 In some of the countries that have a presidential system it is not trivial to match the president with a specific party, or even with a group of parties. We also tested the effects of the size of the coalition in the year before the elections and (jointly) the proportion of seats held by the leader's party within the coalition representation. This variable did not have a significant effect on the probability of reelection and did not affect any of the other coefficients.

${ }^{20}$ We show in columns 1 and 5 that the results are not affected by the decrease in the number of available observations due to the inclusion of this variable. 
separately for developed and less developed countries. We then entered, separately, the predicted values from these regressions and the residual growth rates into our original regressions, instead of our original growth variable. In this way, the first variable GLOBAL_gr captures the effect of global developments while the second, DOMESTIC_gr captures mostly domestically induced growth. We use the same coefficient for all the countries in the group because a stronger or weaker response in a country to global developments may itself be a policy outcome .

The results of this estimation are reported in Table 17. We find that in the developed countries neither the effect of global growth nor the effect of domestically induced growth is statistically significant. This finding may suggest that in these countries even the domestic component of growth is attributed to the success of the business sector, rather than to the performance of the government. In the less developed countries we find that the global (exogenous) component of growth does not have a statistically significant effect on the probability of reelection, while the domestic component is the one that accounts for the highly significant effect of growth that we find. This is consistent with a rational behavior of voters that reward their leaders only for growth that is related to domestic factors, which may be more reflective of their own performance. Finally, in both developed and less developed countries the division of growth into the domestic and global components did not affect qualitatively any of the other coefficients.

Our findings for new democracies raise another question when compared with those of Brender and Drazen (2005a) on the existence of political budget cycles. There we found that political cycles in fiscal aggregates exist only in new democracies and that in these countries the effect is entirely due to higher expenditures in the election year. ${ }^{21}$ In this paper we find that even in elections that take place in new democracies there are no indications that fiscal expansions in the election year increase an incumbent's probability of reelection, either directly or via higher election year growth (see Table 4). Why then would rational politicians in new democracies engage in systematic fiscal expansions in election years, as found in our earlier paper?

21 In Table 17 we also test whether voters are sensitive to the source of fiscal expansion. We find that there is no statistically significant difference in the effect of deficits that are created by higher expenditures and those that created by lower revenue, although in the developed countries the effect of revenue reductions (as a share of GDP) is somewhat larger. 
One possible explanation of these joint findings is that the fiscal expansions in election years in new democracies do not represent an attempt to gain voter support for the leader but reflect expenditures incurred in an attempt to consolidate democracy. As described in Brender and Drazen (2005b, in progress), democracy is often not "consolidated" in new democracies, that is, it is not accepted unconditionally by all citizens. We argue that an election year may be an especially dangerous time for the existence of the democracy itself, and thus may be a time when leaders have to spend money to retain popular support for the democratic regime to prevent its overthrow or subversion and the return to an autocratic system. We would then observe higher expenditures and deficits in an election year, but without fiscal expansion necessarily gaining votes for the incumbent over the challenger. Testing this hypothesis empirically is beyond the scope of this paper, but further conceptual discussion can be found in the above mentioned paper.

\section{Conclusions}

In this paper we step backwards in the chain of reasoning underlying the opportunistic political budget cycle to test whether an increase in the government's budget deficit during an election year actually helps the incumbent get reelected. We find no evidence that this is the case in any of the groupings of countries we examine. This includes: developed countries, less developed countries; new and old democracies; countries with presidential or parliamentary government systems; countries with proportional or majoritarian electoral systems; and, countries with different levels of democracy. We also find that it makes no difference for the results whether the elections take place at their originally scheduled date or are called early.

In fact, we find that in developed countries and established democracies election-year deficit spending and tax cuts are punished at the polls. A worsening of the government's fiscal balance in the election year actually reduces the probability that the leader is reelected.

We find similar results for the effect of budget deficits in the earlier years of an incumbent's term in office. In most countries loose fiscal policies over the incumbent's term of office - reflected in larger budget deficits relative to earlier periods - are also associated with a statistically significant lower probability of reelection. Even when one cannot find a significantly lower probability, there is no evidence that deficits raise the probability of reelection. That is, in groupings of countries, deficits either lower the probability of reelection or have no statistically significant effect either way. The findings with respect to election year budget deficits may simply mirror negative voter reaction to budget deficits in other years as well. To the extent that 
voters dislike deficits in general (that is, they are "fiscal conservatives"), it is probably especially difficult to persuade them that they are "good" in an election year. Such fiscal conservatism would lead rational voters to view election-year deficits as clear and costly electoral manipulation and react quite negatively.

We also find that strong macroeconomic performance, reflected in higher growth rates of real GDP per-capita, is associated with a higher probability of reelection only in the less developed countries and in the new democracies. Consistent with previous studies (other than in the US) we do not find significant effects of growth on reelection in developed countries. We also found that in the less-developed countries voters are affected by the overall growth performance over the leader's term in office, but with no additional effect for growth in the election year itself. This finding is not consistent with the proposition in the political business cycle literature that leaders could gain voter support by manipulating the economy to grow faster in election years.

Moreover, the effects we find are not only statistically significant, but also quite substantial quantitatively. An increase of 1 percentage point in the central government surplus ratio to GDP can increase the probability of reelection by 3-4.5 percentage points in the developed/established democracies and an increase of 1 percentage point in the surplus during an election year increases the probability of reelection by 7-9 percentage points.

Our results should raise further questions about the existence of political cycles in fiscal aggregates and especially in deficits as a widespread occurrence. We are not arguing that election-year political manipulation does not exist as a general phenomenon. It may take the form of changing the composition but not the level of expenditures (as in Drazen and Eslava [2005a]) or in targeting some voters at the expense of others so as not to increase the overall deficit (as in Drazen and Eslava [2005b]). But, our results say clearly that running deficits in an election year is not an effective tool to help reelection and in fact is punished at the polls in developed countries that are established democracies. Politicians, take note! 


\section{References}

Alesina, A., A. Perotti and J. Tavares (1998), "The Political Economy of Fiscal Adjustments", Brookings Papers on Economic Activity 1:1998, 197-248.

Alesina A. and H. Rosenthal (1995), Partisan Politics, Divided Government and the Economy, Cambridge, UK: Cambridge University Press.

Alesina, A., N. Roubini and G. Cohen (1997), Political Cycles and the Macroeconomy, Cambridge, MA: MIT Press.

Alt, J. and A. Chrystal (1983), Political Economy, Berkeley, CA: Berkeley University Press.

Brender, A. (2003), "The Effect of Fiscal Performance on Local Government Election Results in Israel: 1989-1998," Journal of Public Economics 87, 2187-2205.

Brender, A. and A. Drazen (2005a), "Political Budget Cycles in New Versus Established Democracies," Journal of Monetary Economics 52, 000-000.

(2005b), "Electoral Economics in New Democracies: Affecting Attitudes About Democracy," in progress.

Drazen, A. (2001), Political Business Cycle after 25 Years, in B. Bernanke and K. Rogoff, eds. NBER Macroeconomics Annual 2000, Cambridge, MA: MIT Press, 75-117.

Drazen, A. and M. Eslava (2005a), "Electoral Manipulation via Voter-Friendly Spending: Theory and Evidence," working paper. (Earlier version circulated as NBER Working Paper 11085).

(2005b), "Pork Barrel Cycles,” working paper.

Fair, R. (1978), “The Effect of Economic Events on Votes for President," Review of Economics and Statistics 60, 159-72.

Faust, J. and J. Irons (1999), "Money, Politics, and the Post-War Business Cycle," Journal of Monetary Economics 43, 61-89.

Inglehart, R., et al. (2004), "World Values Surveys and European Values Surveys, 1999-2001," Ann Arbor, MI: Inter-university Consortium for Political and Social Research.

Lewis-Beck, M. (1988), Economics and Elections: The Major Western Democracies, Ann Arbor: University of Michigan Press.

Nordhaus, W. (1975), “The Political Business Cycle,” Review of Economic Studies 42, 169-90. 
(1989), “Alternative Approaches to the Political Business Cycle," Brookings Papers in Economic Activity 2, 1989, 1-49.

Paldam, M. (1979) "Is There An Electoral Cycle? A Comparative Study of National Accounts," Scandinavian Journal of Economics 81, 323-42.

Paldam, M. (1991), "How Robust is the Vote Function? A Study of Seventeen Nations Over Four Decades," in H. Norpoth, M.S. Lewis-Beck and J.D. Lafay, eds., Economics and Politics: The Calculus of Support, Ann Arbor: University of Michigan Press.

Peltzman, S. (1992), “Voters as Fiscal Conservatives," Quarterly Journal of Economics 107, 327 261.

Persson and Tabellini (1990), Macroeconomic Policy, Credibility, and Politics, London: Harwood.

Persson, T. and G. Tabellini (2003), The Economic Effect of Constitutions: What Do the Data Say?, Cambridge, MA: MIT Press.

Powell, Jr., G. B., and G. Whitten (1993), "A Cross-National Analysis of Economic Voting: Taking Account of the Political Context," American Journal of Political Science 37: 391414.

Rogoff, K. (1990), “Equilibrium Political Budget Cycles,” American Economic Review 80, 21 36.

Rogoff, K. and A. Sibert (1988), "Elections and Macroeconomic Policy Cycles," Review of Economic Studies 55, 1-16.

Roubini N. and J. Sachs (1989), "Political and Economic Determinants of Budget Deficits in the Industrial Democracies," European Economic Review 33, 903-38.

Shi, M. and J. Svensson (2002), "Political Budget Cycles in Developed and Developing Countries," working paper.

Shiller R.J. (1996), "Why Do People Dislike Inflation?, ” NBER working paper 5539.

Strøm, K. and S. M. Lipset (1984), "Macroeconomics and Macropolitics: The Electoral Performance of Democratic Governments," Paper presented at the Annual Meeting of the American Political Science Association, Washington, D.C.

Zárate, R.O. (2005), Zárate's Political Collections (ZPC) 1996-2005. 


\section{Data Appendix}

The data used in this study were collected from several sources covering economic, fiscal and political data. We also used information on institutional characteristics of countries, the timing of elections and data related to the party association and career circumstances of country leaders. The data sources which were used in this study are listed in Table A-1.

\section{The Sample}

The fiscal and economic data from the IFS and GFS are available for the years 1960-2003, and for many countries the period covered is shorter. We therefore restrict our sample to that period, even though election years and election results data are available for a longer period.

To restrict our sample only to democracies, we include only the years in which the country has a nonnegative score in the POLITY democracy index. That index is calculated as the sum of the scores that each country receives in each year on two scales: the degree of democracy (a 0 to 10 scale) and the degree of autocracy ( a 0 to -10 scale).

In the former socialist economies in Eastern Europe and the former Soviet Union we exclude the observations for the first two years after transition, as they may represent the simultaneous effect of the shift to democracy and the collapse of central planning, rather than political manipulation of fiscal variables. The countries and the years which are included in the sample are listed in Table A-2.

Our final sample, used for the estimation, consists only of election years in the sample period. The information on election dates were collected from the IDEA dataset "Voter Turnout Since 1945" and complemented by data from the CDP, IFES and the CIA's "World Factbook". ${ }^{22}$ In Presidential systems, we used only presidential elections and in Parliamentary systems only parliamentary ones. The identification of the political system was according to whether the chief executive responsible for economic policy is elected directly by the public (presidential) or by parliament (Parliamentary), as in Persson and Tabellini (2002). For example, France is defined as parliamentary since it is the government and the prime-minister- elected by the legislature - which are dominant in determining economic policy, rather than the president. These definitions are based on the variable SYSTEM in the DPI dataset. All the election years in the sample are listed in Table A-3.

\footnotetext{
${ }^{22}$ Additional sources that were used to complement the data on election dates were: Wikipedia, the free encyclopedia (www.wikipedia.org); African Elections Database http://africanelections.tripod.com/index.html) and Lijphart Elections Archive, in University of California, San Diego (http://dodgson.ucsd.edu/lii).
} 


\section{Fiscal Years}

In those countries in which the fiscal years are not the calendar years, we adjusted all the data to the fit the fiscal years. For example, in Canada the fiscal year starts on April $1^{\text {st }}$ and ends at March $31^{\text {st }}$ the following year. Hence, elections on March 2009 will be in the 2008 fiscal year. Data about fiscal years are from the IFS, supplemented by GFS data when information is missing in the IFS data.

\section{The Reelection Variable}

The dependent variable is Reelect - A binary variable receiving the value 1 if an incumbent leader is reelected in the elections. Data on the names of leaders and their party association were primarily based on ZPC data. The DPI provides data on the term of the leader in office, which allowed us to identify points of change in the leadership of the country, and whether those were election dates or not.

We built the variable in two different ways, constructing a narrow sample and an expanded one (in the expanded sample we add observations that were missing values in the Narrow Sample but we do not change any of the observations in the narrow sample).

The Narrow Sample includes observations in which:

* The leader has been in office, at least, in the two budgetary years preceding the election year.

* The leader stayed in office at least until one month before the elections; if he quits within the month before the elections Reelect receives the value 0 .

* There is no legal limit on the leader's term (based on the variable MULTPL in the DPI ${ }^{23}$ ), otherwise the observation is excluded. Data on legal limits on leaders' term in office are taken from the DPI.

The Expanded Sample also includes:

* Leaders who left their position less than 365 days before the elections In these cases Reelect receives the value 0 .

* Candidates replacing leaders that were subject to a legal limit, forcing them to quit at the end of their term. In these cases, Reelect receives the value 1 if the reigning leader's party is winning in the elections and 0 if it loses.

${ }^{23}$ For missing years we assumed that the legal limit remained as in the closest year in the sample. 
* Leaders replacing a previous leader who died in the election year or in the preceding it. In these cases the replacing leader is considered as continuing the original leader's term.

\section{Fiscal Policy Variables}

The fiscal policy variables are calculated on the basis of IFS variables, supplemented by GFS data when needed. In some cases we used alternative sources, as detailed in Brender and Drazen (2005c, the BOI discussion paper) Table A-I-1.

Balance is the difference between the central government's Total Revenue \& Grants and Total Expenditure (i.e., the fiscal surplus) for each country in each year. All these variables are presented as a percentage of GDP which is also taken from the IFS.

Using Balance we calculated BALCH_term, BALCH_ey and BALCH_term+ey, in the following way:

$\boldsymbol{B A} \boldsymbol{L}_{0}$ is the value of Balance in the election year and $\boldsymbol{B A L _ { - i }}$ is the value of Balance i years before the elections.

- $\boldsymbol{B A L C H}$ _term $=1 / 2 *\left(B A L_{-1}+B A L_{-2}\right)-1 / 2 *\left(B A L_{-3}+B A L_{-4}\right)$; which is the change in the average central government balance in the two years preceding the elections (not including the election year) compared to the previous two years.

* Where there are no data on $B A L_{-3}$ and $B A L_{-4}$ then: $B A L C H \_t e r m=B A L_{-1}-B A L_{-2}$

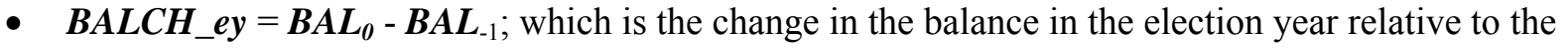
previous year.

- $\boldsymbol{B A L C H} \boldsymbol{H}_{-}$term + ey $=1 / 3 *\left(B \boldsymbol{A} \boldsymbol{L}_{0}+\boldsymbol{B} \boldsymbol{A} \boldsymbol{L}_{-1}+\boldsymbol{B} \boldsymbol{A} \boldsymbol{L}_{2}\right)-1 / 3 *\left(\boldsymbol{B A} \boldsymbol{L}_{-3}+\boldsymbol{B} \boldsymbol{A} \boldsymbol{L}_{-4}+\boldsymbol{B A} \boldsymbol{L}_{-5}\right) ;$ which is the change in the average balance to GDP ratio in the last 3 years of the term, including the elections year, compared to the previous 3 years.

* if there are no data on $B A L_{-3}, B A L_{-4}$ and $B A L_{-5}$ then:

BALCH_term $+e y=1 / 2 *\left(B A L_{0}+B A L_{-1}\right)-B A L_{-2}$

\section{Economic Variables}

The economic growth calculation is based on: GDPPC, real per-capita GDP for each country in each year, which is taken from the WDI dataset of the World Bank.

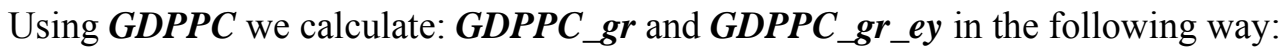


GDPPC $_{0}$ is the value of GDPPC in the election year, $G D P P C_{-1}$ is the value of GDPPC in the previous year and GDPPC $_{-x}$ is the value of GDPPC in the year in which the leader assumed his office (usually the previous election year), where $x$ is the number of years in office:

- $\boldsymbol{G D P P C}_{\mathbf{g}} \boldsymbol{g}=100 \bullet\left(\sqrt[x]{\left(\frac{\mathrm{GDPPC}_{0}}{\mathrm{GDPPC}_{-\mathrm{X}}}\right)}-1\right)$

- $\quad \boldsymbol{G D P P C} \_\boldsymbol{g} \boldsymbol{r}_{-} \boldsymbol{e y}=100 \bullet\left(\frac{\mathrm{GDPPC}_{0}}{\mathrm{GDPPC}_{-1}}-1\right)$

* In the Expanded sample $\boldsymbol{G D P P C}_{0}$ receives the value of $\boldsymbol{G D P P C}_{-1}$ if the leader left his office in the year preceding the election year.

\section{Economic Control Variables}

GDP_trend is the trend of real GDP (country specific) which was computed using the Hodrick-Prescott filter on the "GDP in constant 1995 US\$" series of the WDI. Using this variable we calculated for each country in every year the deviation of real GDP from its trend, and used it in the following way to compute the change in this deviation in the election year:

$\mathrm{GDP}_{0}$ and GDP trend $_{0}$ are the values of GDP and GDP_trend in the election year, and GDP - $_{-1}$ and GDP_trend ${ }_{-1}$ are the values of these variables in the year preceding the election year:

- $\boldsymbol{G D P D}$ _trend_ey $=\left(\frac{\mathrm{GDP}_{0}}{\mathrm{GDP} \text { trend }_{0}}-\frac{\mathrm{GDP}_{-1}}{\mathrm{GDP} \text { trend }_{-1}}\right)$

INF is the inflation rate for each country in each year, which is taken from the WDI dataset of the World Bank, supplemented by IFS data when needed.

Using INF we calculated INFCH_ey and Average_INF in the following way:

$\boldsymbol{I N F}_{\boldsymbol{0}}$ is the value of $\boldsymbol{I N F}$ in the election year, $\boldsymbol{I N F}_{-\boldsymbol{i}}$ is the value of $\boldsymbol{I N F}$ i years before the elections and $I_{\boldsymbol{I N}} \boldsymbol{F}_{-\mathrm{x}}$ is the value of $\mathbf{I N F}$ in the year in which the leader assumed his office (usually the previous election year), where $x$ is the number of years in office:

- INFCH_ey $=I_{N F_{0}}-I_{N F_{-1}}$; which is the change in the inflation rate in the election year relative to the previous year. 
- Average_INF $=100 \bullet\left(\sqrt[X]{\left[\prod_{\mathrm{i}=-\mathrm{X}+1}^{0}\left(1+\frac{\mathrm{INF}_{\mathrm{i}}}{100}\right)\right]}-1\right) ;$ which is the average inflation rate during the leader's term.

* In the Expanded sample $\mathbf{I N F}_{\mathbf{0}}$ receives the value of $\mathbf{I N F _ { - 1 }}$ if the leader left his office in the year preceding the election year.

In the final dataset we truncated the extreme values, and gave all values above the truncation point of a variable the value of the truncation point. The truncation points are:

For INF - in developed countries: $20 \%$, in less developed countries: $60 \%$.

For INFCH_ey - in less developed countries: 60\%.

For Average_INF - in less developed countries: 80\%.

In those cases where the inflation variable was truncated we added a binary variable with a value of 1 in the countries with high inflation. However, where these variables turned out not to be significant and not to affect the other coefficients, we dropped them from the final specification.

\section{Political Strength Control Variables}

The political strength variables for each country in each election year are mainly based on DPI data about the number of seats that the leader's party holds in parliament and the percent of votes that the president received in the previous elections (both in the first and the last rounds). These variables (GOVSEAT, OPPSEAT, PERCENT1, PERCENTL in DPI) are available for the period 1975-2000. For the other years: 1961-1975 and 2001-2003, we used data from IDEA and completed missing information from CDP:

PARTY - the percent of seats in the parliament held by the leader's party in the year preceding the election year. It receives the value 0 in a presidential system (in cases where data are from IDEA it is the proportion of the public's votes received by the party).

VOTES - the percent of votes for the leader in a presidential system in the first round of the previous elections; receives the value 0 in a parliamentary system.

VOTES_R2 - the percent of the votes for the leader in a presidential system in the last round of the previous elections (usually the second round); receives the value 0 in a parliamentary system and the value of VOTES if there was no second round. 
D_R2 - A binary variable receiving the value 1 for a leader in a presidential system who had to run in a second round in the previous elections.

\section{New vs. Old Democracies}

New_Democracy - A binary variable, for each country in each election year, receiving the value 1 for the period of the first 4 elections after a country with a negative polity value in the POLITY IV dataset shifted to non-negative values, not counting the elections in the transition year. Otherwise, the country is defined as an Old Democracy and the variable receives a value of 0 .

Old - A binary variable, for each country in each election year, receiving the value 1 if country is defined as an Old Democracy in that year. The years in which countries are defined as New Democracies are listed in Table A-2.

\section{Developed vs. Less Developed Countries}

Developed - A binary variable, for each country, receiving the value 1 for OECD economies that were members of the organization during the entire sample period.

Less_Developed - A binary variable, for each country, receiving the value 1 for all the countries that are not defined as developed. The Developed countries are listed in Table A-2.

\section{Presidential vs. Parliamentary Constitutional Rules}

Based on the constitutional rules defined above we calculated the following variables:

Pres - A binary variable, for each country in each election year, receiving the value 1 in a country with a Presidential system, and 0 otherwise.

Parl - A binary variable, for each country in each election year, receiving the value 1 in a country with a Parliamentary system, and 0 otherwise.

The constitutional rules of the various countries are listed in Table A-2.

\section{Proportional vs. Majoritarian Electoral Rules}

The DPI provides information, in each country and in each election year, whether candidates for presidency or parliament are elected based on the total share of votes received by their party or on the 
majority of votes in each voting zone (e.g., district). In the former case the electoral system is defined in the DPI as Proportional representation (PR in the DPI) and in the latter as Majoritarian representation.

Prop - A binary variable, for each country in each election year, receiving the value 1 in a country with a Proportional electoral system and 0 otherwise.

Maj - A binary variable, for each country in each election year, receiving the value 1 in a country with a Majoritarian electoral system, and 0 otherwise.

The electoral systems of the countries are listed in Table A-2.

\section{Level of Democracy}

We split the sample between countries with a polity score (in the DPI) of 0 to 9 and those with a score of 10. More than 50 percent of the data points represent countries with a score of 10 . Where the score changed during the covered period, we split the data points for that country according to the score in each year. Based on the distinction between the two levels we computed the following variables:

High - A binary variable, for each country in each election year, receiving the value 1 where the polity score is 10 .

Low - A binary variable, for each country in each election year, receiving the value 1 where the polity score is between 0 and 9 .

\section{Predetermined vs. Early Elections}

Based on the legally determined frequency of elections in a country (from the CIA's "World Factbook"), we identified when the next elections should have been held. If the elections were held in the expected year we classified them as predetermined; otherwise they were classified as early (or endogenous).

Pred - A binary variable, for each country in each election year, receiving the value 1 if the elections are defined as predetermined.

Early - A binary variable, for each country in each election year, receiving the value 1 if the elections are defined as early. 
Table A-1: Data Sources

\begin{tabular}{|c|c|c|c|c|c|}
\hline Source Name & Code & Dataset Producer & Date & Variables & \begin{tabular}{|l|} 
Available \\
Years \\
\end{tabular} \\
\hline International Financial Statistics & IFS & International Monetary Fund & 2003 & $\begin{array}{l}\text { central government total expenditure and } \\
\text { total revenue and grants; nominal GDP }\end{array}$ & $1960-2003$ \\
\hline Government Financial Statistics & GFS & International Monetary Fund & 2003 & $\begin{array}{l}\text { central government total expenditure and } \\
\text { total revenue and grants }\end{array}$ & $1960-2003$ \\
\hline World Development Indicators & WDI & The World Bank & 2003 & $\begin{array}{l}\text { GDP per capita in constant } 1995 \text { US\$, } \\
\text { GDP in constant } 1995 \text { US\$ }\end{array}$ & $1960-2003$ \\
\hline POLITY IV & POLITY & University of Maryland & 2003 & Level of Democracy index & $1800-2003$ \\
\hline Database of Political Institutions & DPI & The World Bank & 2000 & $\begin{array}{l}\text { political system, term limits, election } \\
\text { results and the allocation of seats in } \\
\text { parliament, election system. }\end{array}$ & $1975-2000$ \\
\hline $\begin{array}{l}\text { Voter Turnout Since } 1945 \text { to } \\
\text { Date }\end{array}$ & IDEA & $\begin{array}{l}\text { Institute for Democracy } \\
\text { and Electoral Assistance }\end{array}$ & Current & election years, election results & $1945-2001$ \\
\hline $\begin{array}{l}\text { The Center on Democratic } \\
\text { Performance }\end{array}$ & CDP & Binghamton University & Current & $\begin{array}{l}\text { election years, election results, election } \\
\text { dates }\end{array}$ & $1974-2000$ \\
\hline Electionguide.org & IFES & $\begin{array}{l}\text { International Foundation } \\
\text { for Electoral Systems }\end{array}$ & Current & election dates & $1998-2005$ \\
\hline World Political Leaders & ZPC & \begin{tabular}{|l|} 
Zárate's Political \\
Collections
\end{tabular} & Current & leaders' names and their party association & $1945-2005$ \\
\hline The World Factbook & $\mathrm{CIA}$ & Central Intelligence Agency & Current & $\begin{array}{l}\text { election dates, frequency of elections in } \\
\text { a country, political system }\end{array}$ & $1960-2005$ \\
\hline
\end{tabular}


Table A2: Sample Characteristics.

\begin{tabular}{|c|c|c|c|c|c|c|c|c|}
\hline No. & Country & $\begin{array}{l}\text { Years Included in the } \\
\text { Expanded Sample }\end{array}$ & $\begin{array}{l}\text { Elections in the } \\
\text { Narrow sample }\end{array}$ & $\begin{array}{l}\text { Additional Elections in } \\
\text { the Expanded sample }\end{array}$ & $\begin{array}{l}\text { Developed } \\
\text { Economy }\end{array}$ & $\begin{array}{l}\text { Parliamentary } \\
\text { System }\end{array}$ & $\begin{array}{l}\text { Proprotional } \\
\text { System }\end{array}$ & $\begin{array}{l}\text { Years as a New Democracy } \\
\text { in the Sample }\end{array}$ \\
\hline 1 & Argentina & $1983-2003$ & $3(3)$ & $1(1)$ & & & $x$ & $1983-2003$ \\
\hline 2 & Australia & $1961-2002$ & 13 & 1 & $X$ & $\mathrm{X}$ & $\mathrm{X}$ & \\
\hline 3 & Austria & 1960-1999 & 7 & 1 & $x$ & $x$ & $x$ & \\
\hline 4 & Belgium & 1960-1998 & 8 & 1 & $\mathrm{X}$ & $\mathrm{X}$ & $\mathrm{x}$ & \\
\hline 5 & Bolivia & $1985-2003$ & 0 & $4(3)$ & & & $x$ & 1982-1997 \\
\hline 6 & Brazil & 1985-1994 & 0 & $1(1)$ & & & $x$ & 1985-1994 \\
\hline 7 & Bulgaria & $1990-2003$ & $1(1)$ & 0 & & & $\mathrm{X}$ & $1990-2003$ \\
\hline 8 & Canada & $1965-2001$ & 7 & 2 & $\mathrm{x}$ & $\mathrm{X}$ & & \\
\hline 9 & Chile & $1960-1972,1989-2000$ & 0 & $3(2)$ & & & & $1989-2000$ \\
\hline 10 & Colombia & 1971-2003 & 0 & 7 & & & $\mathrm{X}$ & \\
\hline 11 & Costa Rica & 1972-2002 & 0 & 8 & & & $x$ & \\
\hline 12 & Cyprus & $1975-2003$ & $5(1)$ & 0 & & & $x$ & 1975-1983 \\
\hline 13 & Czech Republic & $1993-2003$ & $2(2)$ & 0 & & $\mathrm{X}$ & $x$ & 1993-2002 \\
\hline 14 & Denmark & $1960-2000$ & 11 & 0 & $\mathrm{X}$ & $x$ & $x$ & \\
\hline 15 & Dominican Republic & $1978-2000$ & $2(2)$ & $4(2)$ & & & $x$ & 1978-1994 \\
\hline 16 & Ecuador & $1979-2003$ & 0 & $5(4)$ & & & $x$ & 1979-1996 \\
\hline 17 & El Salvador & $1984-2000$ & 0 & $3(3)$ & & & $x$ & $1984-2000$ \\
\hline 18 & Estonia & 1991-2001 & 0 & $1(1)$ & & $\mathrm{X}$ & $x$ & $1991-2001$ \\
\hline 19 & Fiji & 1970-1986, 1990-1999 & $4(4)$ & 0 & & $x$ & & 1970-1986, 1990-1999 \\
\hline 20 & Finland & $1960-1998$ & 7 & 0 & $\mathrm{X}$ & $x$ & $\mathrm{x}$ & \\
\hline 21 & France & 1972-1997 & 5 & 0 & $x$ & $x$ & $\mathrm{X}+$ & \\
\hline 22 & Georgia & 1998-2002 & $1(1)$ & 0 & & & $x$ & 1998-2002 \\
\hline 23 & Germany & 1971-1998 & 6 & 1 & $x$ & $x$ & $x$ & \\
\hline 24 & Greece & 1960-1966, 1975-1999 & $4(2)$ & 1 & $x$ & $X^{*}$ & $x$ & $1975-1989$ \\
\hline 25 & Guatemala & 1966-1973, 1986-2003 & 0 & $4(4)$ & & & $x$ & 1966-1973, 1986-2003 \\
\hline 26 & Guyana & 1966-1979, 1992-1997 & $2(2)$ & $1(1)$ & & $X^{*}$ & $x$ & 1966-1979, 1992-1997 \\
\hline 27 & Honduras & $1982-2000$ & 0 & $3(3)$ & & & $\mathrm{X}$ & $1982-1997$ \\
\hline 28 & Hungary & $1990-2003$ & $2(2)$ & $1(1)$ & & $\mathrm{X}$ & $x$ & $1990-2003$ \\
\hline 29 & Iceland & 1972-2003 & 8 & 0 & $\mathrm{x}$ & $x$ & $x$ & \\
\hline 30 & India & $1960-2001$ & 5 & 3 & & $x$ & $x$ & 1960-1967 \\
\hline 31 & Ireland & $1960-2002$ & 10 & 0 & $\mathrm{X}$ & $x$ & $\mathrm{X}$ & \\
\hline 32 & Israel & $\begin{array}{l}\text { 1961-1972, 1974-1984, } \\
\text { 1986-2001 }\end{array}$ & 6 & 3 & & $X^{*}$ & $x$ & \\
\hline 33 & Italy & $1960-1998$ & 6 & 0 & $\mathrm{X}$ & $\mathrm{X}$ & $\mathrm{X}$ & \\
\hline 34 & Jamaica & $1975-1985,2000-2002$ & 2 & 0 & & $\mathrm{X}$ & & \\
\hline 35 & Japan & $1970-1993$ & 5 & 1 & $\mathrm{X}$ & $x$ & $\mathrm{X}$ & \\
\hline 36 & Korea & 1963-1971, 1988-1997 & $1(1)$ & $1(1)$ & & $X^{*}$ & $x$ & 1963-1971, 1988-1997 \\
\hline 37 & Lithuania & $1993-2002$ & $2(2)$ & 0 & & & $x$ & 1993-2002 \\
\hline 38 & Luxembourg & 1970-1974, 1976-1997 & 5 & 0 & $x$ & $x$ & $x$ & \\
\hline 39 & Madagascar & $1992-2001$ & $2(2)$ & 0 & & & $x$ & 1992-2001 \\
\hline
\end{tabular}


Table A2: Cont.

\begin{tabular}{|c|c|c|c|c|c|c|c|c|}
\hline No. & Country & $\begin{array}{l}\text { Years Included in the } \\
\text { Expanded Sample }\end{array}$ & $\begin{array}{l}\text { Elections in the } \\
\text { Narrow sample }\end{array}$ & $\begin{array}{l}\text { Additional Elections in } \\
\text { the Expanded sample }\end{array}$ & $\begin{array}{l}\text { Developed } \\
\text { Economy }\end{array}$ & $\begin{array}{l}\text { Parliamentary } \\
\text { System }\end{array}$ & $\begin{array}{l}\text { Proprotional } \\
\text { System }\end{array}$ & $\begin{array}{l}\text { Years as a New Democracy } \\
\text { in the Sample }\end{array}$ \\
\hline 40 & Malaysia & $1960-1999$ & $7(3)$ & 1 & & $\mathrm{X}$ & & $1960-1978$ \\
\hline 41 & Mali & $1992-2003$ & $1(1)$ & $1(1)$ & & & & $1992-2003$ \\
\hline 42 & Mauritius & 1981-2003 & 5 & 0 & & $x$ & & \\
\hline 43 & Mexico & $1988-2003$ & 0 & $2(2)$ & & & $\mathrm{X}$ & 1988-2003 \\
\hline 44 & Moldova & $1997-2001$ & $1(1)$ & 0 & & & $x$ & 1997-2001 \\
\hline 45 & Mongolia & 1990-1992, 1994-2003 & $2(2)$ & 0 & & & & $1990-2003$ \\
\hline 46 & Nepal & $1990-2001$ & $1(1)$ & 0 & & $\mathrm{X}$ & & 1990-2001 \\
\hline 47 & Netherlands & $1960-1998$ & 7 & 0 & $x$ & $\mathrm{x}$ & $\mathrm{x}$ & \\
\hline 48 & New zealand & $1960-1988,1990-2001$ & 10 & 2 & $x$ & $x$ & $\mathrm{X}+$ & \\
\hline 49 & Nicaragua & 1990-2003 & $2(2)$ & 0 & & & $x$ & $1990-2003$ \\
\hline 50 & Norway & $1960-2003$ & 5 & 2 & $X$ & $\mathrm{X}$ & $x$ & \\
\hline 51 & Pakistan & 1988-1998 & $2(2)$ & $1(1)$ & & $x$ & & 1988-1998 \\
\hline 52 & Panama & $1989-2000$ & 0 & $2(2)$ & & & $\mathrm{X}$ & $1989-2000$ \\
\hline 53 & Papua new Guinie & $1975-2002$ & $5(3)$ & 0 & & $x$ & & 1975-1992 \\
\hline 54 & Paraguay & $1989-2003$ & $2(2)$ & $1(1)$ & & & $x$ & 1989-2003 \\
\hline 55 & Peru & 1980-1999 & $1(1)$ & $2(2)$ & & & $x$ & 1980-1999 \\
\hline 56 & Philipines & $1960-1971,1987-2003$ & 2 & $1(1)$ & & & & $1987-2003$ \\
\hline 57 & Poland & $1991-2001$ & $2(2)$ & 0 & & & $x$ & 1989-2001 \\
\hline 58 & Portugal & 1976-1998 & $5(3)$ & 0 & $x$ & $X^{*}$ & $x$ & 1976-1987 \\
\hline 59 & Romania & $1990-2001$ & $1(1)$ & 0 & & $x$ & $x$ & $1990-2001$ \\
\hline 60 & Russia & 1995-2001 & 0 & $1(1)$ & & & $x$ & 1992-2001 \\
\hline 61 & Slovak Republic & $1994-2003$ & $2(2)$ & 0 & & $\mathrm{X}$ & $x$ & 1994-2003 \\
\hline 62 & Slovenia & $1993-2003$ & 0 & $1(1)$ & & $x$ & $x$ & $1993-2003$ \\
\hline 63 & Solomon Islands & 1978-1990, 1993-1999 & $2(1)$ & 0 & & $x$ & & 1978-1990 \\
\hline 64 & South Africa & 1994-2003 & 1 & 0 & & & $X$ & \\
\hline 65 & Spain & 1978-2003 & $5(2)$ & 0 & $x$ & $x$ & $x$ & 1978-1989 \\
\hline 66 & Sri Lanka & $1960-2001$ & $5(1)$ & 1 & & $X^{*}$ & $\mathrm{X}+$ & $1960-1965$ \\
\hline 67 & Sweden & $1961-2000$ & 10 & 1 & $x$ & $x$ & $x$ & \\
\hline 68 & Thailand & $1978-1990,1992-2003$ & $4(2)$ & 0 & & $x$ & & $1978-1990$ \\
\hline 69 & Trinidad \& Tobago & $\begin{array}{l}\text { 1962-1972, 1976-1989, } \\
1993-1995\end{array}$ & 3 & 1 & & $x$ & & \\
\hline 70 & Turkey & $1976-1979,1983-2001$ & $5(4)$ & 0 & $x$ & $x$ & $x$ & 1976-1979, 1983-1995 \\
\hline 71 & United Kindom & $1960-1999$ & 8 & 0 & $x$ & $x$ & & \\
\hline 72 & United States & $1960-2003$ & 7 & 3 & $x$ & & & \\
\hline 73 & Uruguay & $1985-2001$ & 0 & $2(2)$ & & & $x$ & 1985-2001 \\
\hline 74 & Venezuela & $1960-2001$ & 0 & $6(3)$ & & & $x$ & 1960-1978 \\
\hline
\end{tabular}

${ }^{1}$ The number in the parentheses indicates the number of elections that took place in a country during the years it is defined as a "new democracy".

* Some of the Elections are in a Presidential System

+ Some of the Elections are in a Majoritarian System 
Table A3: Detailed Sample and Data Characteristics.

\begin{tabular}{|c|c|c|c|c|c|c|c|}
\hline No. & Country & Election Years in the Narrow Sample & $\begin{array}{l}\text { Additional Election Years in the Expanded } \\
\text { Sample }\end{array}$ & $\begin{array}{l}\text { Cases in Which the Leader } \\
\text { was Reelected in the } \\
\text { Narrow Sample } \\
{ }^{1}\end{array}$ & $\begin{array}{l}\text { Additional Cases in Which } \\
\text { the Leader was Reelected in } \\
\text { the Expanded Sample }\end{array}$ & \begin{tabular}{|l} 
Budget \\
Balance
\end{tabular} & BALCH_ey ${ }^{3}$ \\
\hline 1 & Argentina & $1995,1999,2003$ & 1989 & $1 / 3$ & $0 / 1$ & -2.4 & 0.1 \\
\hline 2 & Australia & $\begin{array}{l}1964,1970,1973,1976,1978,1981,1983,1985, \\
1988,1990,1996,1999,2002\end{array}$ & 1967 & $9 / 13$ & $0 / 1$ & -0.8 & 0.0 \\
\hline 3 & Austria & $1966,1970,1979,1983,1990,1994,1999$ & 1986 & $4 / 7$ & $0 / 1$ & -4.3 & 0.2 \\
\hline 4 & Belgium & $1965,1968,1971,1977,1985,1987,1991,1995$ & 1981 & $6 / 8$ & $0 / 1$ & -5.3 & -0.2 \\
\hline 5 & Bolivia & | & $1989,1993,1997,2002$ & .. & $0 / 4$ & -3.5 & -1.9 \\
\hline 6 & Brazil & .. & 1994 & ... & $0 / 1$ & -3.3 & 4.2 \\
\hline 7 & Bulgaria & 2001 & 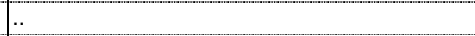 & $0 / 1$ & $0 / 0$ & -3.8 & 0.6 \\
\hline 8 & Canada & $1968,1972,1974,1979,1988,1997,2000$ & 1984, 1993 & $6 / 7$ & $0 / 2$ & -1.8 & 0.2 \\
\hline 9 & Chile & .. & 1970, 1993, 1999 & .. & $1 / 3$ & -1.1 & -1.8 \\
\hline 10 & Colombia & .. & $1974,1978,1982,1986,1990,1994,1998$ & .. & $3 / 7$ & -3.7 & 0.4 \\
\hline 11 & Costa Rica &.. & $\begin{array}{l}\text { 1974, 1978, 1982, 1986, 1990, 1994, 1998, } \\
2002\end{array}$ & .. & $3 / 8$ & 3.6 & -0.4 \\
\hline 12 & Cyprus & $1983,1988,1993,1998,2003$ &.. & $2 / 5$ & $0 / 0$ & -4.3 & -0.7 \\
\hline 13 & Czech Republic & 1996,2002 &.. & $1 / 2$ & $0 / 0$ & -1.4 & -0.2 \\
\hline 14 & Denmark & $\begin{array}{l}\text { 1964, 1966, 1968, 1971, 1975, 1977, 1979, 1984, } \\
1987,1990,1998\end{array}$ &.. & $8 / 11$ & $0 / 0$ & 0.7 & -0.2 \\
\hline 15 & Dominican Republic & 1990,1994 & $1982,1986,1996,2000$ & $2 / 2$ & $1 / 4$ & -0.3 & 0.2 \\
\hline 16 & Ecuador &.. & $1984,1988,1992,1996,2002$ & .. & $0 / 5$ & -0.4 & 1.1 \\
\hline 17 & El Salvador &.. & $1989,1994,1999$ & .. & $2 / 3$ & -1.4 & -0.2 \\
\hline 18 & Estonia & .. & 1995 & .. & $0 / 1$ & 0.8 & -2.5 \\
\hline 19 & Fiji & $1977,1982,1994,1999$ &.. & $3 / 4$ & $0 / 0$ & -3.8 & -1.8 \\
\hline 20 & Finland & $1966,1970,1975,1979,1987,1991,1995$ &.. & $0 / 7$ & $0 / 0$ & -0.6 & -1.3 \\
\hline 21 & France & $1978,1981,1986,1988,1997$ & .. & $1 / 5$ & $0 / 0$ & -1.8 & -0.3 \\
\hline 22 & Georgia & 2000 &.. & $1 / 1$ & $0 / 0$ & -1.3 & 0.6 \\
\hline 23 & Germany & $1976,1980,1987,1990,1994,1998$ & 1983 & $4 / 6$ & $0 / 1$ & -1.1 & 0.1 \\
\hline 24 & Greece & $1963,1985,1989,1993$ & 1996 & $1 / 4$ & $0 / 1$ & -5.8 & -1.8 \\
\hline 25 & Guatemala & & $1970,1995,1999,2003$ & .. & $0 / 4$ & -1.2 & -0.2 \\
\hline 26 & Guyana & 1968,1973 & 1997 & $2 / 2$ & $0 / 1$ & -8.2 & -4.2 \\
\hline 27 & Honduras & & $1989,1993,1997$ & & $1 / 3$ & -4.5 & -1.1 \\
\hline 28 & Hungary & 1998,2002 & 1994 & $0 / 2$ & $0 / 1$ & -5.0 & -2.0 \\
\hline 29 & Iceland & $1974,1978,1983,1987,1991,1995,1999,2003$ &.. & $3 / 8$ & $0 / 0$ & -1.1 & -0.4 \\
\hline 30 & India & $1970,1976,1989,1996,1999$ & $1967,1979,1984$ & $2 / 5$ & $2 / 3$ & -1.8 & -0.2 \\
\hline 31 & Ireland & $\begin{array}{l}1965,1969,1973,1977,1981,1987,1989,1992, \\
1997,2002\end{array}$ &.. & $4 / 10$ & $0 / 0$ & -5.8 & -0.3 \\
\hline 32 & Israel & $1965,1977,1981,1992,1999,2001$ & $1969,1984,1996$ & $2 / 6$ & $1 / 3$ & -6.0 & -0.2 \\
\hline 33 & Italy & $1963,1967,1972,1979,1987,1992$ &.. & $1 / 6$ & $0 / 0$ & -6.0 & 0.5 \\
\hline 34 & Jamaica & 1980,1983 &.. & $1 / 2$ & $0 / 0$ & -6.6 & -4.5 \\
\hline 35 & Japan & $1972,1976,1986,1989,1993$ & 1979 & $1 / 5$ & $0 / 1$ & -3.4 & -0.7 \\
\hline 36 & Korea & 1967 & 1997 & $1 / 1$ & $0 / 1$ & 1.2 & 0.1 \\
\hline 37 & Lithuania & 1997,2002 &.. & $0 / 2$ & $0 / 0$ & -1.9 & 0.5 \\
\hline 38 & Luxembourg & 1974, 1979, 1984, 1989, 1994 & .. & $1 / 5$ & $0 / 0$ & 2.7 & 0.8 \\
\hline 34 & Madagascar & 1996,2001 & ... & $0 / 2$ & $0 / 0$ & -4.4 & -0.2 \\
\hline 35 & Malaysia & $1969,1974,1978,1986,1990,1995,1999$ & 1982 & $7 / 7$ & $0 / 1$ & -4.5 & -0.8 \\
\hline 39 & Madagascar & 1996,2001 & & $0 / 2$ & $0 / 0$ & -4.4 & -0.2 \\
\hline 40 & Malaysia & $1969,1974,1978,1986,1990,1995,1999$ & 1982 & $7 / 7$ & $0 / 1$ & -4.5 & -0.8 \\
\hline 41 & Mali & 1997 & 2002 & $1 / 1$ & $0 / 1$ & -3.4 & 0.3 \\
\hline 42 & Mauritius & $1984,1988,1992,1996,2001$ & & $3 / 5$ & $0 / 0$ & -2.1 & -0.9 \\
\hline
\end{tabular}




\section{Table A3: Cont.}

\begin{tabular}{|c|c|c|c|c|c|c|c|}
\hline No. & Country & Election Years in the Narrow Sample & Sample & was Reelected in the & the Leader was Reelected in & Balance $^{2}$ & BALCH_ey ${ }^{3}$ \\
\hline 43 & Mexico & .. & 1994,2000 & .. & $1 / 2$ & -1.6 & -0.1 \\
\hline 44 & Moldova & 2001 &.. & $0 / 1$ & $0 / 0$ & -1.8 & 1.5 \\
\hline 45 & Mongolia & 1997,2001 & .. & $1 / 2$ & $0 / 0$ & -1.8 & 0.1 \\
\hline 46 & Nepal & 1995 & .. & $0 / 1$ & $0 / 0$ & -5.7 & 0.0 \\
\hline 47 & Netherlands & $1971,1977,1981,1986,1989,1994,1998$ & .. & $4 / 7$ & $0 / 0$ & -2.0 & 0.2 \\
\hline 48 & New zealand & $\begin{array}{l}\text { 1963, 1966, 1969, 1978, 1981, 1984, 1987, 1994, } \\
1997,2000\end{array}$ & 1972,1975 & $8 / 10$ & $0 / 2$ & -1.3 & -0.4 \\
\hline 49 & Nicaragua & 1996,2001 &.. & $0 / 2$ & $0 / 0$ & -2.6 & -1.8 \\
\hline 50 & Norway & $1965,1969,1985,1989,1993$ & 1981, 1997 & $3 / 5$ & $0 / 2$ & 2.9 & 0.6 \\
\hline 51 & Pakistan & 1991,1997 & 1994 & $2 / 2$ & $0 / 1$ & -5.9 & -0.8 \\
\hline 52 & Panama &.. & 1994,1999 & .. & $0 / 2$ & 0.5 & 0.1 \\
\hline 53 & Papua new Guinie & $1982,1987,1992,1997,2002$ &.. & $1 / 5$ & $0 / 0$ & -1.9 & -0.5 \\
\hline 54 & Paraguay & 1993,2003 & 1998 & $0 / 2$ & $1 / 1$ & -0.1 & 0.8 \\
\hline 55 & Peru & 1995 & 1985,1990 & $1 / 1$ & $0 / 2$ & -3.3 & -0.2 \\
\hline 56 & Philipines & 1965,1969 & 1998 & $1 / 2$ & $0 / 1$ & -1.3 & -1.8 \\
\hline 57 & Poland & 1995,2000 &.. & $1 / 2$ & $0 / 0$ & -3.5 & -0.2 \\
\hline 58 & Portugal & $1980,1985,1987,1991,1995$ & .. & $3 / 5$ & $0 / 0$ & -6.1 & -0.7 \\
\hline 59 & Romania & 1996 & .. & $0 / 1$ & $0 / 0$ & -2.3 & -1.3 \\
\hline 60 & Russia &.. & 2000 & .. & $0 / 1$ & -2.3 & 2.7 \\
\hline 61 & Slovak Republic & 1998,2002 &.. & $1 / 2$ & $0 / 0$ & -2.2 & -1.5 \\
\hline 62 & Slovenia &.. & 2000 &.. & $1 / 1$ & -1.0 & -0.6 \\
\hline 63 & Solomon Islands & 1989,1997 & .. & $0 / 2$ & $0 / 0$ & -4.0 & -3.0 \\
\hline 64 & South Africa & 1999 & .. & $0 / 1$ & $0 / 0$ & -3.1 & 0.4 \\
\hline 65 & Spain & $1986,1989,1993,1996,2000$ & .. & $4 / 5$ & $0 / 0$ & -3.6 & 0.6 \\
\hline 66 & Sri Lanka & $1965,1970,1977,1988,1999$ & 1994 & $1 / 5$ & $0 / 1$ & -7.4 & 0.4 \\
\hline 67 & Sweden & $\begin{array}{l}\text { 1965, 1969, 1974, 1977, 1983, 1986, 1989, 1992, } \\
1994,1998\end{array}$ & 1980 & $6 / 10$ & $0 / 1$ & 0.0 & 0.0 \\
\hline 68 & Thailand & $1983,1986,1995,2000$ &.. & $2 / 4$ & $0 / 0$ & -0.8 & 1.0 \\
\hline 69 & Trinidad \& Tobago & $1971,1986,1995$ & 1981 & $1 / 3$ & $1 / 1$ & -0.6 & -1.4 \\
\hline 70 & Turkey & $1977,1987,1991,1995,1999$ & .. & $2 / 5$ & $0 / 0$ & -5.8 & -2.1 \\
\hline 71 & United Kindom & $1966,1970,1974,1979,1983,1987,1992,1997$ &.. & $4 / 8$ & $0 / 0$ & -1.0 & 0.0 \\
\hline 72 & United States & $1968,1972,1976,1980,1984,1992,1996$ & $1964,1988,2000$ & $3 / 7$ & $2 / 3$ & -2.0 & 0.2 \\
\hline 73 & Uruguay & .. & 1994,1999 & .. & $1 / 2$ & -1.4 & -2.5 \\
\hline 74 & Venezuela & .. & $1968,1973,1978,1983,1993,1998$ & ... & $0 / 6$ & 1.5 & -0.9 \\
\hline
\end{tabular}

* Some of the Elections are in a Presidential System

+ Some of the Elections are in a Majoritarian System

${ }^{1}$ The figure on the left hand side is the number of elections where the leader was reelected. The figure on the right hand side is the total number of elections.

${ }^{2}$ Average for all the years included in the sample.

${ }^{3} \mathrm{BALCH}$ _ey -The average change in the government deficit ratio to GDP in the election year, compared to the previous year. 
Table 1: The Distribution of Election Campaigns According to Economic Development and the Age of Democracy ${ }^{1}$

\begin{tabular}{|c|c|c|c|}
\hline \multirow[b]{2}{*}{ Narrow Sample } & \multirow[t]{2}{*}{ Observations } & \multirow[t]{2}{*}{ Reelected } & \multirow[t]{2}{*}{ Not Reelected } \\
\hline & & & \\
\hline Less Developed Countries & 91 & 41 & 50 \\
\hline Developed Countries & 164 & 86 & 78 \\
\hline Old Democracies & 194 & 95 & 99 \\
\hline New Democracies & 61 & 32 & 29 \\
\hline Total & 255 & 127 & 128 \\
\hline \multicolumn{4}{|l|}{ Expanded Sample } \\
\hline Less Developed Countries & 167 & 60 & 107 \\
\hline Developed Countries & 180 & 88 & 92 \\
\hline Old Democracies & 242 & 107 & 135 \\
\hline New Democracies & 105 & 41 & 64 \\
\hline Total & 347 & 148 & 199 \\
\hline
\end{tabular}

${ }^{1}$ For a definition of the country categories see Appendix I. For a list of the countries in each category see Table A-2. 
Table 2: The Effects of Budget Balances and Growth on the Probability of Reelection in Developed and Less Developed Economies ${ }^{1}$

\begin{tabular}{|c|c|c|c|c|c|c|}
\hline \multirow{3}{*}{ Dependent variable: REELECT } & \multicolumn{3}{|c|}{ Narrow Sample } & \multicolumn{3}{|c|}{ Expanded Sample } \\
\hline & $(1)$ & \begin{tabular}{|l|}
$(2)$ \\
\end{tabular} & $(3)$ & $(4)$ & \begin{tabular}{|l|}
$(5)$ \\
\end{tabular} & $(6)$ \\
\hline & All Countries & Developed & Less Developed & All Countries & Developed & Less Developed \\
\hline BALCH_term ${ }^{2}$ & $\begin{array}{c}8.693^{\star \star} \\
{[0.033]}\end{array}$ & $\begin{array}{l}11.339 * * \\
{[0.026]}\end{array}$ & $\begin{array}{l}8.363 \\
{[0.268]}\end{array}$ & $\begin{array}{l}6.477^{\star \star} \\
{[0.040]}\end{array}$ & $\begin{array}{l}7.172 \\
{[0.108]}\end{array}$ & $\begin{array}{l}8.251 * \\
{[0.082]}\end{array}$ \\
\hline BALCH_ey ${ }^{2}$ & $\begin{array}{l}7.649 \star \\
{[0.095]}\end{array}$ & $\begin{array}{l}22.073^{\star \star \star} \\
{[0.001]}\end{array}$ & $\begin{array}{l}-4.248 \\
{[0.525]}\end{array}$ & $\begin{array}{l}6.097 \\
{[0.118]}\end{array}$ & $\begin{array}{l}19.390 * \star \star \\
{[0.003]}\end{array}$ & $\begin{array}{l}-0.521 \\
{[0.921]}\end{array}$ \\
\hline GDPPC_gr ${ }^{2}$ & $\begin{array}{l}10.869^{\star \star \star \star} \\
{[0.010]}\end{array}$ & $\begin{array}{l}-3.077 \\
{[0.615]}\end{array}$ & $\begin{array}{l}22.856^{\star \star \star} \\
{[0.001]}\end{array}$ & $\begin{array}{l}13.477^{\star \star *} \\
{[0.000]}\end{array}$ & $\begin{array}{l}-0.092 \\
{[0.988]}\end{array}$ & $\begin{array}{l}20.984^{\star * *} \\
{[0.000]}\end{array}$ \\
\hline Developed Countries & $\begin{array}{l}0.510^{* *} \\
{[0.019]}\end{array}$ & & & $\begin{array}{l}0.437^{\star \star} \\
{[0.011]}\end{array}$ & & \\
\hline New Democracies & $\begin{array}{l}0.467^{\star *} \\
{[0.045]}\end{array}$ & & & $\begin{array}{l}0.241 \\
{[0.197]}\end{array}$ & & \\
\hline Majoritarian Electoral System & $\begin{array}{l}0.508^{\star \star \star} \\
{[0.008]}\end{array}$ & $\begin{array}{l}0.360 \\
{[0.170]}\end{array}$ & $\begin{array}{l}0.494^{\star} \\
{[0.083]}\end{array}$ & $\begin{array}{l}0.471^{\star \star *} \\
{[0.004]}\end{array}$ & $\begin{array}{l}0.305 \\
{[0.197]}\end{array}$ & $\begin{array}{l}0.463^{\star *} \\
{[0.040]}\end{array}$ \\
\hline Constant & $\begin{array}{l}-0.845^{\star * \star} \\
{[0.001]}\end{array}$ & $\begin{array}{l}0.108 \\
{[0.597]}\end{array}$ & $\begin{array}{l}-0.974^{\star \star \star} \\
{[0.001]}\end{array}$ & $\begin{array}{l}-0.920 * * * \\
{[0.000]}\end{array}$ & $\begin{array}{l}-0.068 \\
{[0.730]}\end{array}$ & $\begin{array}{l}-0.999 * * * \\
{[0.000]}\end{array}$ \\
\hline Pseudo $\mathrm{R}^{2}$ & 0.068 & 0.072 & 0.125 & 0.076 & 0.057 & 0.117 \\
\hline Akaike's criteria & 343.34 & 220.59 & 119.65 & 451.48 & 245.28 & 202.63 \\
\hline Schwartz's criteria & 368.13 & 236.09 & 132.20 & 478.43 & 261.25 & 218.22 \\
\hline Observations & 255 & 164 & 91 & 347 & 180 & 167 \\
\hline
\end{tabular}

${ }^{1}$ For variables definitions see Appendix I. The figures in the table are probit coefficients and the figures in the parantheses are P-values.

${ }^{2}$ BALCH_term - The change in the ratio of the government deficit to GDP in the two years preceding the election year, relative to the two previous yearsBALCH_ey -The change in the government deficit ratio to GDP In the election year, compared to the previous year.GDPPC_gr - The average growth rate of real per-capita GDP during the leader's current term.

* - Significant at the 10 percent level; ** - Significant at the 5 percent level; ** - Significant at the 1 percent level. 
Table 3: Additional Effects of Election Year Budget Balances and Growth on the Probability of Reelection ${ }^{1}$

\begin{tabular}{|c|c|c|c|c|c|c|}
\hline \multirow{2}{*}{ Dependent variable: REELECT } & \multicolumn{4}{|c|}{ Narrow Sample } & \multicolumn{2}{|c|}{ Expanded Sample } \\
\hline & $(1)$ & $(2)$ & (3) & (4) & $(5)$ & $(6)$ \\
\hline BALCH_term * devloped ${ }^{2}$ & $\begin{array}{l}11.847^{\star \star} \\
{[0.020]}\end{array}$ & $\begin{array}{l}11.990 * * \\
{[0.020]}\end{array}$ & $\begin{array}{l}12.352^{\star *} \\
{[0.016]}\end{array}$ & & $\begin{array}{l}7.384^{*} \\
{[0.099]}\end{array}$ & \\
\hline BALCH_term * less_developed ${ }^{2}$ & $\begin{array}{l}10.796 \\
{[0.150]}\end{array}$ & $\begin{array}{l}9.603 \\
{[0.210]}\end{array}$ & $\begin{array}{l}7.441 \\
{[0.340]}\end{array}$ & & $\begin{array}{l}8.326^{*} \\
{[0.076]}\end{array}$ & \\
\hline BALCH_ey * developed ${ }^{2}$ & $\begin{array}{l}23.488^{\star \star \star} \\
{[0.001]}\end{array}$ & $\begin{array}{l}23.360^{\star \star \star} \\
{[0.002]}\end{array}$ & $\begin{array}{l}20.881^{\star \star \star} \\
{[0.007]}\end{array}$ & $\begin{array}{l}19.556^{\star \star \star} \\
{[0.004]}\end{array}$ & $\begin{array}{l}19.990^{\star \star \star} \\
{[0.002]}\end{array}$ & $\begin{array}{l}17.257^{\star \star \star} \\
{[0.007]}\end{array}$ \\
\hline BALCH_ey * less_developed ${ }^{2}$ & $\begin{array}{l}-3.991 \\
{[0.554]}\end{array}$ & $\begin{array}{l}-3.276 \\
{[0.642]}\end{array}$ & $\begin{array}{l}-2.639 \\
{[0.721]}\end{array}$ & $\begin{array}{l}-6.875 \\
{[0.311]}\end{array}$ & $\begin{array}{l}-0.719 \\
{[0.890]}\end{array}$ & $\begin{array}{l}-3.395 \\
{[0.505]}\end{array}$ \\
\hline GDPPC_gr * developed ${ }^{2}$ & $\begin{array}{l}-3.091 \\
{[0.615]}\end{array}$ & $\begin{array}{l}-3.639 \\
{[0.648]}\end{array}$ & $\begin{array}{l}-5.261 \\
{[0.421]}\end{array}$ & $\begin{array}{l}-4.766 \\
{[0.448]}\end{array}$ & $\begin{array}{l}0.152 \\
{[0.979]}\end{array}$ & $\begin{array}{l}-1.351 \\
{[0.822]}\end{array}$ \\
\hline GDPPC_gr * less_developed ${ }^{2}$ & $\begin{array}{l}23.245^{\star \star \star} \\
{[0.001]}\end{array}$ & $\begin{array}{l}36.461^{\star * \star} \\
{[0.000]}\end{array}$ & $\begin{array}{l}32.001^{\star * \star} \\
{[0.000]}\end{array}$ & $\begin{array}{l}21.742^{\star \star \star} \\
{[0.001]}\end{array}$ & $\begin{array}{l}21.449 * * * \\
{[0.000]}\end{array}$ & $\begin{array}{l}20.039 * * * \\
{[0.000]}\end{array}$ \\
\hline GDPPC_gr_ey * developed ${ }^{3}$ & & $\begin{array}{l}0.751 \\
{[0.906]}\end{array}$ & & & & \\
\hline GDPPC_gr_ey * less_developed ${ }^{3}$ & & $\begin{array}{l}-13.302^{\star *} \\
{[0.015]}\end{array}$ & & & & \\
\hline GDPD_trend_ey * developed ${ }^{4}$ & & & $\begin{array}{l}6.626 \\
{[0.336]}\end{array}$ & & & \\
\hline GDPD_trend_ey * less_developed ${ }^{4}$ & & & $\begin{array}{l}-17.224^{\star \star *} \\
{[0.003]}\end{array}$ & & & \\
\hline BALCH_term+ey * developed ${ }^{5}$ & & & & $\begin{array}{l}13.851^{\star \star \star} \\
{[0.003]}\end{array}$ & & $\begin{array}{l}10.089 * * \\
{[0.016]}\end{array}$ \\
\hline BALCH_term+ey * less_developed ${ }^{5}$ & & & & $\begin{array}{l}6.958 \\
{[0.288]}\end{array}$ & & $\begin{array}{l}6.217 \\
{[0.170]}\end{array}$ \\
\hline Developed Countries & $\begin{array}{l}1.338^{\star \star *} \\
{[0.000]}\end{array}$ & $\begin{array}{l}1.373^{\star \star *} \\
{[0.000]}\end{array}$ & $\begin{array}{l}1.651^{* \star *} \\
{[0.000]}\end{array}$ & $\begin{array}{l}1.345^{\star \star *} \\
{[0.000]}\end{array}$ & $\begin{array}{l}1.047^{\star \star \star} \\
{[0.000]}\end{array}$ & $\begin{array}{l}1.076^{\star \star \star} \\
{[0.000]}\end{array}$ \\
\hline New Democracies & $\begin{array}{l}0.537^{\star *} \\
{[0.026]}\end{array}$ & $\begin{array}{l}0.605^{\star \star} \\
{[0.015]}\end{array}$ & $\begin{array}{l}0.682^{\star \star \star} \\
{[0.009]}\end{array}$ & $\begin{array}{l}0.532^{\star *} \\
{[0.028]}\end{array}$ & $\begin{array}{l}0.286 \\
{[0.135]}\end{array}$ & $\begin{array}{l}0.296 \\
{[0.122]}\end{array}$ \\
\hline Majoritarian Electoral System & $\begin{array}{l}0.473^{\star *} \\
{[0.016]}\end{array}$ & $\begin{array}{l}0.502^{\star \star} \\
{[0.012]}\end{array}$ & $\begin{array}{l}0.459^{\star *} \\
{[0.023]}\end{array}$ & $\begin{array}{l}0.490 * * \\
{[0.012]}\end{array}$ & $\begin{array}{l}0.412^{\star *} \\
{[0.012]}\end{array}$ & $\begin{array}{l}0.424^{\star \star} \\
{[0.010]}\end{array}$ \\
\hline Constant & $\begin{array}{l}-1.282^{\star * *} \\
{[0.000]}\end{array}$ & $\begin{array}{l}-1.333^{\star * \star} \\
{[0.000]}\end{array}$ & $\begin{array}{l}-1.569 \star \star \star \\
{[0.000]}\end{array}$ & $\begin{array}{l}-1.236^{\star \star *} \\
{[0.000]}\end{array}$ & $\begin{array}{l}-1.159^{* \star *} \\
{[0.000]}\end{array}$ & $\begin{array}{l}-1.146^{\star \star \star} \\
{[0.000]}\end{array}$ \\
\hline Pseudo $\mathbf{R}^{2}$ & 0.108 & 0.127 & 0.143 & 0.116 & 0.101 & 0.105 \\
\hline Akaike's criteria & 335.32 & 332.65 & 324.41 & 332.46 & 445.89 & 444.03 \\
\hline Schwartz's criteria & 370.74 & 375.14 & 366.81 & 367.88 & 484.38 & 482.52 \\
\hline Observations & 255 & 255 & 253 & 255 & 347 & 347 \\
\hline
\end{tabular}

\footnotetext{
${ }^{1}$ For variables definitions see Appendix I. The figures in the table are probit coefficients and the figures in the parantheses are P-values. An asterisk (*) indicates multiplication by the binary variable that follows. developed - A binary variable with a value of 1 for developed countries, less_developed - A binary variable with a value of 1 for less developed countries.

${ }^{2}$ BALCH_term - The change in the ratio of the government deficit to GDP in the two years preceding the election year, relative to the two previous years. BALCH_ey -The change in the government deficit ratio to GDP In the election year, compared to the previous year. GDPPC_gr The average growth rate of real per-capita GDP during the leader's current term.

${ }^{3}$ GDPPC_gr_ey - Per-capita GDP growth in the last year of the leader's term.

${ }^{4}$ GDPD_trend_ey - The change in the deviation of real GDP from its trend, estimated using a Hodrick-Prescott filter, in the last year of the leader's term.

${ }^{5}$ BALCH_term+ey - The change in the budget balance ratio to GDP during the leader's term, including elections year.

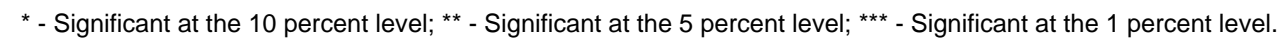


Table 4: Additional Effects of the Political System, the Timing of the Elections and the Level of Democracy on the Probability of Reelection ${ }^{1}$

\begin{tabular}{|c|c|c|c|c|c|c|}
\hline \multirow{2}{*}{ Dependent variable: REELECT } & \multicolumn{3}{|c|}{ Narrow Sample } & \multicolumn{3}{|c|}{ Expanded Sample } \\
\hline & \begin{tabular}{|l|}
$(1)$ \\
\end{tabular} & (2) & (3) & \begin{tabular}{|l|}
$(4)$ \\
\end{tabular} & (5) & (6) \\
\hline BALCH_term * developed ${ }^{2}$ & $\begin{array}{l}11.664^{\star *} \\
{[0.022]}\end{array}$ & $\begin{array}{l}12.200^{\star \star} \\
{[0.018]}\end{array}$ & $\begin{array}{l}11.842^{* *} \\
{[0.020]}\end{array}$ & $\begin{array}{l}7.237 \\
{[0.105]}\end{array}$ & $\begin{array}{l}7.530^{*} \\
{[0.093]}\end{array}$ & $\begin{array}{l}7.397^{\star} \\
{[0.098]}\end{array}$ \\
\hline BALCH_term * less_developed ${ }^{2}$ & $\begin{array}{l}10.964 \\
{[0.144]}\end{array}$ & $\begin{array}{l}10.252 \\
{[0.177]}\end{array}$ & $\begin{array}{l}10.762 \\
{[0.152]}\end{array}$ & $\begin{array}{l}8.953^{*} \\
{[0.061]}\end{array}$ & $\begin{array}{l}8.253^{\star} \\
{[0.078]}\end{array}$ & $\begin{array}{l}8.306^{\star} \\
{[0.077]}\end{array}$ \\
\hline BALCH_ey * developed ${ }^{2}$ & $\begin{array}{l}23.614^{\star \star \star} \\
{[0.001]}\end{array}$ & $\begin{array}{l}24.696^{\star \star \star} \\
{[0.000]}\end{array}$ & $\begin{array}{l}23.520^{\star * \star} \\
{[0.001]}\end{array}$ & $\begin{array}{l}20.262^{\star * *} \\
{[0.002]}\end{array}$ & $\begin{array}{l}20.430^{\star \star *} \\
{[0.002]}\end{array}$ & $\begin{array}{l}19.806^{\star \star \star} \\
{[0.002]}\end{array}$ \\
\hline BALCH_ey * less_developed ${ }^{2}$ & $\begin{array}{l}-2.837 \\
{[0.679]}\end{array}$ & $\begin{array}{l}-4.792 \\
{[0.481]}\end{array}$ & $\begin{array}{l}-4.006 \\
{[0.553]}\end{array}$ & $\begin{array}{l}0.822 \\
{[0.877]}\end{array}$ & $\begin{array}{l}-0.764 \\
{[0.883]}\end{array}$ & $\begin{array}{l}-0.511 \\
{[0.922]}\end{array}$ \\
\hline GDPPC_gr * developed ${ }^{2}$ & $\begin{array}{l}-3.335 \\
{[0.588]}\end{array}$ & $\begin{array}{l}-3.607 \\
{[0.558]}\end{array}$ & $\begin{array}{l}-3.082 \\
{[0.616]}\end{array}$ & $\begin{array}{l}-0.190 \\
{[0.974]}\end{array}$ & $\begin{array}{l}-0.052 \\
{[0.993]}\end{array}$ & $\begin{array}{l}0.108 \\
{[0.985]}\end{array}$ \\
\hline GDPPC_gr * less_developed ${ }^{2}$ & $\begin{array}{l}22.891^{\star \star *} \\
{[0.001]}\end{array}$ & $\begin{array}{l}23.753^{\star \star \star} \\
{[0.001]}\end{array}$ & $\begin{array}{l}23.250^{\star \star \star} \\
{[0.001]}\end{array}$ & $\begin{array}{l}20.595^{\star \star \star} \\
{[0.000]}\end{array}$ & $\begin{array}{l}21.653^{\star \star \star} \\
{[0.000]}\end{array}$ & $\begin{array}{l}21.393^{\star \star \star} \\
{[0.000]}\end{array}$ \\
\hline Parliamentary System ${ }^{3}$ & $\begin{array}{l}0.256 \\
{[0.303]}\end{array}$ & & & $\begin{array}{l}0.355^{\star} \\
{[0.065]}\end{array}$ & & \\
\hline Predetermined Elections ${ }^{3}$ & & $\begin{array}{l}-0.211 \\
{[0.225]}\end{array}$ & & & $\begin{array}{l}-0.088 \\
{[0.566]}\end{array}$ & \\
\hline High Level of Democracy ${ }^{3}$ & & & $\begin{array}{l}-0.019 \\
{[0.939]}\end{array}$ & & & $\begin{array}{l}0.108 \\
{[0.611]}\end{array}$ \\
\hline Developed Countries & $\begin{array}{l}1.264^{\star \star \star} \\
{[0.000]}\end{array}$ & $\begin{array}{l}1.362^{\star \star \star} \\
{[0.000]}\end{array}$ & $\begin{array}{l}1.347^{\star \star *} \\
{[0.000]}\end{array}$ & $\begin{array}{l}0.870^{\star \star \star} \\
{[0.002]}\end{array}$ & $\begin{array}{l}1.047^{\star \star \star} \\
{[0.000]}\end{array}$ & $\begin{array}{l}0.985^{\star * *} \\
{[0.001]}\end{array}$ \\
\hline New Democracies & $\begin{array}{l}0.578^{\star \star} \\
{[0.019]}\end{array}$ & $\begin{array}{l}0.548^{\star \star} \\
{[0.024]}\end{array}$ & $\begin{array}{l}0.533^{\star \star} \\
{[0.033]}\end{array}$ & $\begin{array}{l}0.333^{*} \\
{[0.086]}\end{array}$ & $\begin{array}{l}0.289 \\
{[0.131]}\end{array}$ & $\begin{array}{l}0.311 \\
{[0.115]}\end{array}$ \\
\hline Majoritarian Electoral System & $\begin{array}{l}0.456^{\star *} \\
{[0.021]}\end{array}$ & $\begin{array}{l}0.464^{\star \star} \\
{[0.018]}\end{array}$ & $\begin{array}{l}0.473^{\star *} \\
{[0.016]}\end{array}$ & $\begin{array}{l}0.363^{\star *} \\
{[0.030]}\end{array}$ & $\begin{array}{l}0.407^{\star *} \\
{[0.014]}\end{array}$ & $\begin{array}{l}0.413^{\star *} \\
{[0.012]}\end{array}$ \\
\hline Constant & $\begin{array}{l}-1.441^{\star \star \star} \\
{[0.000]}\end{array}$ & $\begin{array}{l}-1.164^{\star \star \star} \\
{[0.000]}\end{array}$ & $\begin{array}{l}-1.273^{\star \star \star} \\
{[0.000]}\end{array}$ & $\begin{array}{l}-1.294^{\star \star \star} \\
{[0.000]}\end{array}$ & $\begin{array}{l}-1.101^{\star \star *} \\
{[0.000]}\end{array}$ & $\begin{array}{l}-1.198^{\star \star \star} \\
{[0.000]}\end{array}$ \\
\hline Pseudo $\mathrm{R}^{2}$ & 0.111 & 0.112 & 0.108 & 0.108 & 0.101 & 0.101 \\
\hline Akaike's criteria & 336.26 & 335.84 & 337.32 & 444.46 & 447.56 & 447.63 \\
\hline Schwartz's criteria & 375.21 & 374.80 & 376.27 & 486.80 & 489.90 & 489.97 \\
\hline Observations & 255 & 255 & 255 & 347 & 347 & 347 \\
\hline
\end{tabular}

${ }^{1}$ For variables definitions see Appendix I. The figures in the table are probit coefficients and the figures in the parantheses are P-values. An asterisk $\left(^{*}\right)$ indicates multiplication by the binary variable that follows. developed - A binary variable with a value of 1 for developed countries, less_developed - A binary variable with a value of 1 for less developed countries.

${ }^{2}$ BALCH_term - The change in the ratio of the government deficit to GDP in the two years preceding the election year, relative to the two previous years. BALCH_ey -The change in the government deficit ratio to GDP In the election year, compared to the previous year. GDPPC_gr - The average growth rate of real per-capita GDP during the leader's current term.

${ }^{3}$ Binary variables indicating whether the country has a parliamentary political system, whether the elections took place in their predetermined date and whether the country was classified as having a high level of democracy in the year of the election campaign, respectively.

* - Significant at the 10 percent level; ** - Significant at the 5 percent level; ** - Significant at the 1 percent level. 
Table 5: Elasticities for Different Groups of Countries ${ }^{1}$

\begin{tabular}{|c|c|c|c|}
\hline Narrow Sample & BALCH_term ${ }^{2}$ & BALCH_ey ${ }^{2}$ & GDPPC_gr ${ }^{2}$ \\
\hline Developed Countries & 4.68 & 9.18 & .. \\
\hline Less Developed Countries & .. & .. & 9.24 \\
\hline Old Democracies & 4.27 & 4.13 & .. \\
\hline New Democracies & .. & .. & 8.69 \\
\hline Old \& Developed Democracies & 4.72 & 7.71 & .. \\
\hline Old \& Less Developed Democracies & .. & .. & 6.14 \\
\hline \multicolumn{4}{|l|}{ Expanded Sample } \\
\hline Developed Countries & 2.95 & 7.94 & .. \\
\hline Less Developed Countries & 3.09 & .. & 8.13 \\
\hline Old Democracies & 2.92 & 4.01 & 4.04 \\
\hline New Democracies & .. & .. & 7.05 \\
\hline Old \& Developed Democracies & 3.16 & 7.05 & .. \\
\hline Old \& Less Developed Democracies & .. & .. & 7.37 \\
\hline
\end{tabular}

\footnotetext{
${ }^{1}$ The elasticity is the change (in percentage points) in the probability for reelection for an increase of 1 percentage point in the variable country categories see Appendix I. For a list of the countries in each category see Table A-2.

${ }^{2}$ BALCH_term - The change in the ratio of the government deficit to GDP in the two years preceding the election year, relative to the BALCH_ey -The change in the government deficit ratio to GDP In the election year, compared to the previous year.GDPPC_gr - The : real per-capita GDP during the leader's current term.

".." - For coefficients with a significant level of more than 10 percent.
} 
Table 6: The Effects of Budget Balances and Growth on the Probability of Reelection in New and Old Democracies ${ }^{1}$

\begin{tabular}{|c|c|c|c|c|c|c|}
\hline \multirow{2}{*}{ Dependent variable: REELECT } & \multicolumn{3}{|c|}{ Narrow Sample } & \multicolumn{3}{|c|}{ Expanded Sample } \\
\hline & (1) & (2) & (3) & (4) & (5) & (6) \\
\hline BALCH_term * old ${ }^{2}$ & $\begin{array}{l}10.709^{\star \star} \\
{[0.018]}\end{array}$ & $\begin{array}{l}10.808^{\star *} \\
{[0.019]}\end{array}$ & & $\begin{array}{l}7.392^{\star \star} \\
{[0.042]}\end{array}$ & $\begin{array}{l}7.562^{\star \star} \\
{[0.040]}\end{array}$ & \\
\hline BALCH_term * new_democracy ${ }^{2}$ & $\begin{array}{l}0.559 \\
{[0.956]}\end{array}$ & $\begin{array}{l}1.085 \\
{[0.916]}\end{array}$ & & $\begin{array}{l}4.941 \\
{[0.431]}\end{array}$ & $\begin{array}{l}6.665 \\
{[0.307]}\end{array}$ & \\
\hline BALCH_ey * old ${ }^{2}$ & $\begin{array}{l}10.373^{\star} \\
{[0.078]}\end{array}$ & $\begin{array}{l}10.491^{*} \\
{[0.095]}\end{array}$ & $\begin{array}{l}6.789 \\
{[0.237]}\end{array}$ & $\begin{array}{l}10.135^{\star \star} \\
{[0.047]}\end{array}$ & $\begin{array}{l}9.784^{\star} \\
{[0.068]}\end{array}$ & $\begin{array}{l}7.469 \\
{[0.137]}\end{array}$ \\
\hline BALCH_ey * new_democracy ${ }^{2}$ & $\begin{array}{l}6.702 \\
{[0.361]}\end{array}$ & $\begin{array}{l}6.171 \\
{[0.412]}\end{array}$ & $\begin{array}{l}5.909 \\
{[0.464]}\end{array}$ & $\begin{array}{l}1.866 \\
{[0.761]}\end{array}$ & $\begin{array}{l}2.623 \\
{[0.677]}\end{array}$ & $\begin{array}{l}0.733 \\
{[0.908]}\end{array}$ \\
\hline GDPPC_gr * old $^{2}$ & $\begin{array}{l}6.330 \\
{[0.170]}\end{array}$ & $\begin{array}{l}4.969 \\
{[0.487]}\end{array}$ & $\begin{array}{l}5.069 \\
{[0.278]}\end{array}$ & $\begin{array}{l}10.204^{\star *} \\
{[0.011]}\end{array}$ & $\begin{array}{l}7.993 \\
{[0.196]}\end{array}$ & $\begin{array}{l}9.313^{\star *} \\
{[0.020]}\end{array}$ \\
\hline GDPPC_gr * new_democracy ${ }^{2}$ & $\begin{array}{l}22.064^{\star \star \star} \\
{[0.002]}\end{array}$ & $\begin{array}{l}28.463^{\star \star \star} \\
{[0.001]}\end{array}$ & $\begin{array}{l}21.514^{\star \star \star} \\
{[0.002]}\end{array}$ & $\begin{array}{l}18.088^{\star * \star} \\
{[0.001]}\end{array}$ & $\begin{array}{l}24.483^{\star \star \star} \\
{[0.000]}\end{array}$ & $\begin{array}{l}17.622^{\star \star *} \\
{[0.001]}\end{array}$ \\
\hline GDPPC_gr_ey * old ${ }^{3}$ & & $\begin{array}{l}0.728 \\
{[0.898]}\end{array}$ & & & $\begin{array}{l}1.731 \\
{[0.727]}\end{array}$ & \\
\hline GDPPC_gr_ey * new_democracy ${ }^{3}$ & & $\begin{array}{l}-8.168 \\
{[0.121]}\end{array}$ & & & $\begin{array}{l}-7.660^{*} \\
{[0.078]}\end{array}$ & \\
\hline BALCH_term+ey * old ${ }^{4}$ & & & $\begin{array}{l}11.746^{\star \star \star} \\
{[0.005]}\end{array}$ & & & $\begin{array}{l}9.233^{\star \star \star} \\
{[0.009]}\end{array}$ \\
\hline BALCH_term+ey * new_democracy ${ }^{4}$ & & & $\begin{array}{l}2.638 \\
{[0.759]}\end{array}$ & & & $\begin{array}{l}2.968 \\
{[0.614]}\end{array}$ \\
\hline Developed Countries & $\begin{array}{l}0.468^{\star \star} \\
{[0.020]}\end{array}$ & $\begin{array}{l}0.450^{\star *} \\
{[0.027]}\end{array}$ & $\begin{array}{l}0.483^{\star \star} \\
{[0.017]}\end{array}$ & $\begin{array}{l}0.413^{\star \star \star} \\
{[0.009]}\end{array}$ & $\begin{array}{l}0.401^{\star *} \\
{[0.011]}\end{array}$ & $\begin{array}{l}0.432^{\star \star \star} \\
{[0.006]}\end{array}$ \\
\hline Majoritarian Electoral System & $\begin{array}{l}0.489^{* *} \\
{[0.011]}\end{array}$ & $\begin{array}{l}0.487^{\star \star} \\
{[0.012]}\end{array}$ & $\begin{array}{l}0.499 * \star \star \\
{[0.009]}\end{array}$ & $\begin{array}{l}0.465^{\star \star \star} \\
{[0.004]}\end{array}$ & $\begin{array}{l}0.449^{\star \star \star} \\
{[0.006]}\end{array}$ & $\begin{array}{l}0.473^{\star \star \star} \\
{[0.004]}\end{array}$ \\
\hline Constant & $\begin{array}{l}-0.674^{\star \star \star} \\
{[0.002]}\end{array}$ & $\begin{array}{l}-0.635^{\star \star \star} \\
{[0.004]}\end{array}$ & $\begin{array}{l}-0.653^{\star \star \star} \\
{[0.003]}\end{array}$ & $\begin{array}{l}-0.808^{\star \star \star} \\
{[0.000]}\end{array}$ & $\begin{array}{l}-0.777^{\star \star \star} \\
{[0.000]}\end{array}$ & $\begin{array}{l}-0.803^{\star \star \star} \\
{[0.000]}\end{array}$ \\
\hline Pseudo $\mathbf{R}^{2}$ & 0.075 & 0.082 & 0.083 & 0.080 & 0.087 & 0.085 \\
\hline Akaike's criteria & 344.97 & 346.39 & 342.28 & 453.57 & 454.20 & 451.17 \\
\hline Schwartz's criteria & 376.84 & 385.34 & 374.15 & 488.21 & 496.54 & 485.81 \\
\hline Observations & 255 & 255 & 255 & 347 & 347 & 347 \\
\hline
\end{tabular}

${ }^{1}$ For variables definitions see Appendix I. The figures in the table are probit coefficients and the figures in the parantheses are P-values. An asterisk $\left(^{*}\right)$ indicates multiplication by the binary variable that follows. new_democracy - A binary variable with a value of 1 for new democracies, old - A binary variable with a value of 1 for old democracies.

${ }^{2}$ BALCH_term - The change in the ratio of the government deficit to GDP in the two years preceding the election year, relative to the two previous years. BALCH_ey -The change in the government deficit ratio to GDP In the election year, compared to the previous year. GDPPC_gr - The average growth rate of real per-capita GDP during the leader's current term.

${ }^{3}$ GDPPC_gr_ey - Per-capita GDP growth in the last year of the leader's term.

${ }^{4}$ BALCH_term+ey - The change in the budget balance ratio to GDP during the leader's term, including the elections year.

* - Significant at the 10 percent level; ** - Significant at the 5 percent level; *** - Significant at the 1 percent level. 
Table 7: The Effects of Budget Balances, Growth and Deviations of GDP from its trend on the Probability of Reelection in Developed, Less Developed and New Democracies ${ }^{1}$

\begin{tabular}{|c|c|c|c|c|}
\hline \multirow{2}{*}{ Dependent variable: REELECT } & \multicolumn{2}{|c|}{ Narrow Sample } & \multicolumn{2}{|c|}{ Expanded Sample } \\
\hline & $(1)$ & $(2)$ & (3) & (4) \\
\hline BALCH_term * old_developed ${ }^{2}$ & $\begin{array}{l}11.901 \text { ** } \\
{[0.021]}\end{array}$ & $\begin{array}{l}12.203^{\star *} \\
{[0.019]}\end{array}$ & $\begin{array}{l}7.920 * \\
{[0.081]}\end{array}$ & $\begin{array}{l}8.252^{*} \\
{[0.071]}\end{array}$ \\
\hline BALCH_term * old_less_developed ${ }^{2}$ & $\begin{array}{l}7.465 \\
{[0.475]}\end{array}$ & $\begin{array}{l}5.335 \\
{[0.620]}\end{array}$ & $\begin{array}{l}9.934 \\
{[0.148]}\end{array}$ & $\begin{array}{l}9.144 \\
{[0.185]}\end{array}$ \\
\hline BALCH_term * new_democracy ${ }^{2}$ & $\begin{array}{l}1.412 \\
{[0.891]}\end{array}$ & $\begin{array}{l}1.107 \\
{[0.916]}\end{array}$ & $\begin{array}{l}5.271 \\
{[0.415]}\end{array}$ & $\begin{array}{l}7.029 \\
{[0.313]}\end{array}$ \\
\hline BALCH_ey * old_developed ${ }^{2}$ & $\begin{array}{l}19.541^{\star \star \star} \\
{[0.007]}\end{array}$ & $\begin{array}{l}16.557^{* *} \\
{[0.049]}\end{array}$ & $\begin{array}{l}17.715^{\star \star \star} \\
{[0.008]}\end{array}$ & $\begin{array}{l}15.535^{\star \star} \\
{[0.041]}\end{array}$ \\
\hline BALCH_ey *old_less_developed ${ }^{2}$ & $\begin{array}{l}-6.703 \\
{[0.560]}\end{array}$ & $\begin{array}{l}-9.020 \\
{[0.488]}\end{array}$ & $\begin{array}{l}3.634 \\
{[0.666]}\end{array}$ & $\begin{array}{l}3.469 \\
{[0.698]}\end{array}$ \\
\hline BALCH_ey * new_democracy ${ }^{2}$ & $\begin{array}{l}6.327 \\
{[0.389]}\end{array}$ & $\begin{array}{l}7.323 \\
{[0.341]}\end{array}$ & $\begin{array}{l}1.914 \\
{[0.756]}\end{array}$ & $\begin{array}{l}4.116 \\
{[0.525]}\end{array}$ \\
\hline GDPPC_gr * old_developed ${ }^{2}$ & $\begin{array}{l}-1.128 \\
{[0.850]}\end{array}$ & $\begin{array}{l}-3.373 \\
{[0.601]}\end{array}$ & $\begin{array}{l}0.818 \\
{[0.887]}\end{array}$ & $\begin{array}{l}-1.146 \\
{[0.852]}\end{array}$ \\
\hline GDPPC_gr * old_less_developed ${ }^{2}$ & $\begin{array}{l}15.438 * * \\
{[0.034]}\end{array}$ & $\begin{array}{l}14.500 * \\
{[0.078]}\end{array}$ & $\begin{array}{l}19.265^{\star \star \star} \\
{[0.001]}\end{array}$ & $\begin{array}{l}19.006^{\star \star \star} \\
{[0.004]}\end{array}$ \\
\hline GDPPC_gr * new_democracy ${ }^{2}$ & $\begin{array}{l}25.385^{\star \star \star} \\
{[0.001]}\end{array}$ & $\begin{array}{l}27.705^{\star \star \star} \\
{[0.000]}\end{array}$ & $\begin{array}{l}20.657^{\star \star \star} \\
{[0.000]}\end{array}$ & $\begin{array}{l}23.419 * \star \star \\
{[0.000]}\end{array}$ \\
\hline GDPD_trend_ey * old_developed ${ }^{3}$ & & $\begin{array}{l}5.587 \\
{[0.454]}\end{array}$ & & $\begin{array}{l}4.528 \\
{[0.512]}\end{array}$ \\
\hline GDPD_trend_ey * old_less_developed ${ }^{3}$ & & $\begin{array}{l}0.085 \\
{[0.993]}\end{array}$ & & $\begin{array}{l}1.364 \\
{[0.855]}\end{array}$ \\
\hline GDPD_trend_ey * new_democracy ${ }^{3}$ & & $\begin{array}{l}-13.094^{\star \star} \\
{[0.023]}\end{array}$ & & $\begin{array}{l}-10.716^{\star \star} \\
{[0.016]}\end{array}$ \\
\hline Developed Countries & $\begin{array}{l}0.843^{\star \star *} \\
{[0.002]}\end{array}$ & $\begin{array}{l}0.863^{\star \star *} \\
{[0.003]}\end{array}$ & $\begin{array}{l}0.784^{\star * *} \\
{[0.000]}\end{array}$ & $\begin{array}{l}0.826^{\star \star *} \\
{[0.000]}\end{array}$ \\
\hline Majoritarian Electoral System & $\begin{array}{l}0.448^{\star \star} \\
{[0.022]}\end{array}$ & $\begin{array}{l}0.420 * * \\
{[0.036]}\end{array}$ & $\begin{array}{l}0.420 * \star \\
{[0.011]}\end{array}$ & $\begin{array}{l}0.361^{\star \star} \\
{[0.032]}\end{array}$ \\
\hline Constant & $\begin{array}{l}-0.857^{* \star \star} \\
{[0.000]}\end{array}$ & $\begin{array}{l}-0.827^{\star \star \star} \\
{[0.002]}\end{array}$ & $\begin{array}{l}-0.941^{\star \star \star} \\
{[0.000]}\end{array}$ & $\begin{array}{l}-0.932^{\star \star *} \\
{[0.000]}\end{array}$ \\
\hline Pseudo $\mathrm{R}^{2}$ & 0.093 & 0.112 & 0.093 & 0.112 \\
\hline Akaike's criteria & 344.59 & 341.57 & 453.13 & 449.834 \\
\hline Schwartz's criteria & 387.09 & 394.57 & 499.32 & 507.487 \\
\hline Observations & 255 & 253 & 347 & 345 \\
\hline
\end{tabular}

\footnotetext{
${ }^{1}$ For variables definitions see Appendix I. The figures in the table are probit coefficients and the figures in the parantheses are P-values. An asterisk (*) indicates multiplication by the binary variable that follows. new_democracy - A binary variable with a value of 1 for new democracies, old_developed - A binary variable with a value of 1 for old and developed democracies, old_less_developed - A binary variable with a value of 1 for old and less developed democracies.

${ }^{2}$ BALCH_term - The change in the ratio of the government deficit to GDP in the two years preceding the election year, relative to the two previous years. BALCH_ey -The change in the government deficit ratio to GDP In the election year, compared to the previous year. GDPPC_gr - The average growth rate of real per-capita GDP during the leader's current term.

${ }^{3}$ GDPD_trend_ey - The change in the difference between real GDP and its trend, estimated using a Hodrick-Prescott filter, in the last year of the leader's term.
}

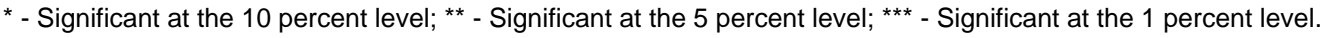


Table 8: Characteristics of Election Campaigns in Developed Countries and New Democracies

\begin{tabular}{|c|c|c|c|c|c|}
\hline Narrow Sample & Less Developed & Developed & Old & New & Total \\
\hline Observations & 91 & 164 & 194 & 61 & 255 \\
\hline Developed &.. &.. & 153 & 11 & 164 \\
\hline Less developed &.. &.. & 41 & 50 & 91 \\
\hline New & 50 & 11 & .. &.. & 61 \\
\hline Old & 41 & 153 &.. &.. & 194 \\
\hline Parliamentry & 57 & 154 & 175 & 36 & 211 \\
\hline Presidential & 34 & 10 & 19 & 25 & 44 \\
\hline Proportional & 48 & 133 & 140 & 41 & 181 \\
\hline Majoritarian & 43 & 31 & 54 & 20 & 74 \\
\hline $\begin{array}{l}\text { Predetermined } \\
\text { Election }\end{array}$ & 60 & 96 & 117 & 39 & 156 \\
\hline Early Election & 31 & 68 & 77 & 22 & 99 \\
\hline $\begin{array}{l}\text { High Level of } \\
\text { Democracy }\end{array}$ & 28 & 151 & 162 & 17 & 179 \\
\hline $\begin{array}{l}\text { Low Level of } \\
\text { Democracy }\end{array}$ & 63 & 13 & 32 & 44 & 76 \\
\hline \multicolumn{6}{|l|}{ Expanded Sample } \\
\hline Observations & 167 & 180 & 242 & 105 & 347 \\
\hline Developed &.. &.. & 169 & 11 & 180 \\
\hline Less developed &.. &.. & 73 & 94 & 167 \\
\hline New & 94 & 11 & .. & .. & 105 \\
\hline Old & 73 & 169 &.. & .. & 242 \\
\hline Parliamentry & 68 & 167 & 195 & 40 & 235 \\
\hline Presidential & 99 & 13 & 47 & 65 & 112 \\
\hline Proportional & 116 & 142 & 178 & 80 & 258 \\
\hline Majoritarian & 51 & 38 & 64 & 25 & 89 \\
\hline $\begin{array}{l}\text { Predetermined } \\
\text { Election }\end{array}$ & 120 & 106 & 152 & 74 & 226 \\
\hline Early Election & 47 & 74 & 90 & 31 & 121 \\
\hline $\begin{array}{l}\text { High Level of } \\
\text { Democracy }\end{array}$ & 40 & 167 & 186 & 21 & 207 \\
\hline $\begin{array}{l}\text { Low Level of } \\
\text { Democracy }\end{array}$ & 127 & 13 & 56 & 84 & 140 \\
\hline
\end{tabular}

\footnotetext{
${ }^{1}$ For definition of the various charactaristics see Appendix I. For a list of the country categories see table A-2.
} 
Table 9: Varying Effects of Budget Balances and Growth on the Probability of Reelection in Different Political and Electoral Systems: Developed and Less Developed Economies ${ }^{1}$

\begin{tabular}{|c|c|c|c|c|}
\hline \multirow{3}{*}{$\begin{array}{l}\text { Dependent variable: REELECT } \\
\text { Interaction Binary Variable: }\end{array}$} & \multicolumn{4}{|c|}{ Narrow Sample ${ }^{2}$} \\
\hline & \multicolumn{2}{|c|}{$(1)$} & \multicolumn{2}{|c|}{ (2) } \\
\hline & parl & pres & prop & maj \\
\hline BALCH_term * developed ${ }^{3}$ & $\begin{array}{l}12.152^{\star *} \\
{[0.019]}\end{array}$ & $\begin{array}{l}-3.824 \\
{[0.893]}\end{array}$ & $\begin{array}{l}13.606^{\star *} \\
{[0.018]}\end{array}$ & $\begin{array}{l}9.448 \\
{[0.445]}\end{array}$ \\
\hline BALCH_term * less_developed ${ }^{3}$ & $\begin{array}{l}16.809^{*} \\
{[0.065]}\end{array}$ & $\begin{array}{l}-6.118 \\
{[0.683]}\end{array}$ & $\begin{array}{l}-0.936 \\
{[0.932]}\end{array}$ & $\begin{array}{l}24.194^{\star *} \\
{[0.036]}\end{array}$ \\
\hline BALCH_ey * developed ${ }^{3}$ & $\begin{array}{l}24.023^{\star \star \star} \\
{[0.001]}\end{array}$ & $\begin{array}{l}17.776 \\
{[0.603]}\end{array}$ & $\begin{array}{l}29.313^{\star \star \star} \\
{[0.000]}\end{array}$ & $\begin{array}{l}2.269 \\
{[0.901]}\end{array}$ \\
\hline BALCH_ey * less_developed ${ }^{3}$ & $\begin{array}{l}-2.939 \\
{[0.691]}\end{array}$ & $\begin{array}{l}-3.891 \\
{[0.819]}\end{array}$ & $\begin{array}{l}-10.543 \\
{[0.282]}\end{array}$ & $\begin{array}{l}7.067 \\
{[0.503]}\end{array}$ \\
\hline GDPPC_gr * developed ${ }^{3}$ & $\begin{array}{l}-2.391 \\
{[0.700]}\end{array}$ & $\begin{array}{l}-25.574 \\
{[0.180]}\end{array}$ & $\begin{array}{l}-2.270 \\
{[0.719]}\end{array}$ & $\begin{array}{l}-19.795 \\
{[0.267]}\end{array}$ \\
\hline GDPPC_gr * less_developed ${ }^{3}$ & $\begin{array}{l}24.157^{\star \star \star} \\
{[0.001]}\end{array}$ & $\begin{array}{l}23.464^{\star *} \\
{[0.025]}\end{array}$ & $\begin{array}{l}24.836^{\star *} \\
{[0.016]}\end{array}$ & $\begin{array}{l}20.962^{\star *} \\
{[0.019]}\end{array}$ \\
\hline Developed Countries $^{4}$ & \multicolumn{2}{|c|}{$\begin{array}{c}1.406^{\star \star *} \\
{[0.000]}\end{array}$} & \multicolumn{2}{|c|}{$\begin{array}{c}1.507^{\star \star *} \\
{[0.000]}\end{array}$} \\
\hline New Democracies ${ }^{4}$ & \multicolumn{2}{|c|}{$\begin{array}{l}0.619^{* *} \\
{[0.014]}\end{array}$} & \multicolumn{2}{|c|}{$\begin{array}{l}0.584^{* *} \\
{[0.020]}\end{array}$} \\
\hline Majoritarian Electoral System ${ }^{4}$ & \multicolumn{2}{|c|}{$\begin{array}{l}0.513^{\star \star} \\
{[0.014]}\end{array}$} & \multicolumn{2}{|c|}{$\begin{array}{l}0.747^{*} \\
{[0.054]}\end{array}$} \\
\hline Constant & \multicolumn{2}{|c|}{$\begin{array}{c}-1.355^{\star \star \star} \\
{[0.000]}\end{array}$} & \multicolumn{2}{|c|}{$\begin{array}{c}-1.453^{\star \star \star} \\
{[0.000]}\end{array}$} \\
\hline Pseudo $\mathbf{R}^{2}$ & \multicolumn{2}{|c|}{0.118} & \multicolumn{2}{|c|}{0.131} \\
\hline Akaike's criteria & \multicolumn{2}{|c|}{343.64} & \multicolumn{2}{|c|}{339.07} \\
\hline Schwartz's criteria & \multicolumn{2}{|c|}{400.30} & \multicolumn{2}{|c|}{395.73} \\
\hline Observations & \multicolumn{2}{|c|}{255} & \multicolumn{2}{|c|}{255} \\
\hline
\end{tabular}

${ }^{1}$ For variables definitions see Appendix I. The figures in the table are probit coefficients and the figures in the parantheses are P-values. An asterisk (*) indicates multiplication by the binary variable that follows. developed - A binary variable with a value of 1 for developed countries, less_developed - A binary variable with a value of 1 for less developed countries.

2 There is no qualitative difference in the results when the equations are estimated for the expanded sample.

${ }^{3}$ BALCH_term - The change in the ratio of the government deficit to GDP in the two years preceding the election year, relative to the two previous years. BALCH_ey -The change in the government deficit ratio to GDP In the election year, compared to the previous year. GDPPC_gr - The average growth rate of real per-capita GDP during the leader's current term.

${ }^{4}$ The coefficients in each column are for the interaction of the variable on the top of column with the variable on the left column.

${ }^{5}$ The binary variables on the left column have no interaction with other variables.

* - Significant at the 10 percent level; ** - Significant at the 5 percent level; ${ }^{\star \star *}$ - Significant at the 1 percent level. 
Table 10: Varying Effects of Budget Balances and Growth on the Probability of Reelection According to theTiming of the Elections and the Level of Democracy: Developed and Less Developed Economies ${ }^{1}$

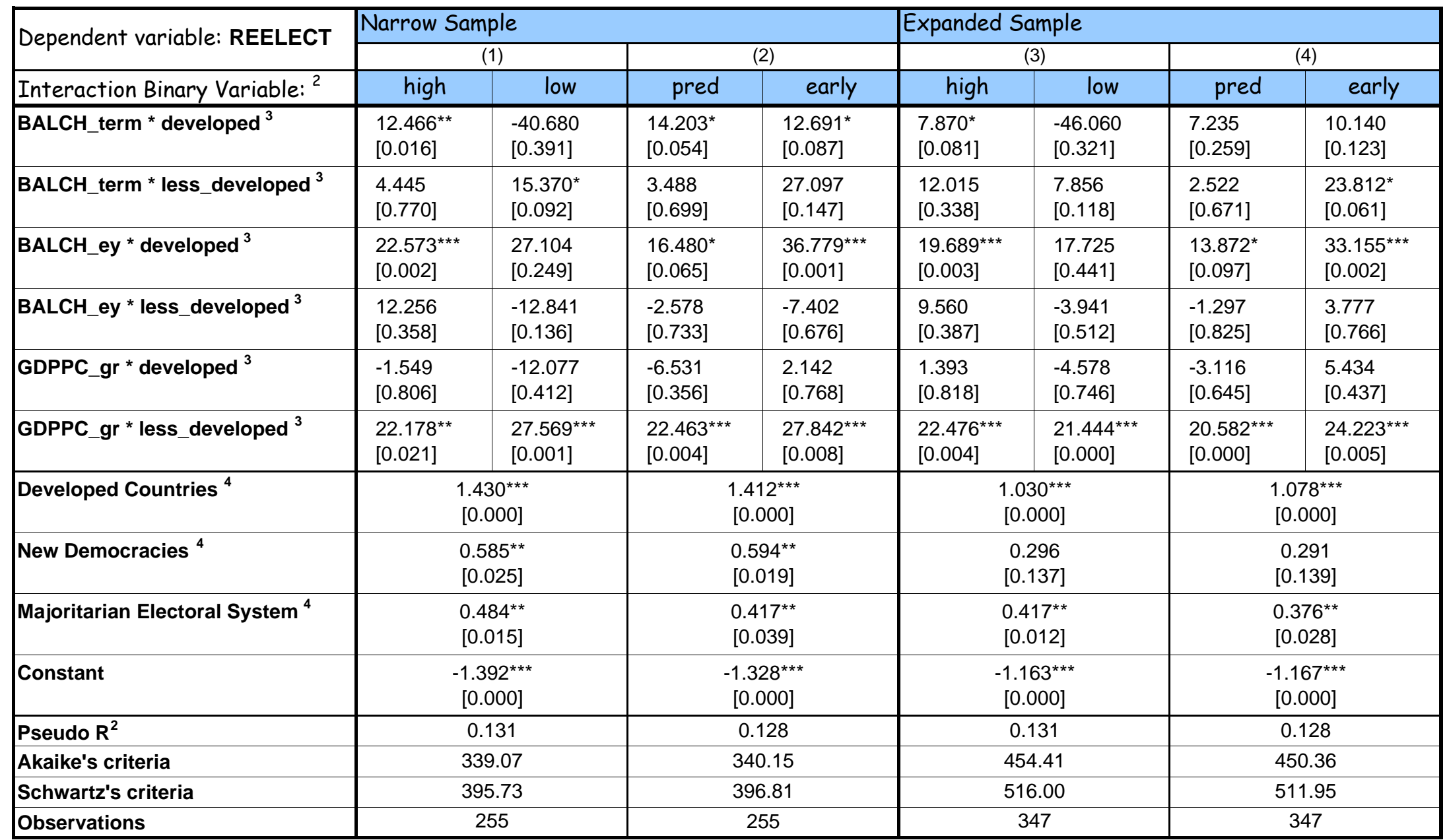

${ }^{1}$ For variables definitions see Appendix I. The figures in the table are probit coefficients and the figures in the parantheses are P-values. An asterisk ( $\left.{ }^{\star}\right)$ indicates multiplication by the binary variable that follows. developed - A binary variable with a value of 1 for developed countries, less_developed - A binary variable with a value of 1 for less developed countries.

${ }^{2}$ The coefficients in each column are for the interaction of the variable on the top of column with the variable on the left column.

${ }^{3}$ BALCH term - The change in the ratio of the government deficit to GDP in the two years preceding the election year, relative to the two previous years. BALCH ey -The change in the government deficit ratio to GDP In the election year, compared to the previous year. GDPPC_gr - The average growth rate of real per-capita GDP during the leader's current term.

${ }^{4}$ The binary variables on the left column have no interaction with other variables.

* - Significant at the 10 percent level; ** - Significant at the 5 percent level; *** - Significant at the 1 percent level. 
Table 11: Varying Effects of Budget Balances and Growth on the Probability of Reelection in Different Political and Electoral Systems: Old and New Democracies ${ }^{1}$

\begin{tabular}{|c|c|c|c|c|}
\hline \multirow{3}{*}{$\begin{array}{l}\text { Dependent variable: REELECT } \\
\text { Interaction Binary Variable: }^{2}\end{array}$} & \multicolumn{4}{|c|}{ Narrow Sample } \\
\hline & \multicolumn{2}{|c|}{ (1) } & \multicolumn{2}{|c|}{ (2) } \\
\hline & parl & pres & prop & maj \\
\hline BALCH_term ${ }^{*}$ old $^{3}$ & $\begin{array}{l}10.975^{\star \star} \\
{[0.019]}\end{array}$ & $\begin{array}{l}-10.278 \\
{[0.639]}\end{array}$ & $\begin{array}{l}10.021^{*} \\
{[0.064]}\end{array}$ & $\begin{array}{l}12.524 \\
{[0.136]}\end{array}$ \\
\hline BALCH_term * new_democracy ${ }^{3}$ & $\begin{array}{l}4.425 \\
{[0.738]}\end{array}$ & $\begin{array}{l}-7.270 \\
{[0.663]}\end{array}$ & $\begin{array}{l}-2.662 \\
{[0.818]}\end{array}$ & $\begin{array}{l}7.634 \\
{[0.737]}\end{array}$ \\
\hline BALCH_ey * old ${ }^{3}$ & $\begin{array}{l}10.051 * \\
{[0.098]}\end{array}$ & $\begin{array}{l}20.932 \\
{[0.396]}\end{array}$ & $\begin{array}{l}18.582^{* *} \\
{[0.013]}\end{array}$ & $\begin{array}{l}-5.289 \\
{[0.607]}\end{array}$ \\
\hline BALCH_ey* new_democracy ${ }^{3}$ & $\begin{array}{l}10.138 \\
{[0.205]}\end{array}$ & $\begin{array}{l}-13.683 \\
{[0.511]}\end{array}$ & $\begin{array}{l}0.484 \\
{[0.956]}\end{array}$ & $\begin{array}{l}22.160 \\
{[0.171]}\end{array}$ \\
\hline GDPPC_gr * old ${ }^{3}$ & $\begin{array}{l}7.129 \\
{[0.130]}\end{array}$ & $\begin{array}{l}-9.577 \\
{[0.445]}\end{array}$ & $\begin{array}{l}4.474 \\
{[0.429]}\end{array}$ & $\begin{array}{l}10.158 \\
{[0.215]}\end{array}$ \\
\hline GDPPC_gr * new_democracy ${ }^{3}$ & $\begin{array}{l}19.948 \text { ** } \\
{[0.017]}\end{array}$ & $\begin{array}{l}20.253^{*} \\
{[0.071]}\end{array}$ & $\begin{array}{l}17.161^{\star *} \\
{[0.030]}\end{array}$ & $\begin{array}{l}42.480 \text { ** } \\
{[0.017]}\end{array}$ \\
\hline Developed Countries ${ }^{4}$ & \multicolumn{2}{|c|}{$\begin{array}{c}0.393^{*} \\
{[0.061]}\end{array}$} & \multicolumn{2}{|c|}{$\begin{array}{l}0.529 * * \\
{[0.010]}\end{array}$} \\
\hline Majoritarian Electoral System ${ }^{4}$ & \multicolumn{2}{|c|}{$\begin{array}{l}0.492^{\star *} \\
{[0.012]}\end{array}$} & \multicolumn{2}{|c|}{$\begin{array}{c}0.250 \\
{[0.404]}\end{array}$} \\
\hline Constant & \multicolumn{2}{|c|}{$\begin{array}{c}-0.605^{\star \star *} \\
{[0.007]}\end{array}$} & \multicolumn{2}{|c|}{$\begin{array}{c}-0.662^{\star * \star} \\
{[0.004]}\end{array}$} \\
\hline Pseudo $\mathrm{R}^{2}$ & \multicolumn{2}{|c|}{0.087} & \multicolumn{2}{|c|}{0.095} \\
\hline Akaike's criteria & \multicolumn{2}{|c|}{352.59} & \multicolumn{2}{|c|}{349.85} \\
\hline Schwartz's criteria & \multicolumn{2}{|c|}{405.71} & \multicolumn{2}{|c|}{402.97} \\
\hline Observations & \multicolumn{2}{|c|}{255} & \multicolumn{2}{|c|}{255} \\
\hline
\end{tabular}

${ }^{1}$ For variables definitions see Appendix I. The figures in the table are probit coefficients and the figures in the parantheses are P-values. An asterisk $\left(^{*}\right)$ indicates multiplication by the binary variable that follows. new_democracy - A binary variable with a value of 1 for new democracies, old - A binary variable with a value of 1 for old democracies.

${ }^{2}$ The coefficients in each column are for the interaction of the variable on the top of column with the variable on the left column.

${ }^{3}$ BALCH_term - The change in the ratio of the government deficit to GDP in the two years preceding the election year, relative to the two previous years. BALCH_ey -The change in the government deficit ratio to GDP In the election year, compared to the previous year. GDPPC_gr - The average growth rate of real percapita GDP during the leader's current term.

${ }^{4}$ The binary variables on the left column have no interaction with other variables.

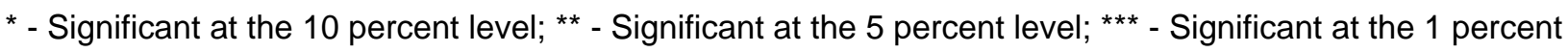
level. 
Table 12: Varying Effects of Budget Balances and Growth on the Probability of Reelection According to theTiming of the Elections and the Level of Democracy: Old and New Democracies ${ }^{1}$

\begin{tabular}{|c|c|c|c|c|c|c|c|c|}
\hline \multirow{3}{*}{$\begin{array}{l}\text { Dependent variable: REELECT } \\
\text { Interaction Binary Variable: }{ }^{2}\end{array}$} & \multicolumn{4}{|c|}{ Narrow Sample } & \multicolumn{4}{|c|}{ Expanded Sample } \\
\hline & \multicolumn{2}{|c|}{ (1) } & \multicolumn{2}{|c|}{$(2)$} & \multicolumn{2}{|c|}{ (3) } & \multicolumn{2}{|c|}{$(4)$} \\
\hline & high & low & pred & early & high & low & pred & early \\
\hline BALCH_term * old $^{3}$ & $\begin{array}{l}10.308^{\star *} \\
{[0.037]}\end{array}$ & $\begin{array}{l}6.448 \\
{[0.589]}\end{array}$ & $\begin{array}{l}9.176 \\
{[0.139]}\end{array}$ & $\begin{array}{l}13.998^{\star *} \\
{[0.044]}\end{array}$ & $\begin{array}{l}7.151 \\
{[0.101]}\end{array}$ & $\begin{array}{l}7.072 \\
{[0.318]}\end{array}$ & $\begin{array}{l}2.782 \\
{[0.577]}\end{array}$ & $\begin{array}{l}13.831 \text { ** } \\
{[0.021]}\end{array}$ \\
\hline BALCH_term * new_democracy ${ }^{3}$ & $\begin{array}{l}-2.495 \\
{[0.915]}\end{array}$ & $\begin{array}{l}7.734 \\
{[0.529]}\end{array}$ & $\begin{array}{l}1.831 \\
{[0.877]}\end{array}$ & $\begin{array}{l}11.508 \\
{[0.629]}\end{array}$ & $\begin{array}{l}10.578 \\
{[0.509]}\end{array}$ & $\begin{array}{l}5.205 \\
{[0.452]}\end{array}$ & $\begin{array}{l}4.973 \\
{[0.522]}\end{array}$ & $\begin{array}{l}7.408 \\
{[0.603]}\end{array}$ \\
\hline BALCH_ey * old ${ }^{3}$ & $\begin{array}{l}16.393^{\star *} \\
{[0.016]}\end{array}$ & $\begin{array}{l}-13.652 \\
{[0.312]}\end{array}$ & $\begin{array}{l}5.429 \\
{[0.457]}\end{array}$ & $\begin{array}{l}19.912^{\star *} \\
{[0.044]}\end{array}$ & $\begin{array}{l}14.271^{\star \star} \\
{[0.020]}\end{array}$ & $\begin{array}{l}1.464 \\
{[0.877]}\end{array}$ & $\begin{array}{l}6.934 \\
{[0.274]}\end{array}$ & $\begin{array}{l}17.332^{\star \star} \\
{[0.047]}\end{array}$ \\
\hline BALCH_ey * new_democracy ${ }^{3}$ & $\begin{array}{l}26.543 \\
{[0.111]}\end{array}$ & $\begin{array}{l}-2.786 \\
{[0.763]}\end{array}$ & $\begin{array}{l}3.507 \\
{[0.680]}\end{array}$ & $\begin{array}{l}25.063 \\
{[0.214]}\end{array}$ & $\begin{array}{l}20.476 \\
{[0.159]}\end{array}$ & $\begin{array}{l}-3.531 \\
{[0.627]}\end{array}$ & $\begin{array}{l}-2.725 \\
{[0.696]}\end{array}$ & $\begin{array}{l}20.658 \\
{[0.184]}\end{array}$ \\
\hline GDPPC_gr* old ${ }^{3}$ & $\begin{array}{l}6.397 \\
{[0.213]}\end{array}$ & $\begin{array}{l}6.627 \\
{[0.413]}\end{array}$ & $\begin{array}{l}3.700 \\
{[0.471]}\end{array}$ & $\begin{array}{l}9.290 \\
{[0.122]}\end{array}$ & $\begin{array}{l}8.514^{\star} \\
{[0.075]}\end{array}$ & $\begin{array}{l}12.686^{\star \star} \\
{[0.041]}\end{array}$ & $\begin{array}{l}8.708^{* *} \\
{[0.048]}\end{array}$ & $\begin{array}{l}12.124^{\star \star} \\
{[0.029]}\end{array}$ \\
\hline GDPPC_gr * new_democracy ${ }^{3}$ & $\begin{array}{l}23.931^{*} \\
{[0.070]}\end{array}$ & $\begin{array}{l}24.962 \text { *** } \\
{[0.002]}\end{array}$ & $\begin{array}{l}22.100^{\star * \star} \\
{[0.009]}\end{array}$ & $\begin{array}{l}20.596^{\star} \\
{[0.060]}\end{array}$ & $\begin{array}{l}24.756^{\star \star} \\
{[0.019]}\end{array}$ & $\begin{array}{l}17.576^{\star \star \star} \\
{[0.003]}\end{array}$ & $\begin{array}{l}15.930 \text { *** } \\
{[0.008]}\end{array}$ & $\begin{array}{l}22.229 * \star \\
{[0.022]}\end{array}$ \\
\hline Developed Countries $^{4}$ & \multicolumn{2}{|c|}{$\begin{array}{l}0.527^{* \star} \\
{[0.019]}\end{array}$} & \multicolumn{2}{|c|}{$\begin{array}{l}0.505^{\star \star} \\
{[0.015]}\end{array}$} & \multicolumn{2}{|c|}{$\begin{array}{c}0.471^{\star * \star} \\
{[0.009]}\end{array}$} & \multicolumn{2}{|c|}{$\begin{array}{c}0.426 * \star \star \\
{[0.008]}\end{array}$} \\
\hline Majoritarian Electoral System ${ }^{4}$ & \multicolumn{2}{|c|}{$\begin{array}{l}0.450 * * \\
{[0.021]}\end{array}$} & \multicolumn{2}{|c|}{$\begin{array}{l}0.468^{\star *} \\
{[0.017]}\end{array}$} & \multicolumn{2}{|c|}{$\begin{array}{c}0.441^{* * *} \\
{[0.007]}\end{array}$} & \multicolumn{2}{|c|}{$\begin{array}{c}0.429 * * \star \\
{[0.009]}\end{array}$} \\
\hline Constant & \multicolumn{2}{|c|}{$\begin{array}{c}-0.739 * * \star \\
{[0.001]}\end{array}$} & \multicolumn{2}{|c|}{$\begin{array}{c}-0.671^{\star \star \star} \\
{[0.002]}\end{array}$} & \multicolumn{2}{|c|}{$\begin{array}{c}-0.826^{\star \star \star} \\
{[0.000]}\end{array}$} & \multicolumn{2}{|c|}{$\begin{array}{c}-0.789 * \star \star \\
{[0.000]}\end{array}$} \\
\hline Pseudo $\mathrm{R}^{2}$ & \multicolumn{2}{|c|}{0.098} & \multicolumn{2}{|c|}{0.085} & \multicolumn{2}{|c|}{0.098} & \multicolumn{2}{|c|}{0.085} \\
\hline Akaike's criteria & \multicolumn{2}{|c|}{348.74} & \multicolumn{2}{|c|}{353.34} & \multicolumn{2}{|c|}{461.37} & \multicolumn{2}{|c|}{460.48} \\
\hline Schwartz's criteria & \multicolumn{2}{|c|}{401.86} & \multicolumn{2}{|c|}{406.46} & \multicolumn{2}{|c|}{519.11} & \multicolumn{2}{|c|}{518.22} \\
\hline Observations & \multicolumn{2}{|c|}{255} & \multicolumn{2}{|c|}{255} & \multicolumn{2}{|c|}{347} & \multicolumn{2}{|c|}{347} \\
\hline
\end{tabular}

${ }^{1}$ For variables definitions see Appendix I. The figures in the table are probit coefficients and the figures in the parantheses are P-values. An asterisk ( ${ }^{\star}$ ) indicates multiplication by the binary variable that follows. new_democracy - A binary variable with a value of 1 for new democracies, old - A binary variable with a value of 1 for old democracies.

${ }^{2}$ The coefficients in each column are for the interaction of the variable on the top of column with the variable on the left column.

${ }^{3}$ BALCH_term - The change in the ratio of the government deficit to GDP in the two years preceding the election year, relative to the two previous yearsBALCH_ey -The change in the government deficit ratio to GDP In the election year, compared to the previous year.GDPPC_gr - The average growth rate of real per-capita GDP during the leader's current term.

${ }^{4}$ The binary variables on the left column have no interaction with other variables.

* - Significant at the 10 percent level; ** - Significant at the 5 percent level; ${ }^{* \star \star}$ - Significant at the 1 percent level. 
Table 13: Varying Effects of Budget Balances and Growth on the Probability of Reelection in Different Political and Electoral Systems: Developed, Less Developed and New Democracies ${ }^{1}$

\begin{tabular}{|c|c|c|c|c|}
\hline \multirow{3}{*}{$\begin{array}{l}\text { Dependent variable: REELECT } \\
\text { Interaction Binary Variable: }^{2}\end{array}$} & \multicolumn{4}{|c|}{ Narrow Sample } \\
\hline & \multicolumn{2}{|c|}{ (1) } & \multicolumn{2}{|c|}{ (2) } \\
\hline & parl & pres & prop & maj \\
\hline BALCH_term * old_developed ${ }^{3}$ & $\begin{array}{l}11.522^{\star \star} \\
{[0.028]}\end{array}$ & $\begin{array}{l}26.626 \\
{[0.479]}\end{array}$ & $\begin{array}{l}13.825^{\star \star} \\
{[0.019]}\end{array}$ & $\begin{array}{l}8.346 \\
{[0.488]}\end{array}$ \\
\hline BALCH_term * old_less_developed ${ }^{3}$ & $\begin{array}{l}9.057 \\
{[0.442]}\end{array}$ & $\begin{array}{l}-25.632 \\
{[0.424]}\end{array}$ & $\begin{array}{l}-16.044 \\
{[0.456]}\end{array}$ & $\begin{array}{l}20.069 \\
{[0.151]}\end{array}$ \\
\hline BALCH_term * new_democracy ${ }^{3}$ & $\begin{array}{l}3.694 \\
{[0.784]}\end{array}$ & $\begin{array}{l}-4.801 \\
{[0.779]}\end{array}$ & $\begin{array}{l}-1.995 \\
{[0.867]}\end{array}$ & $\begin{array}{l}8.019 \\
{[0.724]}\end{array}$ \\
\hline BALCH_ey * old_developed ${ }^{3}$ & $\begin{array}{l}18.424^{\star *} \\
{[0.012]}\end{array}$ & $\begin{array}{l}90.815 \\
{[0.163]}\end{array}$ & $\begin{array}{l}25.693^{\star \star \star} \\
{[0.002]}\end{array}$ & $\begin{array}{l}-2.152 \\
{[0.902]}\end{array}$ \\
\hline BALCH_ey * old_less_developed ${ }^{3}$ & $\begin{array}{l}-6.746 \\
{[0.605]}\end{array}$ & $\begin{array}{l}7.854 \\
{[0.768]}\end{array}$ & $\begin{array}{l}-16.571 \\
{[0.422]}\end{array}$ & $\begin{array}{l}-0.565 \\
{[0.969]}\end{array}$ \\
\hline BALCH_ey * new_democracy ${ }^{3}$ & $\begin{array}{l}8.897 \\
{[0.265]}\end{array}$ & $\begin{array}{l}-12.319 \\
{[0.566]}\end{array}$ & $\begin{array}{l}-0.082 \\
{[0.993]}\end{array}$ & $\begin{array}{l}21.362 \\
{[0.188]}\end{array}$ \\
\hline GDPPC_gr * old_developed ${ }^{3}$ & $\begin{array}{l}-0.191 \\
{[0.975]}\end{array}$ & $\begin{array}{l}-38.708 \\
{[0.166]}\end{array}$ & $\begin{array}{l}-0.973 \\
{[0.875]}\end{array}$ & $\begin{array}{l}-6.382 \\
{[0.706]}\end{array}$ \\
\hline GDPPC_gr * old_less_developed ${ }^{3}$ & $\begin{array}{l}15.906^{\star *} \\
{[0.040]}\end{array}$ & $\begin{array}{l}5.846 \\
{[0.716]}\end{array}$ & $\begin{array}{l}18.589 \\
{[0.144]}\end{array}$ & $\begin{array}{l}13.551 \\
{[0.131]}\end{array}$ \\
\hline GDPPC_gr * new_democracy ${ }^{3}$ & $\begin{array}{l}23.114^{\star \star \star} \\
{[0.008]}\end{array}$ & $\begin{array}{l}25.858^{\star \star} \\
{[0.030]}\end{array}$ & $\begin{array}{l}21.162^{\star *} \\
{[0.015]}\end{array}$ & $\begin{array}{l}44.924^{\star *} \\
{[0.016]}\end{array}$ \\
\hline Developed Countries $^{4}$ & \multicolumn{2}{|c|}{$\begin{array}{c}0.841^{\star * \star} \\
{[0.003]}\end{array}$} & \multicolumn{2}{|c|}{$\begin{array}{c}0.936^{\star \star \star} \\
{[0.002]}\end{array}$} \\
\hline Majoritarian Electoral System ${ }^{4}$ & \multicolumn{2}{|c|}{$\begin{array}{l}0.527^{\star *} \\
{[0.013]}\end{array}$} & \multicolumn{2}{|c|}{$\begin{array}{c}0.446 \\
{[0.230]}\end{array}$} \\
\hline Constant & \multicolumn{2}{|c|}{$\begin{array}{c}-0.857^{\star * *} \\
{[0.001]}\end{array}$} & \multicolumn{2}{|c|}{$\begin{array}{c}-0.934^{\star \star *} \\
{[0.002]}\end{array}$} \\
\hline Pseudo $\mathbf{R}^{2}$ & \multicolumn{2}{|c|}{0.114} & \multicolumn{2}{|c|}{0.119} \\
\hline Akaike's criteria & \multicolumn{2}{|c|}{355.26} & \multicolumn{2}{|c|}{353.55} \\
\hline Schwartz's criteria & \multicolumn{2}{|c|}{429.62} & \multicolumn{2}{|c|}{427.92} \\
\hline Observations & \multicolumn{2}{|c|}{255} & \multicolumn{2}{|c|}{255} \\
\hline
\end{tabular}

${ }^{1}$ For variables definitions see Appendix I. The figures in the table are probit coefficients and the figures in the parantheses are Pvalues. An asterisk $\left(^{*}\right)$ indicates multiplication by the binary variable that follows. new_democracy - A binary variable with a value of 1 for new democracies, old_developed - A binary variable with a value of 1 for old and developed democracies, old_less_developed - A binary variable with a value of 1 for old and less developed democracies.

${ }^{2}$ The coefficients in each column are for the interaction of the variable on the top of column with the variable on the left column.

${ }^{3}$ BALCH_term - The change in the ratio of the government deficit to GDP in the two years preceding the election year, relative to the two previous years. BALCH_ey -The change in the government deficit ratio to GDP In the election year, compared to the previous year. GDPPC_gr - The average growth rate of real per-capita GDP during the leader's current term.

${ }^{4}$ The binary variables on the left column have no interaction with other variables.

* - Significant at the 10 percent level; ** - Significant at the 5 percent level; ** - Significant at the 1 percent level. 
Table 14: Varying Effects of Budget Balances and Growth on the Probability of Reelection According to theTiming of the Elections and the Level of Democracy: Developed, Less Developed and New Democracies ${ }^{1}$

\begin{tabular}{|c|c|c|c|c|c|c|c|c|}
\hline \multirow{3}{*}{$\begin{array}{l}\text { Dependent variable: REELECT } \\
\text { Interaction Binary Variable: }^{2}\end{array}$} & \multicolumn{4}{|c|}{ Narrow Sample } & \multicolumn{4}{|c|}{ Expanded Sample } \\
\hline & \multicolumn{2}{|c|}{$\begin{array}{r}(1) \\
(1)\end{array}$} & \multicolumn{2}{|c|}{ (2) } & \multicolumn{2}{|c|}{\begin{tabular}{|c|}
$(3)$ \\
\end{tabular}} & \multicolumn{2}{|c|}{ (4) } \\
\hline & high & low & pred & early & high & low & pred & early \\
\hline BALCH_term * old_developed ${ }^{3}$ & $\begin{array}{l}12.280^{* *} \\
{[0.018]}\end{array}$ & $\begin{array}{l}-147.115 \\
{[0.342]}\end{array}$ & $\begin{array}{l}14.738^{* *} \\
{[0.048]}\end{array}$ & $\begin{array}{l}11.404 \\
{[0.124]}\end{array}$ & $\begin{array}{l}8.138^{*} \\
{[0.074]}\end{array}$ & $\begin{array}{l}-138.309 \\
{[0.380]}\end{array}$ & $\begin{array}{l}8.154 \\
{[0.208]}\end{array}$ & $\begin{array}{l}9.579 \\
{[0.147]}\end{array}$ \\
\hline BALCH_term * old_less_dev ${ }^{3}$ & $\begin{array}{l}6.105 \\
{[0.762]}\end{array}$ & $\begin{array}{l}4.034 \\
{[0.754]}\end{array}$ & $\begin{array}{l}-7.216 \\
{[0.609]}\end{array}$ & $\begin{array}{l}42.565 \\
{[0.159]}\end{array}$ & $\begin{array}{l}11.503 \\
{[0.519]}\end{array}$ & $\begin{array}{l}8.832 \\
{[0.233]}\end{array}$ & $\begin{array}{l}-1.685 \\
{[0.865]}\end{array}$ & $\begin{array}{l}43.530^{*} \\
{[0.085]}\end{array}$ \\
\hline BALCH_term * new_democracy ${ }^{3}$ & $\begin{array}{l}-1.863 \\
{[0.939]}\end{array}$ & $\begin{array}{l}8.665 \\
{[0.488]}\end{array}$ & $\begin{array}{l}4.262 \\
{[0.723]}\end{array}$ & $\begin{array}{l}14.060 \\
{[0.578]}\end{array}$ & $\begin{array}{l}10.860 \\
{[0.509]}\end{array}$ & $\begin{array}{l}5.519 \\
{[0.438]}\end{array}$ & $\begin{array}{l}5.763 \\
{[0.464]}\end{array}$ & $\begin{array}{l}8.396 \\
{[0.604]}\end{array}$ \\
\hline BALCH_ey *old_developed ${ }^{3}$ & $\begin{array}{l}19.150^{\star * *} \\
{[0.010]}\end{array}$ & $\begin{array}{l}17.127 \\
{[0.644]}\end{array}$ & $\begin{array}{l}15.909 * \\
{[0.084]}\end{array}$ & $\begin{array}{l}29.628^{* *} \\
{[0.012]}\end{array}$ & $\begin{array}{l}17.475^{\star *} \\
{[0.011]}\end{array}$ & $\begin{array}{l}12.856 \\
{[0.731]}\end{array}$ & $\begin{array}{l}14.183^{*} \\
{[0.099]}\end{array}$ & $\begin{array}{l}27.932^{\star *} \\
{[0.012]}\end{array}$ \\
\hline BALCH_ey * old_less_dev ${ }^{3}$ & $\begin{array}{l}13.701 \\
{[0.467]}\end{array}$ & $\begin{array}{l}-26.348 \\
{[0.134]}\end{array}$ & $\begin{array}{l}-16.216 \\
{[0.299]}\end{array}$ & $\begin{array}{l}10.386 \\
{[0.626]}\end{array}$ & $\begin{array}{l}11.831 \\
{[0.440]}\end{array}$ & $\begin{array}{l}-0.216 \\
{[0.983]}\end{array}$ & $\begin{array}{l}0.979 \\
{[0.925]}\end{array}$ & $\begin{array}{l}18.980 \\
{[0.325]}\end{array}$ \\
\hline BALCH_ey * new_democracy ${ }^{3}$ & $\begin{array}{l}27.075 \\
{[0.107]}\end{array}$ & $\begin{array}{l}-3.142 \\
{[0.734]}\end{array}$ & $\begin{array}{l}1.877 \\
{[0.826]}\end{array}$ & $\begin{array}{l}28.942 \\
{[0.155]}\end{array}$ & $\begin{array}{l}20.381 \\
{[0.159]}\end{array}$ & $\begin{array}{l}-3.496 \\
{[0.633]}\end{array}$ & $\begin{array}{l}-3.170 \\
{[0.653]}\end{array}$ & $\begin{array}{l}22.952 \\
{[0.147]}\end{array}$ \\
\hline GDPPC_gr * old_developed ${ }^{3}$ & $\begin{array}{l}-0.972 \\
{[0.874]}\end{array}$ & $\begin{array}{l}-21.115 \\
{[0.317]}\end{array}$ & $\begin{array}{l}-5.561 \\
{[0.416]}\end{array}$ & $\begin{array}{l}3.861 \\
{[0.601]}\end{array}$ & $\begin{array}{l}0.886 \\
{[0.880]}\end{array}$ & $\begin{array}{l}-17.010 \\
{[0.415]}\end{array}$ & $\begin{array}{l}-2.900 \\
{[0.658]}\end{array}$ & $\begin{array}{l}6.009 \\
{[0.400]}\end{array}$ \\
\hline GDPPC_gr * old_less_dev ${ }^{3}$ & $\begin{array}{l}17.733^{*} \\
{[0.095]}\end{array}$ & $\begin{array}{l}13.402 \\
{[0.152]}\end{array}$ & $\begin{array}{l}13.211 \\
{[0.140]}\end{array}$ & $\begin{array}{l}17.040 \\
{[0.138]}\end{array}$ & $\begin{array}{l}20.764^{\star *} \\
{[0.024]}\end{array}$ & $\begin{array}{l}18.232^{\star \star \star} \\
{[0.008]}\end{array}$ & $\begin{array}{l}18.534^{\star \star \star} \\
{[0.007]}\end{array}$ & $\begin{array}{l}16.846 \\
{[0.108]}\end{array}$ \\
\hline GDPPC_gr * new_democracy ${ }^{3}$ & $\begin{array}{l}26.342^{*} \\
{[0.064]}\end{array}$ & $\begin{array}{l}27.434^{\star \star \star} \\
{[0.001]}\end{array}$ & $\begin{array}{l}27.443^{\star \star \star} \\
{[0.002]}\end{array}$ & $\begin{array}{l}23.114^{\star *} \\
{[0.045]}\end{array}$ & $\begin{array}{l}26.344^{\star *} \\
{[0.017]}\end{array}$ & $\begin{array}{l}19.689 * * * \\
{[0.001]}\end{array}$ & $\begin{array}{l}19.489 * * * \\
{[0.002]}\end{array}$ & $\begin{array}{l}23.702^{* *} \\
{[0.018]}\end{array}$ \\
\hline Developed Countries ${ }^{4}$ & \multicolumn{2}{|c|}{$\begin{array}{c}0.906^{\star \star \star} \\
{[0.001]}\end{array}$} & \multicolumn{2}{|c|}{$\begin{array}{c}0.947^{\star \star \star} \\
{[0.001]}\end{array}$} & \multicolumn{2}{|c|}{$\begin{array}{c}0.802^{\star \star \star} \\
{[0.000]}\end{array}$} & \multicolumn{2}{|c|}{$\begin{array}{c}0.822^{\star \star \star} \\
{[0.000]}\end{array}$} \\
\hline Majoritarian Electoral System ${ }^{4}$ & \multicolumn{2}{|c|}{$\begin{array}{l}0.474^{\star *} \\
{[0.019]}\end{array}$} & \multicolumn{2}{|c|}{$\begin{array}{l}0.440^{\star *} \\
{[0.029]}\end{array}$} & \multicolumn{2}{|c|}{$\begin{array}{c}0.432^{\star * *} \\
{[0.010]}\end{array}$} & \multicolumn{2}{|c|}{$\begin{array}{l}0.398^{\star *} \\
{[0.019]}\end{array}$} \\
\hline Constant & \multicolumn{2}{|c|}{$\begin{array}{c}-0.896^{* * *} \\
{[0.000]}\end{array}$} & \multicolumn{2}{|c|}{$\begin{array}{c}-0.915^{\star * *} \\
{[0.000]}\end{array}$} & \multicolumn{2}{|c|}{$\begin{array}{c}-0.937^{* * *} \\
{[0.000]}\end{array}$} & \multicolumn{2}{|c|}{$\begin{array}{c}-0.947^{\star * *} \\
{[0.000]}\end{array}$} \\
\hline Pseudo $\mathrm{R}^{2}$ & \multicolumn{2}{|c|}{0.124} & \multicolumn{2}{|c|}{0.117} & \multicolumn{2}{|c|}{0.124} & \multicolumn{2}{|c|}{0.117} \\
\hline Akaike's criteria & \multicolumn{2}{|c|}{351.69} & \multicolumn{2}{|c|}{354.03} & \multicolumn{2}{|c|}{465.41} & \multicolumn{2}{|c|}{460.74} \\
\hline Schwartz's criteria & \multicolumn{2}{|c|}{426.06} & \multicolumn{2}{|c|}{428.40} & \multicolumn{2}{|c|}{546.25} & \multicolumn{2}{|c|}{541.57} \\
\hline Observations & \multicolumn{2}{|c|}{255} & \multicolumn{2}{|c|}{255} & \multicolumn{2}{|c|}{347} & \multicolumn{2}{|c|}{347} \\
\hline
\end{tabular}

${ }^{1}$ For variables definitions see Appendix I. The figures in the table are probit coefficients and the figures in the parantheses are P-values. An asterisk (*) indicates multiplication by the binary variable that follows. new_democracy - A binary variable with a value of 1 for new democracies, old_developed - A binary variable with a value of 1 for old and developed democracies, old_less_dev - A binary variable with a value of 1 for old and less developed democracies.

${ }^{2}$ The coefficients in each column are for the interaction of the variable on the top of column with the variable on the left column.

${ }^{3}$ BALCH term - The change in the ratio of the government deficit to GDP in the two years preceding the election year, relative to the two previous years. BALCH ey -The change in the government deficit ratio to GDP In the election year, compared to the previous year. GDPPC_gr - The average growth rate of real per-capita GDP during the leader's current term

${ }^{4}$ The binary variables on the left column have no interaction with other variables.

* - Significant at the 10 percent level; ** - Significant at the 5 percent level; *** - Significant at the 1 percent level. 
Table 15: Additional Effects of the Political Strength of the Leader on the Probability of Reelection ${ }^{1}$

\begin{tabular}{|c|c|c|c|c|c|c|c|c|}
\hline \multirow{2}{*}{ Dependent variable: REELECT } & \multicolumn{4}{|c|}{ Narrow Sample } & \multicolumn{4}{|c|}{ Expanded Sample } \\
\hline & (1) & (2) & (3) & (4) & (5) & (6) & (7) & (8) \\
\hline BALCH_term * developed ${ }^{2}$ & $\begin{array}{l}12.132^{\star \star} \\
{[0.018]}\end{array}$ & $\begin{array}{l}11.262^{\star \star} \\
{[0.029]}\end{array}$ & $\begin{array}{l}11.267^{\star \star} \\
{[0.029]}\end{array}$ & $\begin{array}{l}11.440 \star \star \\
{[0.027]}\end{array}$ & $\begin{array}{l}7.574^{*} \\
{[0.091]}\end{array}$ & $\begin{array}{l}6.611 \\
{[0.140]}\end{array}$ & $\begin{array}{l}6.640 \\
{[0.139]}\end{array}$ & $\begin{array}{l}6.856 \\
{[0.128]}\end{array}$ \\
\hline BALCH_term * less_developed ${ }^{2}$ & $\begin{array}{l}11.381 \\
{[0.139]}\end{array}$ & $\begin{array}{l}6.872 \\
{[0.391]}\end{array}$ & $\begin{array}{l}7.141 \\
{[0.372]}\end{array}$ & $\begin{array}{l}5.601 \\
{[0.493]}\end{array}$ & $\begin{array}{l}8.953^{*} \\
{[0.066]}\end{array}$ & $\begin{array}{l}8.193^{*} \\
{[0.099]}\end{array}$ & $\begin{array}{l}8.484^{\star} \\
{[0.089]}\end{array}$ & $\begin{array}{l}7.913 \\
{[0.111]}\end{array}$ \\
\hline BALCH_ey * developed ${ }^{2}$ & $\begin{array}{l}24.484^{\star * \star} \\
{[0.000]}\end{array}$ & $\begin{array}{l}25.281^{\star \star \star} \\
{[0.000]}\end{array}$ & $\begin{array}{l}25.259^{\star \star \star} \\
{[0.000]}\end{array}$ & $\begin{array}{l}24.542^{\star \star \star} \\
{[0.001]}\end{array}$ & $\begin{array}{l}20.842^{\star * \star} \\
{[0.001]}\end{array}$ & $\begin{array}{l}21.200^{\star \star \star} \\
{[0.001]}\end{array}$ & $\begin{array}{l}21.143^{\star \star \star} \\
{[0.001]}\end{array}$ & $\begin{array}{l}21.051^{\star \star \star} \\
{[0.002]}\end{array}$ \\
\hline BALCH_ey * less_developed ${ }^{2}$ & $\begin{array}{l}-1.860 \\
{[0.820]}\end{array}$ & $\begin{array}{l}-0.613 \\
{[0.944]}\end{array}$ & $\begin{array}{l}-0.411 \\
{[0.962]}\end{array}$ & $\begin{array}{l}0.530 \\
{[0.952]}\end{array}$ & $\begin{array}{l}1.122 \\
{[0.850]}\end{array}$ & $\begin{array}{l}2.792 \\
{[0.654]}\end{array}$ & $\begin{array}{l}3.455 \\
{[0.583]}\end{array}$ & $\begin{array}{l}3.403 \\
{[0.587]}\end{array}$ \\
\hline GDPPC_gr * developed ${ }^{2}$ & $\begin{array}{l}-3.518 \\
{[0.564]}\end{array}$ & $\begin{array}{l}-3.455 \\
{[0.580]}\end{array}$ & $\begin{array}{l}-3.435 \\
{[0.582]}\end{array}$ & $\begin{array}{l}-1.683 \\
{[0.790]}\end{array}$ & $\begin{array}{l}-0.236 \\
{[0.968]}\end{array}$ & $\begin{array}{l}0.596 \\
{[0.921]}\end{array}$ & $\begin{array}{l}0.593 \\
{[0.921]}\end{array}$ & $\begin{array}{l}1.985 \\
{[0.743]}\end{array}$ \\
\hline GDPPC_gr * less_developed ${ }^{2}$ & $\begin{array}{l}18.716^{\star \star} \\
{[0.010]}\end{array}$ & $\begin{array}{l}21.036^{* \star *} \\
{[0.008]}\end{array}$ & $\begin{array}{l}21.121^{\star * *} \\
{[0.008]}\end{array}$ & $\begin{array}{l}22.715^{\star \star \star} \\
{[0.005]}\end{array}$ & $\begin{array}{l}19.370^{\star \star *} \\
{[0.000]}\end{array}$ & $\begin{array}{l}19.525^{\star \star \star} \\
{[0.000]}\end{array}$ & $\begin{array}{l}19.559^{* * *} \\
{[0.001]}\end{array}$ & $\begin{array}{l}20.222^{\star * *} \\
{[0.000]}\end{array}$ \\
\hline PARTY $^{3}$ & & $\begin{array}{l}2.062^{\star \star \star} \\
{[0.001]}\end{array}$ & $\begin{array}{l}2.062^{\star * *} \\
{[0.001]}\end{array}$ & & & $\begin{array}{l}1.887^{\star \star *} \\
{[0.000]}\end{array}$ & $\begin{array}{l}1.823^{\star \star \star} \\
{[0.000]}\end{array}$ & \\
\hline PARTY * majoritarian $^{3}$ & & & & $\begin{array}{l}2.337^{\star \star \star} \\
{[0.000]}\end{array}$ & & & & $\begin{array}{l}2.091^{\star \star \star} \\
{[0.000]}\end{array}$ \\
\hline PARTY * $^{\text {proportional }}{ }^{3}$ & & & & $\begin{array}{l}1.265^{\star} \\
{[0.087]}\end{array}$ & & & & $\begin{array}{l}1.344^{\star *} \\
{[0.019]}\end{array}$ \\
\hline VOTES $^{4}$ & & $\begin{array}{l}1.583^{\star *} \\
{[0.035]}\end{array}$ & & $\begin{array}{l}1.362^{\star} \\
{[0.073]}\end{array}$ & & $\begin{array}{l}1.477^{\star \star \star} \\
{[0.004]}\end{array}$ & & $\begin{array}{l}1.368^{\star \star \star} \\
{[0.008]}\end{array}$ \\
\hline VOTES_R2 ${ }^{5}$ & & & $\begin{array}{l}1.621^{\star \star} \\
{[0.039]}\end{array}$ & & & & $\begin{array}{l}1.476^{\star \star \star} \\
{[0.005]}\end{array}$ & \\
\hline D_R2 ${ }^{6}$ & & & $\begin{array}{l}-0.341 \\
{[0.521]}\end{array}$ & & & & $\begin{array}{l}-0.562 \\
{[0.140]}\end{array}$ & \\
\hline Developed Countries & $\begin{array}{l}1.045^{\star \star \star} \\
{[0.003]}\end{array}$ & $\begin{array}{l}1.150 \text { *** } \\
{[0.002]}\end{array}$ & $\begin{array}{l}1.148^{\star \star \star} \\
{[0.003]}\end{array}$ & $\begin{array}{l}1.349 * \star \star \\
{[0.001]}\end{array}$ & $\begin{array}{l}0.920^{\star * \star} \\
{[0.001]}\end{array}$ & $\begin{array}{l}0.863^{\star \star \star} \\
{[0.003]}\end{array}$ & $\begin{array}{l}0.835^{\star * *} \\
{[0.005]}\end{array}$ & $\begin{array}{l}0.976^{\star \star \star} \\
{[0.001]}\end{array}$ \\
\hline New Democracies & $\begin{array}{l}0.291 \\
{[0.251]}\end{array}$ & $\begin{array}{l}0.393 \\
{[0.147]}\end{array}$ & $\begin{array}{l}0.391 \\
{[0.150]}\end{array}$ & $\begin{array}{l}0.453^{\star} \\
{[0.099]}\end{array}$ & $\begin{array}{l}0.099 \\
{[0.618]}\end{array}$ & $\begin{array}{l}0.198 \\
{[0.346]}\end{array}$ & $\begin{array}{l}0.193 \\
{[0.358]}\end{array}$ & $\begin{array}{l}0.227 \\
{[0.282]}\end{array}$ \\
\hline Constant & $\begin{array}{l}-0.873^{\star \star \star} \\
{[0.003]}\end{array}$ & $\begin{array}{l}-1.835^{\star * \star} \\
{[0.000]}\end{array}$ & $\begin{array}{l}-1.834^{\star \star \star} \\
{[0.000]}\end{array}$ & $\begin{array}{l}-1.840^{\star \star \star} \\
{[0.000]}\end{array}$ & $\begin{array}{l}-0.926^{\star \star \star} \\
{[0.000]}\end{array}$ & $\begin{array}{l}-1.678^{\star \star \star} \\
{[0.000]}\end{array}$ & $\begin{array}{l}-1.625^{\star \star \star} \\
{[0.000]}\end{array}$ & $\begin{array}{l}-1.670^{\star * *} \\
{[0.000]}\end{array}$ \\
\hline Pseudo $\mathrm{R}^{2}$ & 0.083 & 0.119 & 0.119 & 0.132 & 0.083 & 0.119 & 0.119 & 0.132 \\
\hline Akaike's criteria & 320.55 & 312.49 & 314.68 & 310.24 & 428.15 & 414.15 & 415.86 & 413.46 \\
\hline Schwartz's criteria & 351.81 & 350.68 & 356.35 & 351.91 & 462.34 & 455.94 & 461.45 & 459.05 \\
\hline Observations & 238 & 238 & 238 & 238 & 330 & 330 & 330 & 330 \\
\hline
\end{tabular}

${ }^{1}$ For variables definitions see Appendix I. The figures in the table are probit coefficients and the figures in the parantheses are P-values. An asterisk $\left({ }^{\star}\right)$ indicates multiplication by the binary variable that follows.developed - A binary variable with a value of 1 for developed countries,less_developed - A binary variable with a value of 1 for less developed countries.

${ }^{2}$ BALCH_term - The change in the ratio of the government deficit to GDP in the two years preceding the election year, relative to the two previous yearsBALCH_ey -The change in the government deficit ratio to GDP In the election year, compared to the previous year.GDPPC_gr - The average growth rate of real per-capita GDP during the leader's current term.

${ }^{3}$ PARTY - The percent of seats in the parliament held by the leader's party, receives the value 0 in a presidential system.

${ }^{4}$ VOTES - The percent of the votes received by a leader in a presidential system in the first round of the previous elections.

${ }^{5}$ VOTES_R2 - The percent of the votes received by a leader in a presidential system in the last round of the previous elections.

${ }^{6}$ D_R2 - A binary variable receiving the value 1 for a leader in a presidential system, that had to run in more then one round in the previous elections.

* - Significant at the 10 percent level; ** - Significant at the 5 percent level; *** - Significant at the 1 percent level. 
Table 16: Additional Effects of the Inflation Rate on the Probability of Reelection ${ }^{1}$

\begin{tabular}{|c|c|c|c|c|c|c|c|c|}
\hline \multirow{2}{*}{ Dependent variable: REELECT } & \multicolumn{4}{|c|}{ Narrow Sample } & \multicolumn{4}{|c|}{ Expanded Sample } \\
\hline & (1) & (2) & (3) & (4) & (5) & (6) & (7) & (8) \\
\hline BALCH_term * developed ${ }^{2}$ & $\begin{array}{l}12.026^{\star *} \\
{[0.021]}\end{array}$ & $\begin{array}{l}9.889^{\star} \\
{[0.065]}\end{array}$ & $\begin{array}{l}12.070^{\star \star} \\
{[0.021]}\end{array}$ & $\begin{array}{l}11.666^{\star *} \\
{[0.028]}\end{array}$ & $\begin{array}{l}7.529^{\star} \\
{[0.098]}\end{array}$ & $\begin{array}{l}5.883 \\
{[0.207]}\end{array}$ & $\begin{array}{l}7.260 \\
{[0.112]}\end{array}$ & $\begin{array}{l}6.991 \\
{[0.129]}\end{array}$ \\
\hline BALCH_term * less_developed ${ }^{2}$ & $\begin{array}{l}11.166 \\
{[0.142]}\end{array}$ & $\begin{array}{l}5.482 \\
{[0.501]}\end{array}$ & $\begin{array}{l}5.791 \\
{[0.476]}\end{array}$ & $\begin{array}{l}5.779 \\
{[0.479]}\end{array}$ & $\begin{array}{l}9.147^{\star} \\
{[0.060]}\end{array}$ & $\begin{array}{l}8.071 \\
{[0.106]}\end{array}$ & $\begin{array}{l}8.317 \\
{[0.104]}\end{array}$ & $\begin{array}{l}8.543^{*} \\
{[0.096]}\end{array}$ \\
\hline BALCH_ey * developed ${ }^{2}$ & $\begin{array}{l}20.575^{\star \star \star} \\
{[0.004]}\end{array}$ & $\begin{array}{l}17.131^{\star \star} \\
{[0.027]}\end{array}$ & $\begin{array}{l}24.374^{\star \star \star} \\
{[0.001]}\end{array}$ & $\begin{array}{l}21.562^{\star \star \star} \\
{[0.004]}\end{array}$ & $\begin{array}{l}17.714^{* \star *} \\
{[0.008]}\end{array}$ & $\begin{array}{l}15.097^{\star *} \\
{[0.034]}\end{array}$ & $\begin{array}{l}20.594^{\star * \star} \\
{[0.002]}\end{array}$ & $\begin{array}{l}18.424^{\star * *} \\
{[0.007]}\end{array}$ \\
\hline BALCH_ey * less_developed ${ }^{2}$ & $\begin{array}{l}-3.606 \\
{[0.598]}\end{array}$ & $\begin{array}{l}1.660 \\
{[0.853]}\end{array}$ & $\begin{array}{l}0.825 \\
{[0.926]}\end{array}$ & $\begin{array}{l}1.456 \\
{[0.870]}\end{array}$ & $\begin{array}{l}-0.590 \\
{[0.911]}\end{array}$ & $\begin{array}{l}4.171 \\
{[0.512]}\end{array}$ & $\begin{array}{l}3.717 \\
{[0.556]}\end{array}$ & $\begin{array}{l}3.830 \\
{[0.546]}\end{array}$ \\
\hline GDPPC_gr * developed ${ }^{2}$ & $\begin{array}{l}0.714 \\
{[0.916]}\end{array}$ & $\begin{array}{l}3.292 \\
{[0.634]}\end{array}$ & $\begin{array}{l}3.119 \\
{[0.651]}\end{array}$ & $\begin{array}{l}2.790 \\
{[0.688]}\end{array}$ & $\begin{array}{l}4.462 \\
{[0.489]}\end{array}$ & $\begin{array}{l}7.136 \\
{[0.278]}\end{array}$ & $\begin{array}{l}7.230 \\
{[0.272]}\end{array}$ & $\begin{array}{l}6.873 \\
{[0.298]}\end{array}$ \\
\hline GDPPC_gr * less_developed ${ }^{2}$ & $\begin{array}{l}22.999^{\star \star \star} \\
{[0.001]}\end{array}$ & $\begin{array}{l}23.973^{\star \star \star} \\
{[0.004]}\end{array}$ & $\begin{array}{l}21.754^{\star * *} \\
{[0.007]}\end{array}$ & $\begin{array}{l}22.536^{\star \star \star} \\
{[0.006]}\end{array}$ & $\begin{array}{l}21.125^{\star \star \star} \\
{[0.000]}\end{array}$ & $\begin{array}{l}19.563^{\star \star \star} \\
{[0.001]}\end{array}$ & $\begin{array}{l}19.774^{* * *} \\
{[0.001]}\end{array}$ & $\begin{array}{l}19.485^{\star \star \star} \\
{[0.001]}\end{array}$ \\
\hline INF_ey * Developed ${ }^{3}$ & & $\begin{array}{l}-7.085^{\star \star \star} \\
{[0.005]}\end{array}$ & & & & $\begin{array}{l}-5.889^{* *} \\
{[0.012]}\end{array}$ & & \\
\hline INF_ey * Less_Developed ${ }^{3}$ & & $\begin{array}{l}0.844 \\
{[0.547]}\end{array}$ & & & & $\begin{array}{l}-0.188 \\
{[0.835]}\end{array}$ & & \\
\hline INFCH_ey * Developed ${ }^{4}$ & $\begin{array}{l}-7.804^{*} \\
{[0.059]}\end{array}$ & $\begin{array}{l}-6.221 \\
{[0.129]}\end{array}$ & $\begin{array}{l}-6.831^{*} \\
{[0.067]}\end{array}$ & $\begin{array}{l}-9.606^{\star *} \\
{[0.031]}\end{array}$ & $\begin{array}{l}-8.148^{\star \star} \\
{[0.043]}\end{array}$ & $\begin{array}{l}-7.027^{*} \\
{[0.075]}\end{array}$ & $\begin{array}{l}-7.546^{\star \star} \\
{[0.040]}\end{array}$ & $\begin{array}{l}-9.949^{\star *} \\
{[0.021]}\end{array}$ \\
\hline INFCH_ey * Less_Developed ${ }^{4}$ & $\begin{array}{l}3.471 \\
{[0.231]}\end{array}$ & & $\begin{array}{l}1.880 \\
{[0.519]}\end{array}$ & $\begin{array}{l}2.177 \\
{[0.462]}\end{array}$ & $\begin{array}{l}0.587 \\
{[0.542]}\end{array}$ & & $\begin{array}{l}0.193 \\
{[0.832]}\end{array}$ & $\begin{array}{l}0.352 \\
{[0.713]}\end{array}$ \\
\hline Average_INF * Developed $^{5}$ & $\begin{array}{l}-2.100^{*} \\
{[0.068]}\end{array}$ & & & $\begin{array}{l}-2.406^{\star \star} \\
{[0.045]}\end{array}$ & $\begin{array}{l}-1.566 \\
{[0.159]}\end{array}$ & & & $\begin{array}{l}-1.950^{*} \\
{[0.090]}\end{array}$ \\
\hline Average_INF * Less_Developed ${ }^{5}$ & $\begin{array}{l}-0.301 \\
{[0.678]}\end{array}$ & & & $\begin{array}{l}0.213 \\
{[0.783]}\end{array}$ & $\begin{array}{l}-0.582 \\
{[0.316]}\end{array}$ & & & $\begin{array}{l}-0.355 \\
{[0.560]}\end{array}$ \\
\hline PARTY $^{6}$ & & $\begin{array}{l}2.146^{\star \star *} \\
{[0.002]}\end{array}$ & $\begin{array}{l}1.803^{\star * *} \\
{[0.006]}\end{array}$ & $\begin{array}{l}1.998^{\star * *} \\
{[0.003]}\end{array}$ & & $\begin{array}{l}1.855^{\star \star \star} \\
{[0.000]}\end{array}$ & $\begin{array}{l}1.716^{\star * *} \\
{[0.000]}\end{array}$ & $\begin{array}{l}1.795^{\star \star \star} \\
{[0.000]}\end{array}$ \\
\hline VOTES $^{7}$ & & $\begin{array}{l}1.609 * * \\
{[0.039]}\end{array}$ & $\begin{array}{l}1.414^{\star} \\
{[0.064]}\end{array}$ & $\begin{array}{l}1.453^{\star} \\
{[0.059]}\end{array}$ & & $\begin{array}{l}1.490^{\star \star \star} \\
{[0.004]}\end{array}$ & $\begin{array}{l}1.414^{\star \star \star} \\
{[0.007]}\end{array}$ & $\begin{array}{l}1.465^{\star \star \star} \\
{[0.005]}\end{array}$ \\
\hline Developed Countries & $\begin{array}{l}1.364^{\star \star *} \\
{[0.000]}\end{array}$ & $\begin{array}{l}1.757^{\star \star *} \\
{[0.000]}\end{array}$ & $\begin{array}{l}1.048^{\star \star \star} \\
{[0.008]}\end{array}$ & $\begin{array}{l}1.353^{\star \star \star} \\
{[0.002]}\end{array}$ & $\begin{array}{l}0.969^{* \star *} \\
{[0.002]}\end{array}$ & $\begin{array}{l}1.092^{\star \star \star} \\
{[0.004]}\end{array}$ & $\begin{array}{l}0.716^{\star *} \\
{[0.020]}\end{array}$ & $\begin{array}{l}0.836^{\star *} \\
{[0.014]}\end{array}$ \\
\hline New Democracies & $\begin{array}{l}0.725^{\star * *} \\
{[0.006]}\end{array}$ & $\begin{array}{l}0.648^{\star \star} \\
{[0.028]}\end{array}$ & $\begin{array}{l}0.444 \\
{[0.113]}\end{array}$ & $\begin{array}{l}0.627^{\star *} \\
{[0.039]}\end{array}$ & $\begin{array}{l}0.369^{*} \\
{[0.065]}\end{array}$ & $\begin{array}{l}0.315 \\
{[0.153]}\end{array}$ & $\begin{array}{l}0.199 \\
{[0.351]}\end{array}$ & $\begin{array}{l}0.310 \\
{[0.166]}\end{array}$ \\
\hline Majoritarian Electoral System & $\begin{array}{l}0.499^{\star \star} \\
{[0.015]}\end{array}$ & $\begin{array}{l}0.485^{\star *} \\
{[0.032]}\end{array}$ & $\begin{array}{l}0.420^{\star} \\
{[0.056]}\end{array}$ & $\begin{array}{l}0.435^{\star} \\
{[0.053]}\end{array}$ & $\begin{array}{l}0.413^{\star \star} \\
{[0.016]}\end{array}$ & $\begin{array}{l}0.317^{\star} \\
{[0.095]}\end{array}$ & $\begin{array}{l}0.314^{\star} \\
{[0.091]}\end{array}$ & $\begin{array}{l}0.291 \\
{[0.125]}\end{array}$ \\
\hline Constant & $\begin{array}{l}-1.279^{\star \star *} \\
{[0.000]}\end{array}$ & $\begin{array}{l}-2.340^{* \star \star} \\
{[0.000]}\end{array}$ & $\begin{array}{l}-1.895^{\star \star \star} \\
{[0.000]}\end{array}$ & $\begin{array}{l}-2.111^{\star * *} \\
{[0.000]}\end{array}$ & $\begin{array}{l}-1.096^{\star \star \star} \\
{[0.000]}\end{array}$ & $\begin{array}{l}-1.798^{\star * \star} \\
{[0.000]}\end{array}$ & $\begin{array}{l}-1.716^{\star \star \star} \\
{[0.000]}\end{array}$ & $\begin{array}{l}-1.725^{\star \star *} \\
{[0.000]}\end{array}$ \\
\hline Pseudo $\mathrm{R}^{2}$ & 0.132 & 0.167 & 0.142 & 0.156 & 0.116 & 0.157 & 0.142 & 0.149 \\
\hline Akaike's criteria & 334.90 & 304.94 & 310.95 & 310.55 & 446.54 & 408.26 & 412.85 & 413.54 \\
\hline Schwartz's criteria & 384.48 & 357.02 & 359.57 & 366.11 & 500.43 & 465.25 & 466.04 & 474.33 \\
\hline Observations & 255 & 238 & 238 & 238 & 347 & 330 & 330 & 330 \\
\hline
\end{tabular}

${ }^{1}$ For variables definitions see Appendix I. The figures in the table are probit coefficients and the figures in the parantheses are P-values. An asterisk (*) indicates multiplication by the binary variable that follows.developed - A binary variable with a value of 1 for developed countries,less_developed - A binary variable with a value of 1 for less developed countries.

${ }^{2}$ BALCH_term - The change in the ratio of the government deficit to GDP in the two years preceding the election year, relative to the two previous yearsBALCH_ey -The change in the government deficit ratio to GDP In the election year, compared to the previous year.GDPPC_gr - The average growth rate of real per-capita GDP during the leader's current term.

${ }^{3}$ INF_ey - The inflation rate in the election year.

${ }^{4}$ INFCH_ey - The increase in the inflation rate from the year preceding the election year to the election year.

${ }^{5}$ Average_INF - The average rate of inflation rate during the leader's current term.

${ }^{6}$ PARTY - The percent of seats in the parliament held by the leader's party, receives the value 0 in a presidential system.

${ }^{7}$ VOTES - The percent of the votes received by a leader in a presidential system in the first round of the previous elections.

* - Significant at the 10 percent level; ** - Significant at the 5 percent level; ** - Significant at the 1 percent level. 
Table 17: Separate Effects of Global and Domestic Induced Growth on the Probability of Reelection ${ }^{1}$

\begin{tabular}{|c|c|c|c|c|c|c|c|c|}
\hline \multirow{2}{*}{ Dependent variable: REELECT } & \multicolumn{4}{|c|}{ Narrow Sample } & \multicolumn{4}{|c|}{ Expanded Sample } \\
\hline & $(1)$ & $(2)$ & (3) & (4) & $(5)$ & (6) & (7) & (8) \\
\hline BALCH_term * developed ${ }^{2}$ & $\begin{array}{l}11.913^{\star \star} \\
{[0.023]}\end{array}$ & $\begin{array}{l}9.670^{*} \\
{[0.073]}\end{array}$ & $\begin{array}{l}11.812^{\star \star} \\
{[0.025]}\end{array}$ & $\begin{array}{l}11.478^{\star \star} \\
{[0.031]}\end{array}$ & $\begin{array}{l}7.432 \\
{[0.103]}\end{array}$ & $\begin{array}{l}5.766 \\
{[0.217]}\end{array}$ & $\begin{array}{l}7.110 \\
{[0.121]}\end{array}$ & $\begin{array}{l}6.876 \\
{[0.137]}\end{array}$ \\
\hline BALCH_term * less_developed ${ }^{2}$ & $\begin{array}{l}10.848 \\
{[0.151]}\end{array}$ & $\begin{array}{l}5.119 \\
{[0.529]}\end{array}$ & $\begin{array}{l}5.465 \\
{[0.502]}\end{array}$ & $\begin{array}{l}5.752 \\
{[0.479]}\end{array}$ & $\begin{array}{l}8.726^{*} \\
{[0.072]}\end{array}$ & $\begin{array}{l}8.458^{\star} \\
{[0.092]}\end{array}$ & $\begin{array}{l}8.659^{*} \\
{[0.092]}\end{array}$ & $\begin{array}{l}8.689^{*} \\
{[0.090]}\end{array}$ \\
\hline BALCH_ey * developed ${ }^{2}$ & $\begin{array}{l}20.280^{\star * \star} \\
{[0.005]}\end{array}$ & $\begin{array}{l}16.535^{\star \star} \\
{[0.033]}\end{array}$ & $\begin{array}{l}23.577^{\star \star \star} \\
{[0.001]}\end{array}$ & $\begin{array}{l}20.995^{\star \star \star} \\
{[0.005]}\end{array}$ & $\begin{array}{l}17.387^{\star \star \star} \\
{[0.009]}\end{array}$ & $\begin{array}{l}14.696^{\star \star} \\
{[0.039]}\end{array}$ & $\begin{array}{l}19.981^{\star \star \star} \\
{[0.003]}\end{array}$ & $\begin{array}{l}17.998^{\star \star \star} \\
{[0.009]}\end{array}$ \\
\hline BALCH_ey * less_developed ${ }^{2}$ & $\begin{array}{l}-2.731 \\
{[0.701]}\end{array}$ & $\begin{array}{l}0.977 \\
{[0.914]}\end{array}$ & $\begin{array}{l}0.203 \\
{[0.982]}\end{array}$ & $\begin{array}{l}0.645 \\
{[0.943]}\end{array}$ & $\begin{array}{l}-0.803 \\
{[0.881]}\end{array}$ & $\begin{array}{l}3.762 \\
{[0.556]}\end{array}$ & $\begin{array}{l}3.341 \\
{[0.599]}\end{array}$ & $\begin{array}{l}3.409 \\
{[0.592]}\end{array}$ \\
\hline GLOBAL_gr * Developed $^{3}$ & $\begin{array}{l}6.604 \\
{[0.703]}\end{array}$ & $\begin{array}{l}15.470 \\
{[0.391]}\end{array}$ & $\begin{array}{l}16.369 \\
{[0.356]}\end{array}$ & $\begin{array}{l}13.760 \\
{[0.442]}\end{array}$ & $\begin{array}{l}13.148 \\
{[0.441]}\end{array}$ & $\begin{array}{l}18.983 \\
{[0.281]}\end{array}$ & $\begin{array}{l}20.890 \\
{[0.230]}\end{array}$ & $\begin{array}{l}18.744 \\
{[0.285]}\end{array}$ \\
\hline GLOBAL_gr * Less_Developed ${ }^{3}$ & $\begin{array}{l}29.389 \\
{[0.654]}\end{array}$ & $\begin{array}{l}-31.595 \\
{[0.684]}\end{array}$ & $\begin{array}{l}-26.583 \\
{[0.733]}\end{array}$ & $\begin{array}{l}-25.313 \\
{[0.746]}\end{array}$ & $\begin{array}{l}0.143 \\
{[0.995]}\end{array}$ & $\begin{array}{l}-18.249 \\
{[0.476]}\end{array}$ & $\begin{array}{l}-17.147 \\
{[0.501]}\end{array}$ & $\begin{array}{l}-17.299 \\
{[0.498]}\end{array}$ \\
\hline DOMESTIC_gr * developed ${ }^{3}$ & $\begin{array}{l}0.059 \\
{[0.993]}\end{array}$ & $\begin{array}{l}2.084 \\
{[0.772]}\end{array}$ & $\begin{array}{l}1.700 \\
{[0.813]}\end{array}$ & $\begin{array}{l}1.544 \\
{[0.831]}\end{array}$ & $\begin{array}{l}3.771 \\
{[0.573]}\end{array}$ & $\begin{array}{l}6.059 \\
{[0.374]}\end{array}$ & $\begin{array}{l}5.900 \\
{[0.388]}\end{array}$ & $\begin{array}{l}5.889 \\
{[0.390]}\end{array}$ \\
\hline DOMESTIC_gr * less_developed ${ }^{3}$ & $\begin{array}{l}23.008^{\star \star \star} \\
{[0.001]}\end{array}$ & $\begin{array}{l}24.662^{\star \star \star} \\
{[0.003]}\end{array}$ & $\begin{array}{l}22.314^{\star * \star} \\
{[0.006]}\end{array}$ & $\begin{array}{l}22.899^{\star \star \star} \\
{[0.005]}\end{array}$ & $\begin{array}{l}21.909^{\star \star \star} \\
{[0.000]}\end{array}$ & $\begin{array}{l}20.525^{\star \star \star} \\
{[0.001]}\end{array}$ & $\begin{array}{l}20.699 \star \star \star \\
{[0.000]}\end{array}$ & $\begin{array}{l}20.929 * \star \star \\
{[0.000]}\end{array}$ \\
\hline INF_ey * Developed ${ }^{4}$ & & $\begin{array}{l}-7.043^{\star * \star} \\
{[0.006]}\end{array}$ & & & & $\begin{array}{l}-5.830^{\star *} \\
{[0.013]}\end{array}$ & & \\
\hline INF_ey * Less_Developed ${ }^{4}$ & & $\begin{array}{l}0.883 \\
{[0.530]}\end{array}$ & & & & $\begin{array}{l}-0.211 \\
{[0.816]}\end{array}$ & & \\
\hline INFCH_ey * Developed ${ }^{5}$ & $\begin{array}{l}-7.702^{\star} \\
{[0.062]}\end{array}$ & $\begin{array}{l}-6.305 \\
{[0.124]}\end{array}$ & $\begin{array}{l}-6.808^{*} \\
{[0.068]}\end{array}$ & $\begin{array}{l}-9.517^{\star *} \\
{[0.032]}\end{array}$ & $\begin{array}{l}-8.119^{\star *} \\
{[0.043]}\end{array}$ & $\begin{array}{l}-7.117^{*} \\
{[0.071]}\end{array}$ & $\begin{array}{l}-7.554^{\star *} \\
{[0.040]}\end{array}$ & $\begin{array}{l}-10.003^{\star \star} \\
{[0.021]}\end{array}$ \\
\hline INFCH_ey * Less_Developed ${ }^{5}$ & $\begin{array}{l}3.654 \\
{[0.204]}\end{array}$ & & $\begin{array}{l}1.853 \\
{[0.529]}\end{array}$ & $\begin{array}{l}2.039 \\
{[0.491]}\end{array}$ & $\begin{array}{l}0.396 \\
{[0.662]}\end{array}$ & & $\begin{array}{l}0.179 \\
{[0.845]}\end{array}$ & $\begin{array}{l}0.197 \\
{[0.829]}\end{array}$ \\
\hline Average_INF * Developed $^{6}$ & $\begin{array}{l}-2.049^{*} \\
{[0.075]}\end{array}$ & & & $\begin{array}{l}-2.368^{\star *} \\
{[0.049]}\end{array}$ & $\begin{array}{l}-1.492 \\
{[0.181]}\end{array}$ & & & $\begin{array}{l}-1.884 \\
{[0.104]}\end{array}$ \\
\hline PARTY $^{7}$ & & $\begin{array}{l}2.242^{\star \star \star} \\
{[0.001]}\end{array}$ & $\begin{array}{l}1.895^{\star \star \star} \\
{[0.004]}\end{array}$ & $\begin{array}{l}2.049 * \star \star \\
{[0.003]}\end{array}$ & & $\begin{array}{l}1.890^{\star \star *} \\
{[0.000]}\end{array}$ & $\begin{array}{l}1.756^{\star \star \star} \\
{[0.000]}\end{array}$ & $\begin{array}{l}1.843^{\star \star \star} \\
{[0.000]}\end{array}$ \\
\hline VOTES $^{8}$ & & $\begin{array}{l}1.699^{\star *} \\
{[0.034]}\end{array}$ & $\begin{array}{l}1.509^{\star} \\
{[0.053]}\end{array}$ & $\begin{array}{l}1.534^{*} \\
{[0.051]}\end{array}$ & & $\begin{array}{l}1.497^{\star \star \star} \\
{[0.005]}\end{array}$ & $\begin{array}{l}1.431^{\star \star \star} \\
{[0.007]}\end{array}$ & $\begin{array}{l}1.448^{\star \star \star} \\
{[0.006]}\end{array}$ \\
\hline Developed Countries & $\begin{array}{l}1.906 \\
{[0.226]}\end{array}$ & $\begin{array}{l}0.772 \\
{[0.676]}\end{array}$ & $\begin{array}{l}0.146 \\
{[0.937]}\end{array}$ & $\begin{array}{l}0.499 \\
{[0.787]}\end{array}$ & $\begin{array}{l}0.859 \\
{[0.197]}\end{array}$ & $\begin{array}{l}0.430 \\
{[0.575]}\end{array}$ & $\begin{array}{l}0.040 \\
{[0.955]}\end{array}$ & $\begin{array}{l}0.259 \\
{[0.725]}\end{array}$ \\
\hline New Democracies & $\begin{array}{l}0.715^{\star \star \star} \\
{[0.006]}\end{array}$ & $\begin{array}{l}0.660^{\star *} \\
{[0.026]}\end{array}$ & $\begin{array}{l}0.457 \\
{[0.104]}\end{array}$ & $\begin{array}{l}0.645^{\star *} \\
{[0.031]}\end{array}$ & $\begin{array}{l}0.349^{\star} \\
{[0.079]}\end{array}$ & $\begin{array}{l}0.323 \\
{[0.143]}\end{array}$ & $\begin{array}{l}0.210 \\
{[0.327]}\end{array}$ & $\begin{array}{l}0.299 \\
{[0.178]}\end{array}$ \\
\hline Majoritarian Electoral System & $\begin{array}{l}0.509^{\star *} \\
{[0.014]}\end{array}$ & $\begin{array}{l}0.528^{\star *} \\
{[0.025]}\end{array}$ & $\begin{array}{l}0.459^{\star *} \\
{[0.044]}\end{array}$ & $\begin{array}{l}0.460^{\star *} \\
{[0.046]}\end{array}$ & $\begin{array}{l}0.460^{\star \star \star} \\
{[0.008]}\end{array}$ & $\begin{array}{l}0.362^{\star} \\
{[0.064]}\end{array}$ & $\begin{array}{l}0.361^{\star} \\
{[0.060]}\end{array}$ & $\begin{array}{l}0.352^{\star} \\
{[0.068]}\end{array}$ \\
\hline Constant & $\begin{array}{l}-1.978 \\
{[0.183]}\end{array}$ & $\begin{array}{l}-1.724 \\
{[0.331]}\end{array}$ & $\begin{array}{l}-1.382 \\
{[0.431]}\end{array}$ & $\begin{array}{l}-1.571 \\
{[0.374]}\end{array}$ & $\begin{array}{l}-1.222^{\star \star \star} \\
{[0.009]}\end{array}$ & $\begin{array}{l}-1.467^{\star \star} \\
{[0.018]}\end{array}$ & $\begin{array}{l}-1.415^{\star \star} \\
{[0.015]}\end{array}$ & $\begin{array}{l}-1.486^{\star *} \\
{[0.011]}\end{array}$ \\
\hline Pseudo $\mathbf{R}^{2}$ & 0.132 & 0.169 & 0.144 & 0.157 & 0.115 & 0.159 & 0.145 & 0.151 \\
\hline Akaike's criteria & 336.73 & 308.27 & 314.21 & 312.10 & 449.28 & 411.26 & 415.71 & 414.93 \\
\hline Schwartz's criteria & 389.85 & 367.30 & 369.76 & 371.12 & 507.02 & 475.84 & 476.50 & 479.51 \\
\hline Observations & 255 & 238 & 238 & 238 & 347 & 330 & 330 & 330 \\
\hline
\end{tabular}

${ }^{1}$ For variables definitions see Appendix I. The figures in the table are probit coefficients and the figures in the parantheses are P-values. An asterisk $\left({ }^{*}\right)$ indicates multiplication by the binary variable that follows.developed - A binary variable with a value of 1 for developed countries,less_developed - A binary variable with a value of 1 for less developed countries.

${ }^{2}$ BALCH_term - The change in the ratio of the government deficit to GDP in the two years preceding the election year, relative to the two previous yearsBALCH ey -The change in the government deficit ratio to GDP In the election year, compared to the previous year.

${ }^{3}$ GLOBAL_gr - The predicted growth rate of the country during the leeader's term in office based on a regression of the growth rates on the product of global growth and the share of exports in the country's GDP. DOMESTIC_gr - The difference between GDPPC_gr and GLOBAL_gr.

${ }^{4}$ INF_ey - The inflation rate in the election year.

${ }^{5} \mathrm{INFCH}$ ey - The increase in the inflation rate from the year preceding the election year to the election year.

${ }^{6}$ Average_INF - The average rate of inflation rate during the leader's current term.

${ }^{7}$ PARTY - The percent of seats in the parliament held by the leader's party, receives the value 0 in a presidential system.

${ }^{8}$ VOTES - The percent of the votes received by a leader in a presidential system in the first round of the previous elections.

* - Significant at the 10 percent level; ** - Significant at the 5 percent level; *** - Significant at the 1 percent level. 
Table 18: Separate Effects of Revenue and Expenditure on the Probability of Reelection ${ }^{1}$

\begin{tabular}{|c|c|c|c|c|c|c|c|c|}
\hline \multirow{2}{*}{ Dependent variable: REELECT } & \multicolumn{4}{|c|}{ Narrow Sample } & \multicolumn{4}{|c|}{ Expanded Sample } \\
\hline & $(1)$ & $(2)$ & $(3)$ & $(4)$ & $(5)$ & $(6)$ & $(7)$ & $(8)$ \\
\hline REVCH_term * developed ${ }^{2}$ & $\begin{array}{l}11.083^{\star *} \\
{[0.049]}\end{array}$ & $\begin{array}{l}8.894 \\
{[0.127]}\end{array}$ & $\begin{array}{l}11.084^{\star *} \\
{[0.048]}\end{array}$ & $\begin{array}{l}10.738^{*} \\
{[0.060]}\end{array}$ & $\begin{array}{l}6.483 \\
{[0.193]}\end{array}$ & $\begin{array}{l}4.726 \\
{[0.357]}\end{array}$ & $\begin{array}{l}6.182 \\
{[0.213]}\end{array}$ & $\begin{array}{l}5.903 \\
{[0.240]}\end{array}$ \\
\hline REVCH_term * less_developed ${ }^{2}$ & $\begin{array}{l}11.325 \\
{[0.235]}\end{array}$ & $\begin{array}{l}6.919 \\
{[0.488]}\end{array}$ & $\begin{array}{l}6.076 \\
{[0.542]}\end{array}$ & $\begin{array}{l}6.453 \\
{[0.516]}\end{array}$ & $\begin{array}{l}12.815^{\star} \\
{[0.069]}\end{array}$ & $\begin{array}{l}10.272 \\
{[0.156]}\end{array}$ & $\begin{array}{l}10.468 \\
{[0.153]}\end{array}$ & $\begin{array}{l}10.981 \\
{[0.139]}\end{array}$ \\
\hline EXPCH_term * developed ${ }^{2}$ & $\begin{array}{l}-10.809^{* *} \\
{[0.048]}\end{array}$ & $\begin{array}{l}-8.613 \\
{[0.128]}\end{array}$ & $\begin{array}{l}-11.508^{\star *} \\
{[0.034]}\end{array}$ & $\begin{array}{l}-10.966^{\star *} \\
{[0.047]}\end{array}$ & $\begin{array}{l}-6.293 \\
{[0.187]}\end{array}$ & $\begin{array}{l}-4.574 \\
{[0.352]}\end{array}$ & $\begin{array}{l}-6.637 \\
{[0.162]}\end{array}$ & $\begin{array}{l}-6.188 \\
{[0.198]}\end{array}$ \\
\hline EXPCH_term * less_developed ${ }^{2}$ & $\begin{array}{l}-9.865 \\
{[0.211]}\end{array}$ & $\begin{array}{l}-4.942 \\
{[0.551]}\end{array}$ & $\begin{array}{l}-5.239 \\
{[0.529]}\end{array}$ & $\begin{array}{l}-5.086 \\
{[0.544]}\end{array}$ & $\begin{array}{l}-8.883^{\star} \\
{[0.074]}\end{array}$ & $\begin{array}{l}-7.872 \\
{[0.118]}\end{array}$ & $\begin{array}{l}-8.199 \\
{[0.113]}\end{array}$ & $\begin{array}{l}-8.439 \\
{[0.103]}\end{array}$ \\
\hline REVCH_ey * developed ${ }^{2}$ & $\begin{array}{l}33.346^{\star \star \star} \\
{[0.002]}\end{array}$ & $\begin{array}{l}30.668^{\star \star \star} \\
{[0.007]}\end{array}$ & $\begin{array}{l}33.762^{\star \star \star} \\
{[0.002]}\end{array}$ & $\begin{array}{l}32.869^{\star \star \star} \\
{[0.004]}\end{array}$ & $\begin{array}{l}29.863^{\star \star \star} \\
{[0.003]}\end{array}$ & $\begin{array}{l}28.176^{\star \star \star} \\
{[0.007]}\end{array}$ & $\begin{array}{l}29.596^{\star \star \star} \\
{[0.004]}\end{array}$ & $\begin{array}{l}29.076^{\star \star \star} \\
{[0.005]}\end{array}$ \\
\hline REVCH_ey * less_developed ${ }^{2}$ & $\begin{array}{l}5.445 \\
{[0.548]}\end{array}$ & $\begin{array}{l}6.538 \\
{[0.533]}\end{array}$ & $\begin{array}{l}5.925 \\
{[0.571]}\end{array}$ & $\begin{array}{l}7.016 \\
{[0.507]}\end{array}$ & $\begin{array}{l}2.976 \\
{[0.658]}\end{array}$ & $\begin{array}{l}5.891 \\
{[0.437]}\end{array}$ & $\begin{array}{l}5.489 \\
{[0.468]}\end{array}$ & $\begin{array}{l}5.775 \\
{[0.448]}\end{array}$ \\
\hline EXPCH_ey * developed ${ }^{2}$ & $\begin{array}{l}-19.707^{\star \star \star} \\
{[0.008]}\end{array}$ & $\begin{array}{l}-14.926^{*} \\
{[0.069]}\end{array}$ & $\begin{array}{l}-24.200^{\star \star \star} \\
{[0.001]}\end{array}$ & $\begin{array}{l}-20.865^{\star \star \star \star} \\
{[0.006]}\end{array}$ & $\begin{array}{l}-16.570^{\star *} \\
{[0.016]}\end{array}$ & $\begin{array}{l}-12.730^{*} \\
{[0.093]}\end{array}$ & $\begin{array}{l}-20.110^{\star \star \star} \\
{[0.004]}\end{array}$ & $\begin{array}{l}-17.433^{\star *} \\
{[0.014]}\end{array}$ \\
\hline EXPCH_ey * less_developed ${ }^{2}$ & $\begin{array}{l}7.655 \\
{[0.311]}\end{array}$ & $\begin{array}{l}1.053 \\
{[0.913]}\end{array}$ & $\begin{array}{l}2.507 \\
{[0.795]}\end{array}$ & $\begin{array}{l}2.068 \\
{[0.832]}\end{array}$ & $\begin{array}{l}2.636 \\
{[0.652]}\end{array}$ & $\begin{array}{l}-2.993 \\
{[0.673]}\end{array}$ & $\begin{array}{l}-2.425 \\
{[0.731]}\end{array}$ & $\begin{array}{l}-2.438 \\
{[0.731]}\end{array}$ \\
\hline GDPPC_gr * developed ${ }^{2}$ & $\begin{array}{l}-0.034 \\
{[0.996]}\end{array}$ & $\begin{array}{l}2.584 \\
{[0.719]}\end{array}$ & $\begin{array}{l}2.326 \\
{[0.742]}\end{array}$ & $\begin{array}{l}1.990 \\
{[0.781]}\end{array}$ & $\begin{array}{l}3.606 \\
{[0.587]}\end{array}$ & $\begin{array}{l}6.347 \\
{[0.350]}\end{array}$ & $\begin{array}{l}6.463 \\
{[0.337]}\end{array}$ & $\begin{array}{l}6.067 \\
{[0.371]}\end{array}$ \\
\hline GDPPC_gr * less_developed ${ }^{2}$ & $\begin{array}{l}21.591^{\star \star \star} \\
{[0.003]}\end{array}$ & $\begin{array}{l}23.518^{\star \star \star} \\
{[0.005]}\end{array}$ & $\begin{array}{l}20.807^{\star \star} \\
{[0.011]}\end{array}$ & $\begin{array}{l}21.662^{\star \star \star} \\
{[0.009]}\end{array}$ & $\begin{array}{l}21.197^{\star \star \star} \\
{[0.000]}\end{array}$ & $\begin{array}{l}19.625^{\star \star \star} \\
{[0.001]}\end{array}$ & $\begin{array}{l}19.869 \text { *** } \\
{[0.001]}\end{array}$ & $\begin{array}{l}19.577^{\star \star \star} \\
{[0.001]}\end{array}$ \\
\hline INF_ey * Developed ${ }^{3}$ & & $\begin{array}{l}-8.088^{\star \star \star} \\
{[0.002]}\end{array}$ & & & & $\begin{array}{l}-6.906^{\star \star \star} \\
{[0.005]}\end{array}$ & & \\
\hline INF_ey * Less_Developed ${ }^{3}$ & & $\begin{array}{l}0.978 \\
{[0.490]}\end{array}$ & & & & $\begin{array}{l}-0.175 \\
{[0.846]}\end{array}$ & & \\
\hline INFCH_ey * Developed ${ }^{4}$ & $\begin{array}{l}-8.361^{\star \star} \\
{[0.045]}\end{array}$ & $\begin{array}{l}-6.384 \\
{[0.116]}\end{array}$ & $\begin{array}{l}-6.965^{\star} \\
{[0.062]}\end{array}$ & $\begin{array}{l}-10.179^{\star \star} \\
{[0.023]}\end{array}$ & $\begin{array}{l}-8.596^{\star \star} \\
{[0.034]}\end{array}$ & $\begin{array}{l}-7.166^{*} \\
{[0.067]}\end{array}$ & $\begin{array}{l}-7.655^{\star \star} \\
{[0.036]}\end{array}$ & $\begin{array}{l}-10.464^{\star \star} \\
{[0.016]}\end{array}$ \\
\hline INFCH_ey *Less_Developed ${ }^{4}$ & $\begin{array}{l}4.445 \\
{[0.141]}\end{array}$ & & $\begin{array}{l}2.587 \\
{[0.399]}\end{array}$ & $\begin{array}{l}2.969 \\
{[0.342]}\end{array}$ & $\begin{array}{l}0.706 \\
{[0.462]}\end{array}$ & & $\begin{array}{l}0.261 \\
{[0.774]}\end{array}$ & $\begin{array}{l}0.437 \\
{[0.649]}\end{array}$ \\
\hline Average_INF * Developed ${ }^{5}$ & $\begin{array}{l}-2.322^{\star *} \\
{[0.043]}\end{array}$ & & & $\begin{array}{l}-2.579 \star \star \\
{[0.030]}\end{array}$ & $\begin{array}{l}-1.790 \\
{[0.106]}\end{array}$ & & & $\begin{array}{l}-2.132^{\star} \\
{[0.063]}\end{array}$ \\
\hline Average_INF * Less_Developed ${ }^{5}$ & $\begin{array}{l}-0.216 \\
{[0.770]}\end{array}$ & & & $\begin{array}{l}0.250 \\
{[0.750]}\end{array}$ & $\begin{array}{l}-0.614 \\
{[0.293]}\end{array}$ & & & $\begin{array}{l}-0.377 \\
{[0.537]}\end{array}$ \\
\hline PARTY ${ }^{6}$ & & $\begin{array}{l}2.140 \star \star \star \\
{[0.002]}\end{array}$ & $\begin{array}{l}1.811^{\star \star \star} \\
{[0.005]}\end{array}$ & $\begin{array}{l}2.012^{\star \star \star} \\
{[0.003]}\end{array}$ & & $\begin{array}{l}1.846^{\star \star \star} \\
{[0.000]}\end{array}$ & $\begin{array}{l}1.708^{\star \star \star} \\
{[0.000]}\end{array}$ & $\begin{array}{l}1.791^{\star \star \star} \\
{[0.000]}\end{array}$ \\
\hline VOTES $^{7}$ & & $\begin{array}{l}1.557^{\star *} \\
{[0.045]}\end{array}$ & $\begin{array}{l}1.426^{*} \\
{[0.061]}\end{array}$ & $\begin{array}{l}1.451^{*} \\
{[0.059]}\end{array}$ & & $\begin{array}{l}1.456^{\star \star *} \\
{[0.005]}\end{array}$ & $\begin{array}{l}1.397^{\star \star \star} \\
{[0.007]}\end{array}$ & $\begin{array}{l}1.444^{\star \star *} \\
{[0.006]}\end{array}$ \\
\hline Developed Countries & $\begin{array}{l}1.314^{\star \star \star} \\
{[0.001]}\end{array}$ & $\begin{array}{l}1.787^{\star \star \star} \\
{[0.000]}\end{array}$ & $\begin{array}{l}0.995^{\star \star} \\
{[0.013]}\end{array}$ & $\begin{array}{l}1.317^{\star \star \star} \\
{[0.003]}\end{array}$ & $\begin{array}{l}0.994^{\star \star \star} \\
{[0.002]}\end{array}$ & $\begin{array}{l}1.156^{\star \star \star} \\
{[0.003]}\end{array}$ & $\begin{array}{l}0.727^{\star \star} \\
{[0.020]}\end{array}$ & $\begin{array}{l}0.857^{* *} \\
{[0.013]}\end{array}$ \\
\hline New Democracies & $\begin{array}{l}0.743^{\star \star \star} \\
{[0.005]}\end{array}$ & $\begin{array}{l}0.663^{\star \star} \\
{[0.025]}\end{array}$ & $\begin{array}{l}0.442 \\
{[0.116]}\end{array}$ & $\begin{array}{l}0.641^{\star \star} \\
{[0.036]}\end{array}$ & $\begin{array}{l}0.373^{\star} \\
{[0.064]}\end{array}$ & $\begin{array}{l}0.323 \\
{[0.144]}\end{array}$ & $\begin{array}{l}0.194 \\
{[0.366]}\end{array}$ & $\begin{array}{l}0.316 \\
{[0.160]}\end{array}$ \\
\hline Majoritarian Electoral System & $\begin{array}{l}0.522^{\star *} \\
{[0.013]}\end{array}$ & $\begin{array}{l}0.479 * \star \\
{[0.036]}\end{array}$ & $\begin{array}{l}0.414^{\star} \\
{[0.062]}\end{array}$ & $\begin{array}{l}0.429^{*} \\
{[0.059]}\end{array}$ & $\begin{array}{l}0.415^{\star \star} \\
{[0.017]}\end{array}$ & $\begin{array}{l}0.310 \\
{[0.105]}\end{array}$ & $\begin{array}{l}0.310^{\star} \\
{[0.099]}\end{array}$ & $\begin{array}{l}0.284 \\
{[0.137]}\end{array}$ \\
\hline Constant & $\begin{array}{l}-1.216^{\star \star \star} \\
{[0.000]}\end{array}$ & $\begin{array}{l}-2.311^{\star \star *} \\
{[0.000]}\end{array}$ & $\begin{array}{l}-1.833^{\star \star \star} \\
{[0.000]}\end{array}$ & $\begin{array}{l}-2.060^{\star \star \star} \\
{[0.000]}\end{array}$ & $\begin{array}{l}-1.100^{\star \star \star} \\
{[0.000]}\end{array}$ & $\begin{array}{l}-1.797^{\star \star \star} \\
{[0.000]}\end{array}$ & $\begin{array}{l}-1.710^{\star \star \star} \\
{[0.000]}\end{array}$ & $\begin{array}{l}-1.720^{\star \star \star} \\
{[0.000]}\end{array}$ \\
\hline Pseudo $\mathrm{R}^{2}$ & 0.147 & 0.178 & 0.149 & 0.164 & 0.125 & 0.164 & 0.146 & 0.154 \\
\hline Akaike's criteria & 337.50 & 309.12 & 316.81 & 315.66 & 450.53 & 412.84 & 419.27 & 419.30 \\
\hline Schwartz's criteria & 401.25 & 375.10 & 379.31 & 385.10 & 519.82 & 485.03 & 487.66 & 495.28 \\
\hline Observations & 255 & 238 & 238 & 238 & 347 & 330 & 330 & 330 \\
\hline
\end{tabular}

${ }^{1}$ For variables definitions see Appendix I. The figures in the table are probit coefficients and the figures in the parantheses are P-values. An asterisk $\left({ }^{*}\right)$ indicates multiplication by the binary variable that follows. developed - A binary variable with a value of 1 for developed countries, less_developed - A binary variable with a value of 1 for less developed countries.

${ }^{2}$ REVCH_term - The change in the ratio of the government revenue to GDP in the two years preceding the election year, relative to the two previous yearsEXPCH_term - The change in the ratio of the government expenditure to GDP in the two years preceding the election year, relative to the two previous years. $\mathbf{R E V C H}$ ey -The change in the government revenue ratio to GDP In the election year, compared to the previous year. EXPCH ey -The change in the government expenditure ratio to GDP In the election year, compared to the previous year. GDPPC_gr - The average growth rate of real per-capita GDP during the leader's current term.

${ }^{3}$ INF_ey - The inflation rate in the election year.

${ }^{4}$ INFCH_ey - The increase in the inflation rate from the year preceding the election year to the election year.

${ }^{5}$ Average_INF - The average rate of inflation rate during the leader's current term.

${ }^{6}$ PARTY - The percent of seats in the parliament held by the leader's party, receives the value 0 in a presidential system.

${ }^{7}$ VOTES - The percent of the votes received by a leader in a presidential system in the first round of the previous elections.

* - Significant at the 10 percent level; ** - Significant at the 5 percent level; ** - Significant at the 1 percent level. 